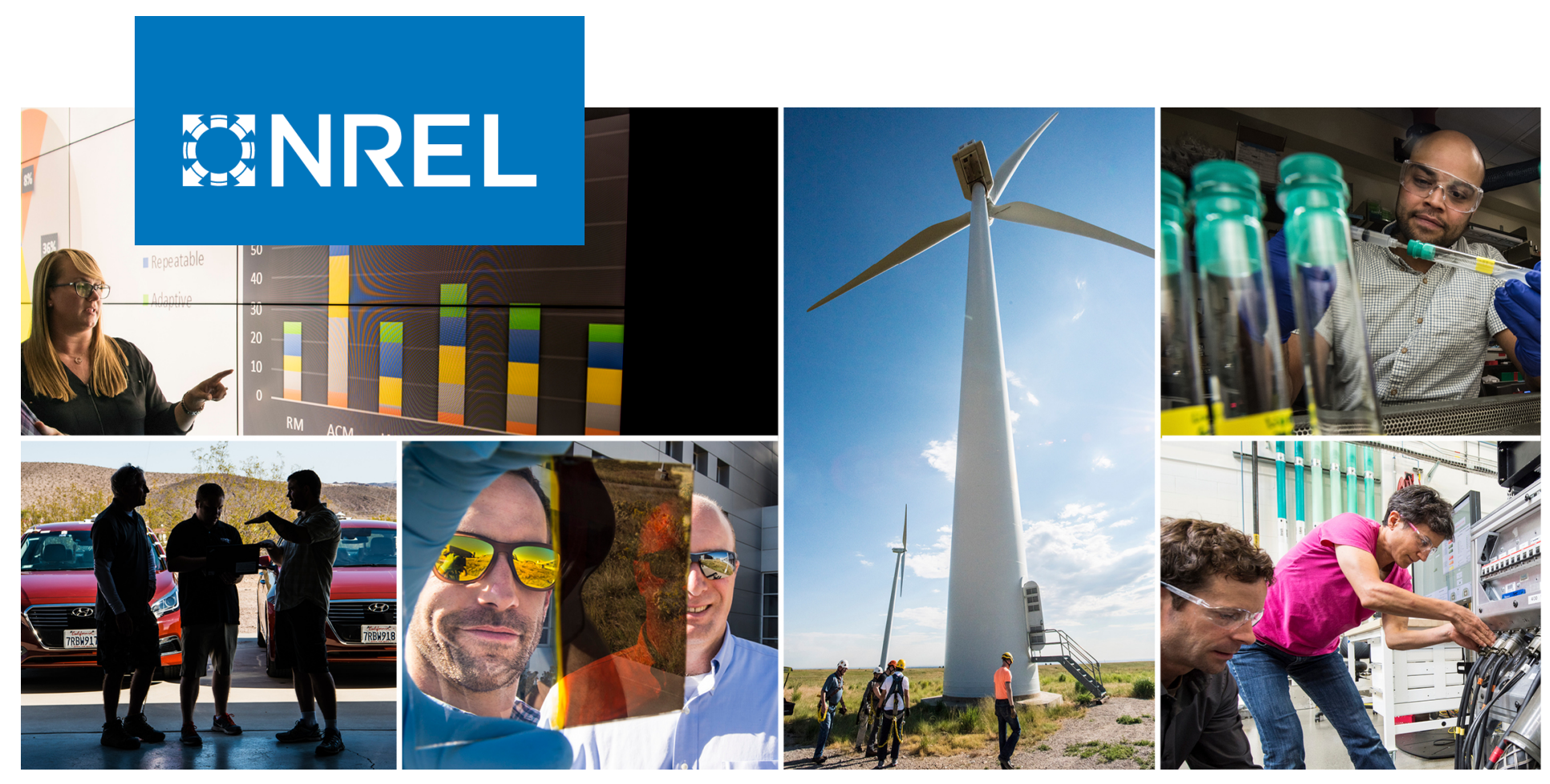

\title{
REopt Lite User Manual
}

Kate Anderson, Dan Olis, Bill Becker, Linda Parkhill, Nick Laws, Xiangkun Li, Sakshi Mishra, Ted Kwasnik, Andrew Jeffery, Emma Elgqvist, Kathleen Krah, Dylan Cutler, Alex Zolan, Nick Muerdter, Rob Eger, Andy Walker, Chris Hampel, and Gregg Tomberlin

National Renewable Energy Laboratory

NREL is a national laboratory of the U.S. Department of Energy Office of Energy Efficiency \& Renewable Energy

Operated by the Alliance for Sustainable Energy, LLC

This report is available at no cost from the National Renewable Energy Laboratory (NREL) at www.nrel.gov/publications.
Technical Report

NREL/TP-7A40-79235

March 2021 


\section{ENREL}

\section{REopt Lite User Manual}

Kate Anderson, Dan Olis, Bill Becker, Linda Parkhill, Nick Laws, Xiangkun Li, Sakshi Mishra, Ted Kwasnik, Andrew Jeffery, Emma Elgqvist, Kathleen Krah, Dylan Cutler, Alex Zolan, Nick Muerdter, Rob Eger, Andy Walker, Chris Hampel, and Gregg Tomberlin

National Renewable Energy Laboratory

\section{Suggested Citation}

Anderson, Kate, Dan Olis, Bill Becker, Linda Parkhill, Nick Laws, Xiangkun Li, Sakshi Mishra, Ted Kwasnik, Andrew Jeffery, Emma Elgqvist, Kathleen Krah, Dylan Cutler, Alex Zolan, Nick Muerdter, Rob Eger, Andy Walker, Chris Hampel, and Gregg Tomberlin. 2021. REopt Lite User Manual. Golden, CO: National Renewable Energy Laboratory. NREL/TP-7A40-79235. https://www.nrel.gov/docs/fy21osti/79235.pdf.

NREL is a national laboratory of the U.S. Department of Energy Office of Energy Efficiency \& Renewable Energy Operated by the Alliance for Sustainable Energy, LLC

This report is available at no cost from the National Renewable Energy Laboratory (NREL) at www.nrel.gov/publications.

Contract No. DE-AC36-08GO28308
Technical Report NREL/TP-7A40-79235 March 2021

National Renewable Energy Laboratory 15013 Denver West Parkway Golden, CO 80401 303-275-3000 • www.nrel.gov 


\section{NOTICE}

This work was authored by the National Renewable Energy Laboratory, operated by Alliance for Sustainable Energy, LLC, for the U.S. Department of Energy (DOE) under Contract No. DE-AC36-08GO28308. Funding provided by the U.S. Department of Energy Office of Energy Efficiency and Renewable Energy Advanced Manufacturing Office. The views expressed herein do not necessarily represent the views of the DOE or the U.S. Government.

This report is available at no cost from the National Renewable Energy Laboratory (NREL) at www.nrel.gov/publications.

U.S. Department of Energy (DOE) reports produced after 1991 and a growing number of pre-1991 documents are available free via www.OSTI.gov.

Cover Photos by Dennis Schroeder: (clockwise, left to right) NREL 51934, NREL 45897, NREL 42160, NREL 45891, NREL 48097, NREL 46526.

NREL prints on paper that contains recycled content. 


\section{Acknowledgments}

We gratefully acknowledge the many people whose efforts contributed to this report. The REopt Lite $^{\mathrm{TM}}$ model is based on the National Renewable Energy Laboratory's (NREL's) REopt ${ }^{\mathrm{TM}}$ model, which has benefited from the expertise of many contributors and advisors over the years. We thank the vast number of current and past NREL employees on and beyond the REopt team who have contributed to data and model development, testing, and analysis, especially Nick DiOrio and Josiah Pohl. We also thank Alexandra Newman and Rob Braun of Colorado School of Mines for their contributions to optimization model development and the combined heat and power module. The model has been improved through the guidance and review provided by Nate Blair, Craig Christensen, Ben Polly, Ben Sigrin, Jie Zhang, Moncef Krarti, Rob Braun, Robert Brigantic, Tim McDowell, Mike Coddington, and Adam Warren, as well as the U.S. Department of Energy (DOE) REopt Lite Advisory Board. We are grateful to all those who helped sponsor REopt Lite development and analysis, especially Rachel Shepherd of the DOE Office of Energy Efficiency and Renewable Energy Federal Energy Management Program and Bob Gemmer of the DOE Advanced Manufacturing Office. 


\section{List of Acronyms}

AC

AMO

AOP

API

AVERT

CAPEX

CBI

CHP

$\mathrm{CO} 2$

$\mathrm{CO} 2 \mathrm{e}$

COP

CRB

DC

DER

DOE

EIA

EPA

ESPC

HHV

IRR

ISO

ITC

LID

MACRS

NIST

NREL

O\&M

PBI

PPA

PV

SAM

SOC

T\&D

TES

UESC

URDB

WIND alternating current

Advanced Manufacturing Office

annual operating plan

Application Programming Interface

AVoided Emissions and geneRation Tool

capital expenditure

capital cost-based incentives

combined heat and power

carbon dioxide

carbon dioxide equivalent

coefficient of performance

Commercial Reference Building

direct current

distributed energy resource

Department of Energy

Energy Information Administration

Environmental Protection Agency

energy savings performance contract

higher heating value

internal rate of return

International Organization for Standardization

investment tax credit

light-induced degradation

Modified Accelerated Cost Recovery System

National Institute of Standards and Technology

National Renewable Energy Laboratory

operations and maintenance

production-based incentive

power purchase agreement

solar photovoltaics

System Advisor Model

state of charge

transmission and distribution

thermal energy storage

utility energy service contract

Utility Rate Database

Wind Integration National Dataset 


\section{Executive Summary}

REopt Lite evaluates the economic viability of grid-connected solar photovoltaics, wind, combined heat and power, and electric and thermal storage at commercial and small industrial sites. It allows building owners to identify the system sizes and dispatch strategies that minimize the site's life cycle cost of energy. REopt Lite also estimates the amount of time on-site generation and storage can sustain the site's critical load during a grid outage and allows the user the choice of optimizing for energy resilience. It is primarily used to inform project development decisions and to support research on the factors that drive project feasibility for market development and policy analysis. It is available through a web interface, application programing interface, and open-source code.

This user manual provides an overview of the model, including its capabilities and typical applications; inputs and outputs; economic calculations; technology descriptions; and model parameters, variables, and equations. The model is highly flexible and is continually evolving to meet the needs of each analysis. Therefore, this report is not an exhaustive description of all capabilities, but rather a summary of the core components of the model. Tutorials that guide users through the tool inputs and results are available here: https://reopt.nrel.gov/userguides.html. 


\section{Table of Contents}

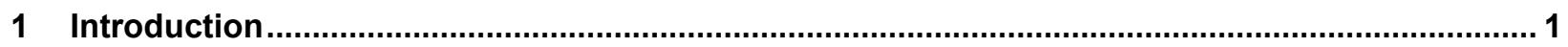

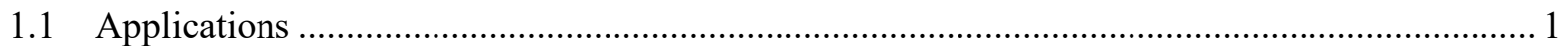

1.1.1 What Questions Does REopt Lite Answer? ............................................................ 2

1.1.2 What Questions Does REopt Lite NOT Answer? .................................................... 2

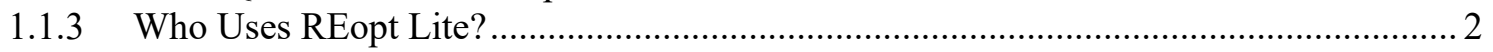

1.1.4 How Does REopt Lite Compare with Other Models? .............................................. 3

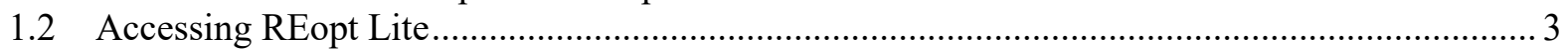

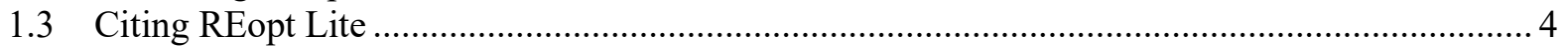

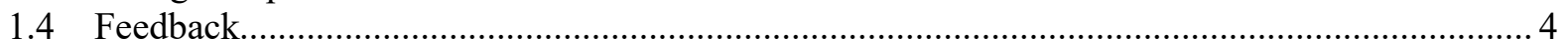

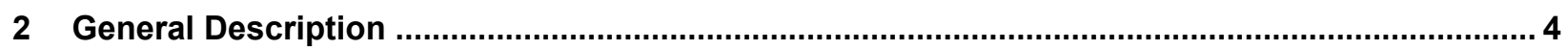

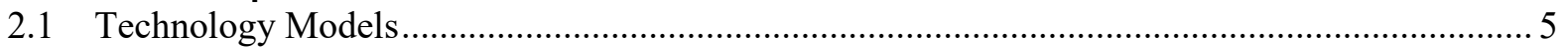

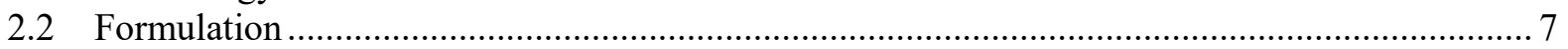

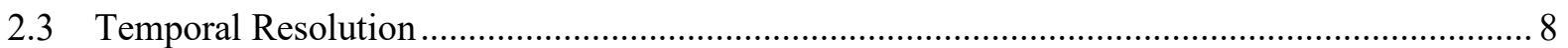

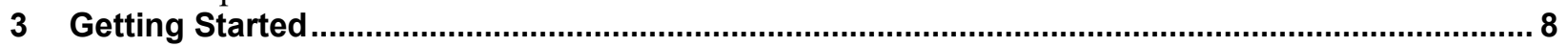

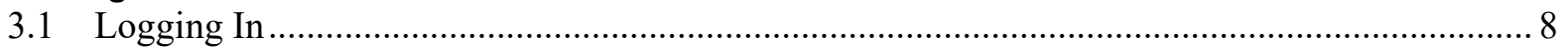

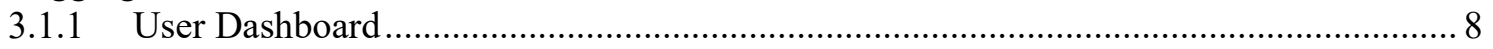

3.1.2 Custom Load Profiles.......................................................................... 9

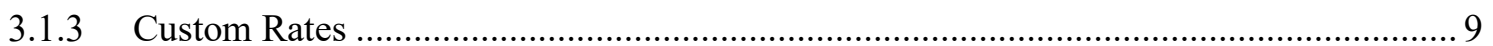

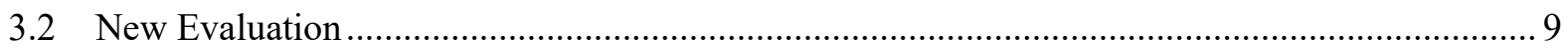

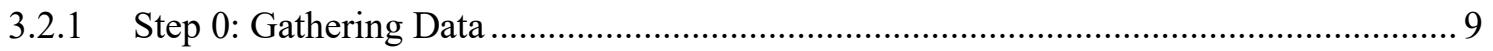

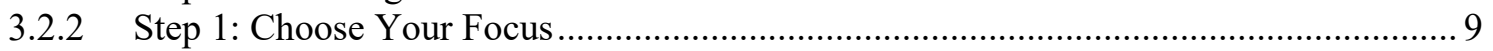

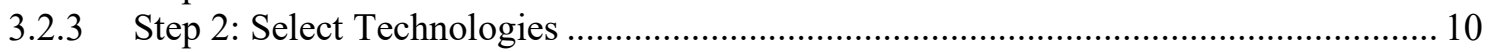

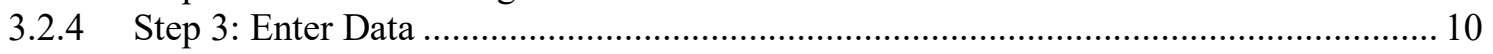

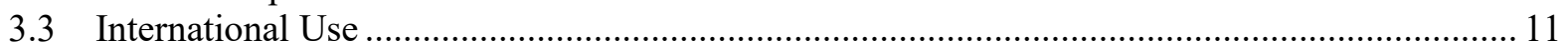

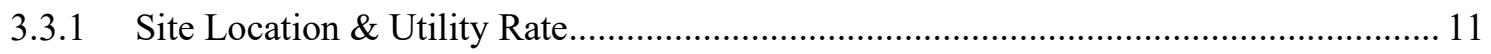

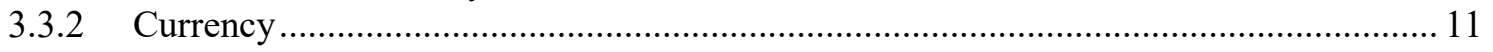

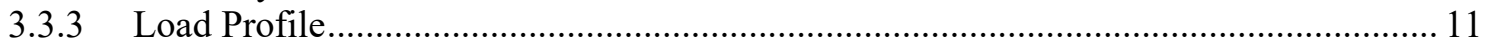

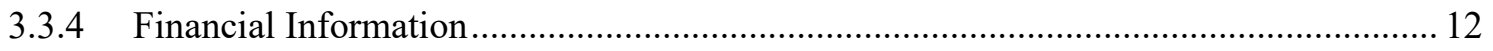

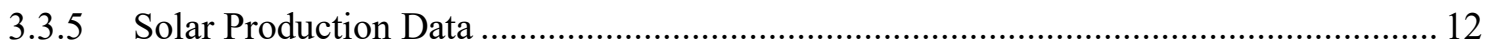

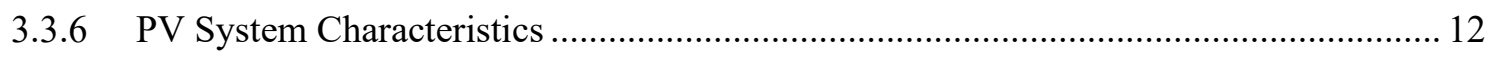

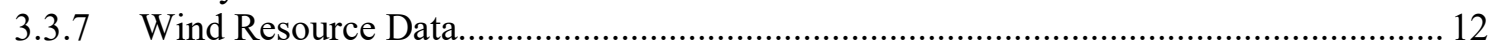

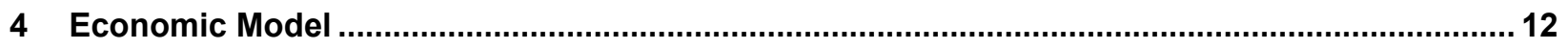

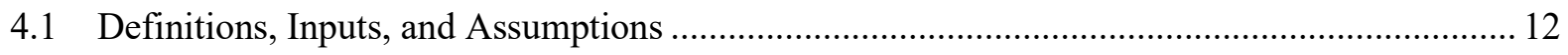

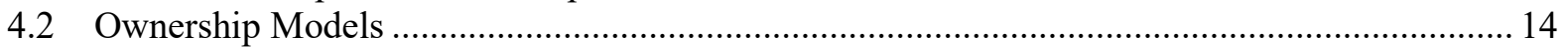

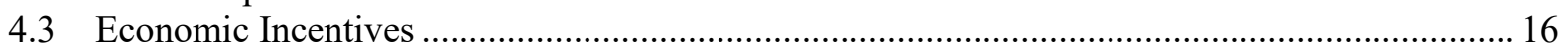

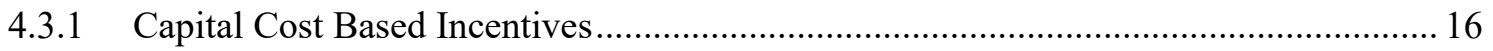

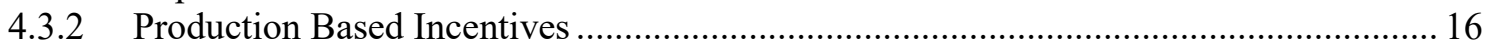

4.3.3 Modified Accelerated Cost Recovery System............................................................ 16

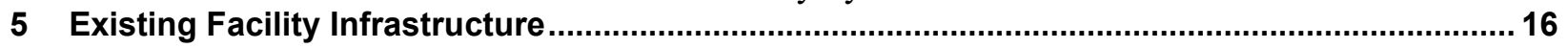

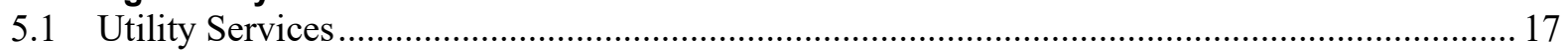

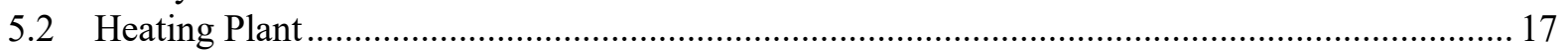

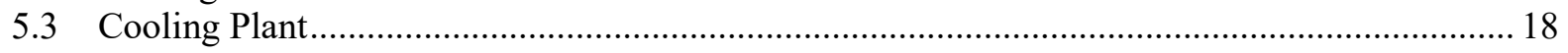

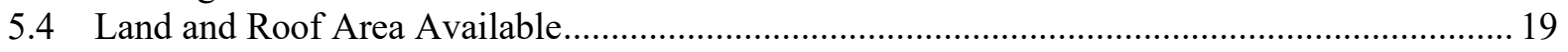

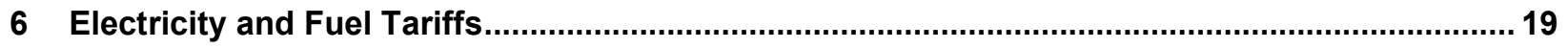

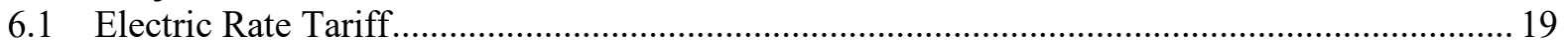

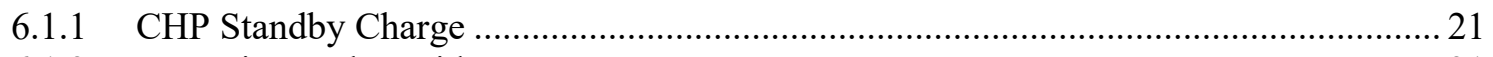

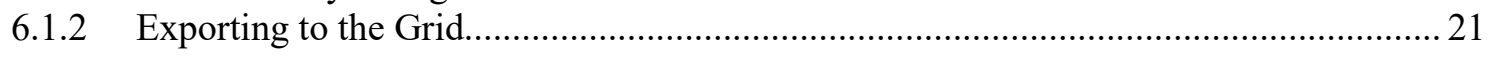

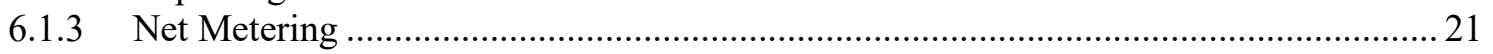

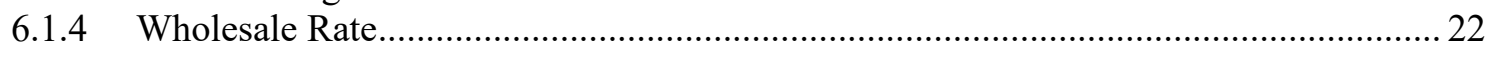




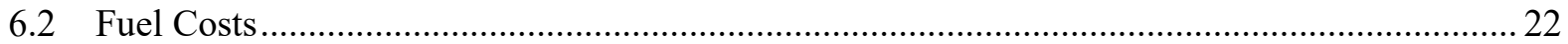

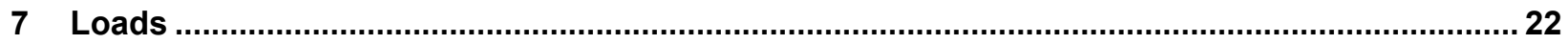

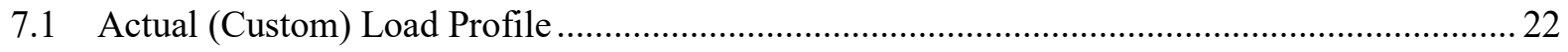

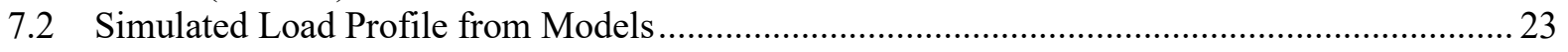

7.2.1 Modeling a Campus with Multiple Simulated Building Load Profiles ......................... 25

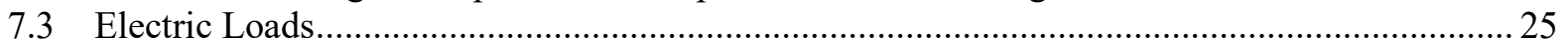

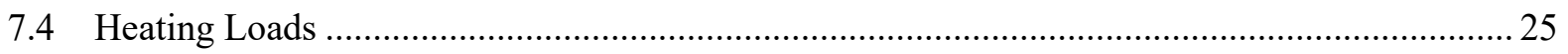

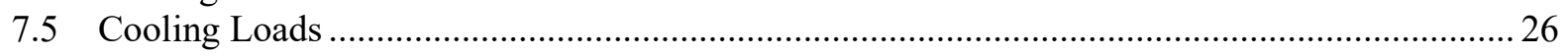

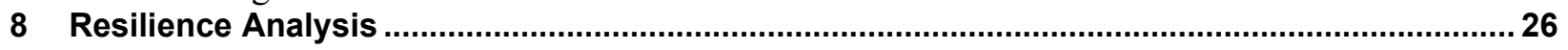

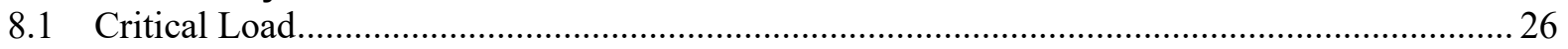

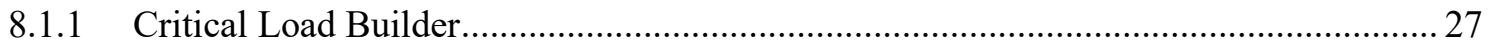

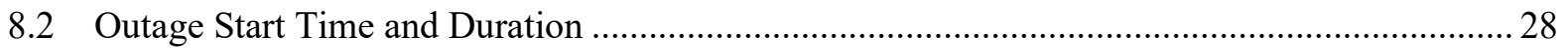

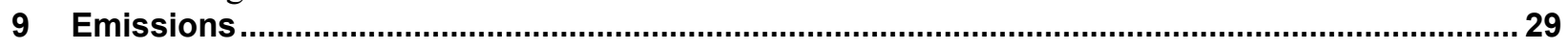

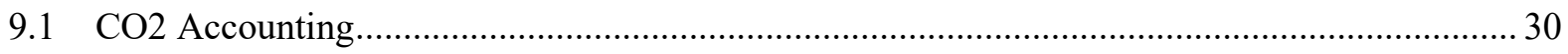

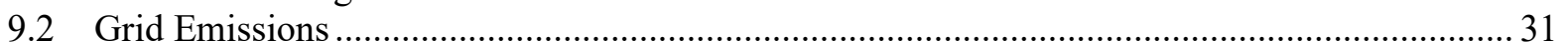

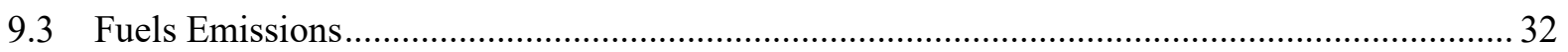

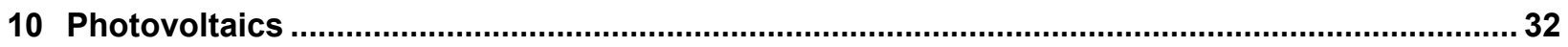

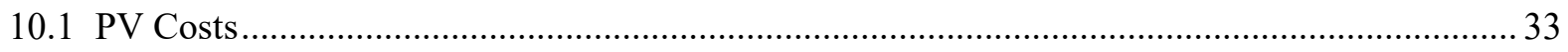

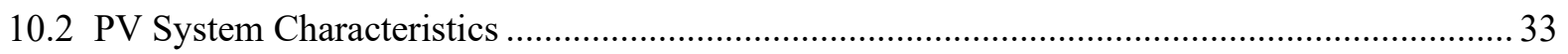

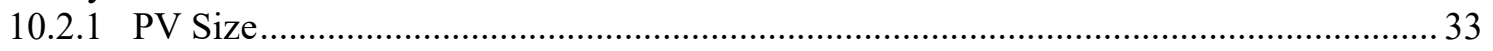

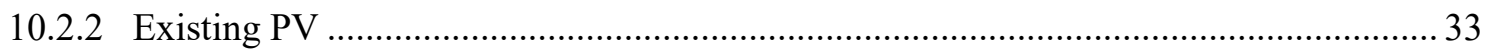

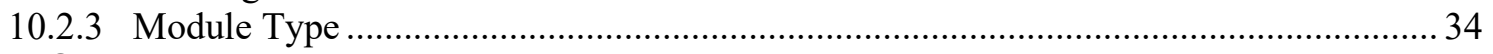

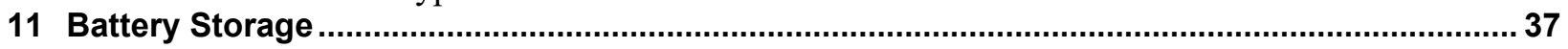

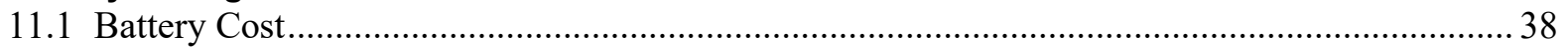

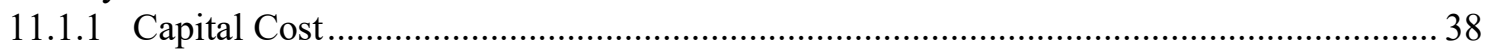

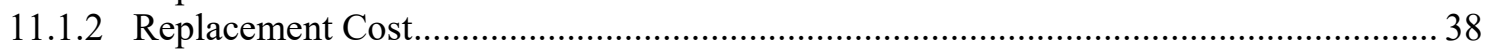

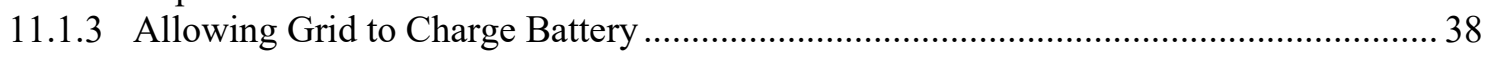

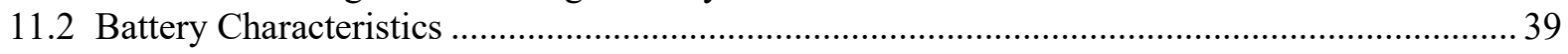

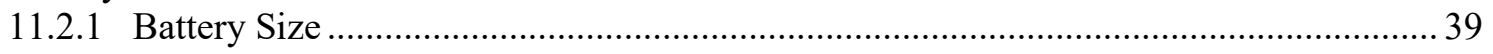

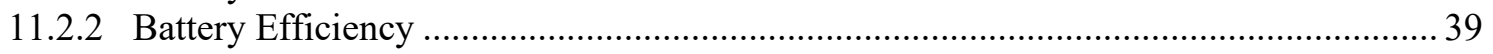

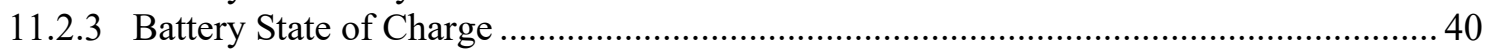

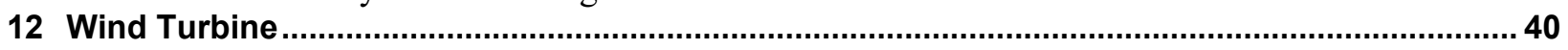

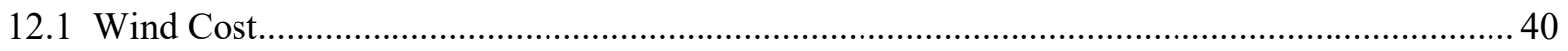

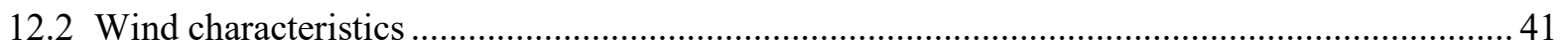

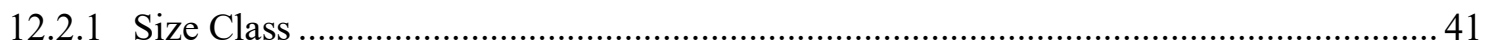

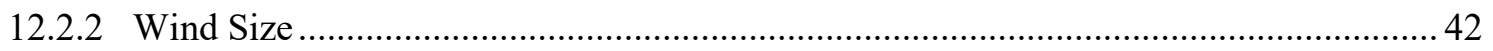

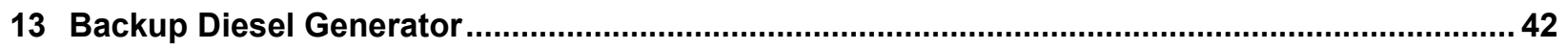

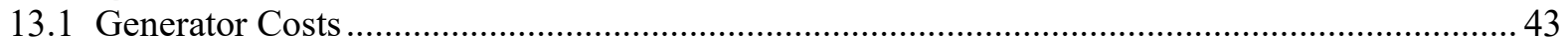

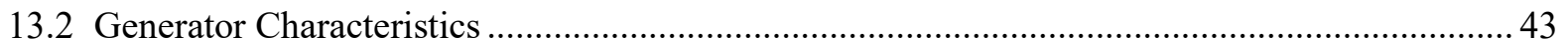

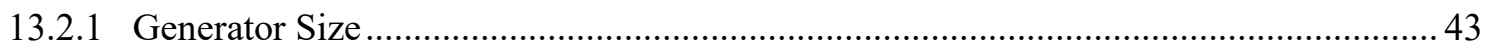

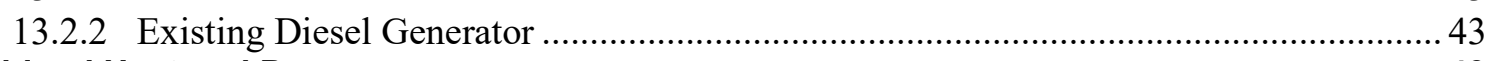

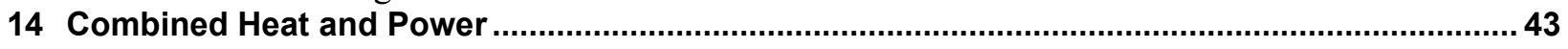

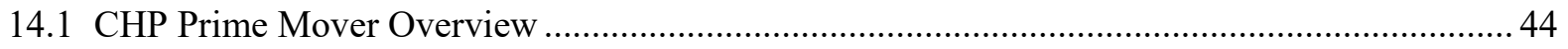

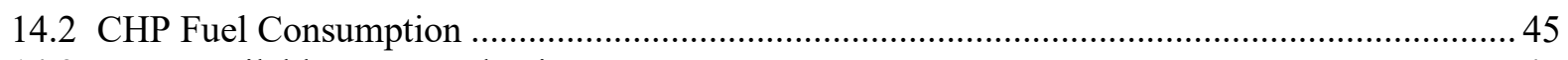

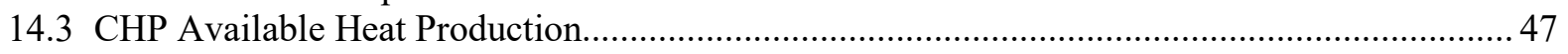

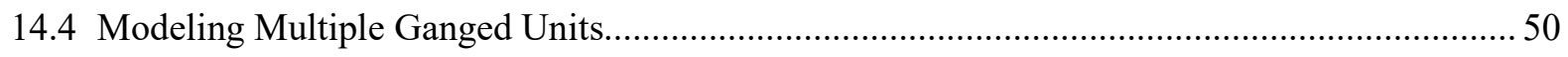

14.5 Combustion Turbine Supplementary Duct Firing …........................................................... 52

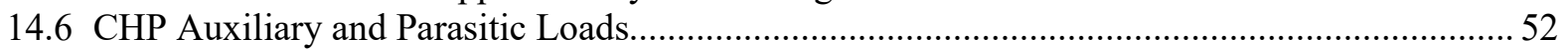

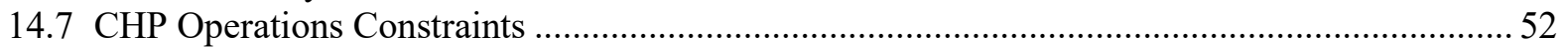

14.8 Default CHP Cost and Performance Parameters by Prime Mover Type and Size Class ............ 52

14.9 CHP Scheduled and Unscheduled Maintenance ….............................................................. 57

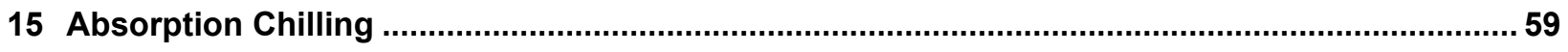




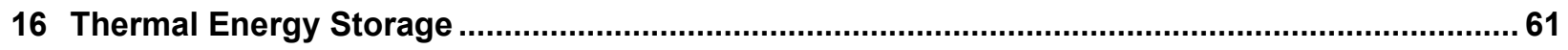

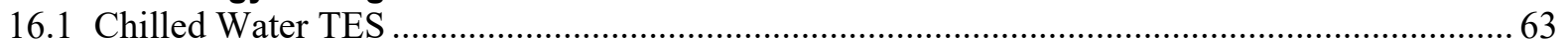

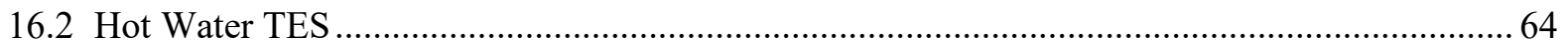

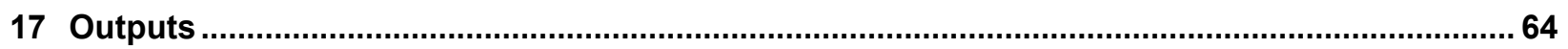

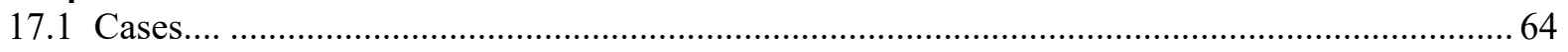

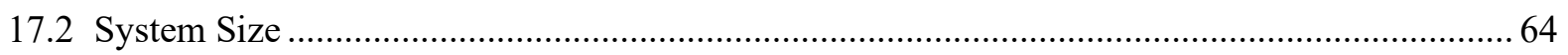

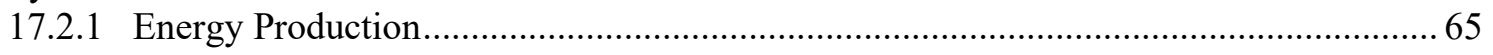

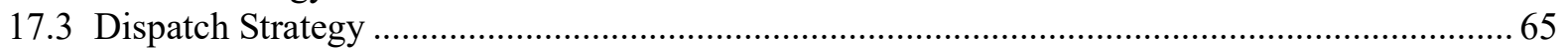

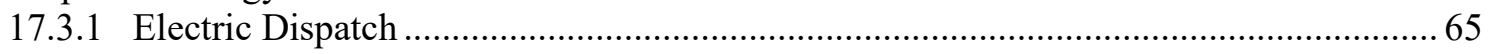

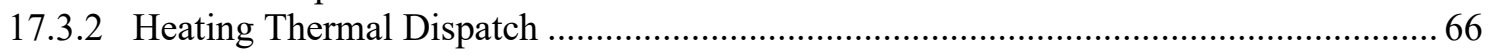

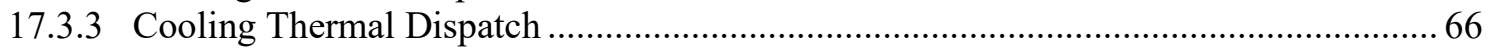

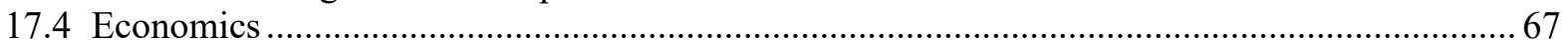

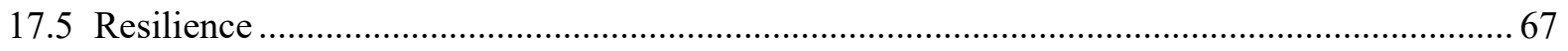

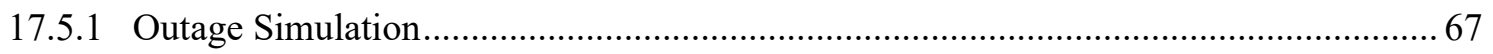

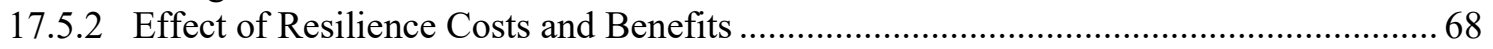

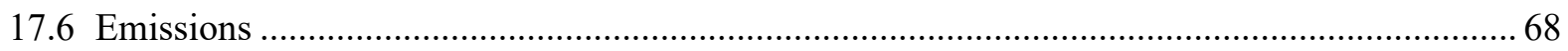

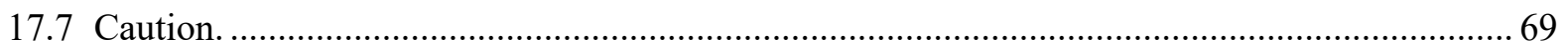

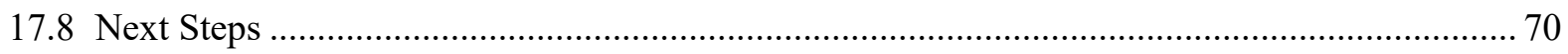

18 REopt Lite Default Values, Typical Ranges, and Sources ................................................... 71

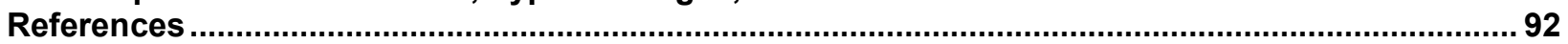

Appendix A: CHP Cost and Performance Data by Prime Mover Type and Size Class ..................... 94

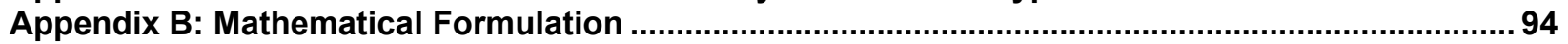




\section{List of Figures}

Figure 1. System diagram for REopt Lite power, heating, and cooling technologies and loads ................ 6

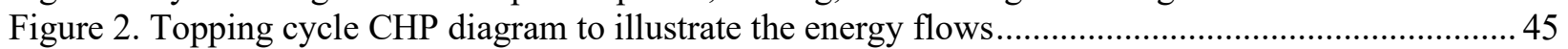

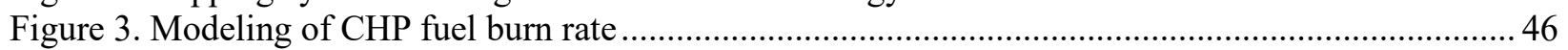

Figure 4. Modeling of CHP available useful heat............................................................................ 48

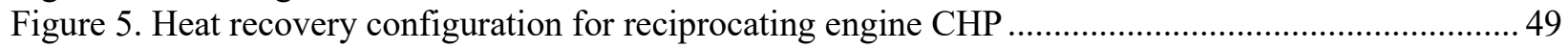

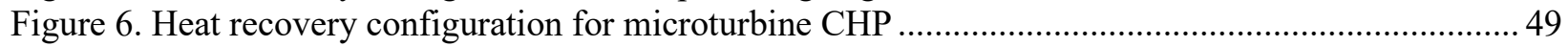

Figure 7. Heat recovery configuration for combustion turbine CHP .............................................. 50

Figure 8. Fuel consumption and electrical efficiency versus load for one $200-\mathrm{kW}$ microturbine ............... 51

Figure 9. Actual and REopt-modeled fuel and electrical efficiency curves for three $200-\mathrm{kW}$ generators

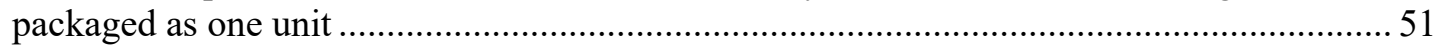

Figure 10. Example month for understanding how to build a maintenance period with respect to the

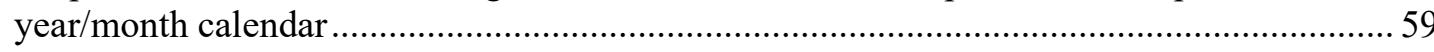

Figure 11. TES installed cost estimates from Glazer (2019) and applying a $14^{\circ} \mathrm{F}$ temperature differential

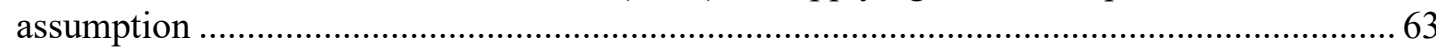

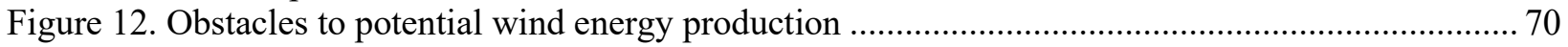

\section{List of Tables}

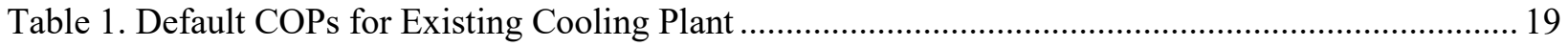

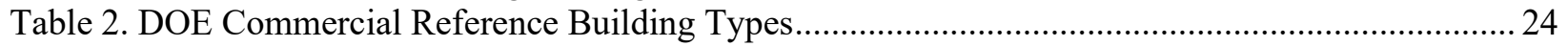

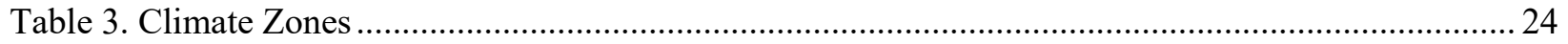

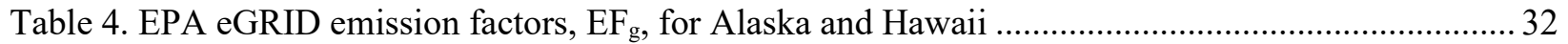

Table 5. Selected Fuel-Specific Energy and CO2 Emissions Factors..................................................... 32

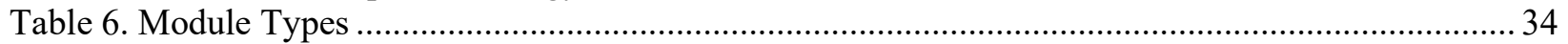

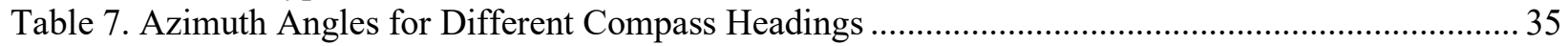

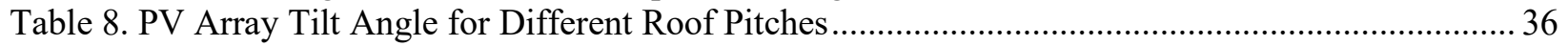

Table 9. Default Values for the System Loss Categories........................................................................ 37

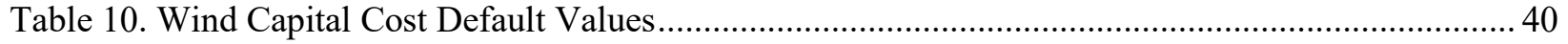

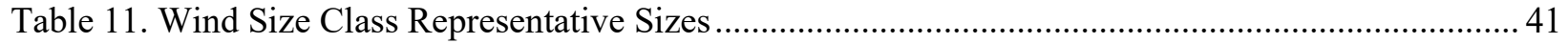

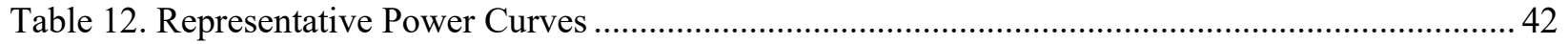

Table 13. Threshold of Average Boiler Fuel Load over which the Default Prime Mover Switches from

Reciprocating Engine to Combustion Turbine .................................................................... 53

Table 14. Reciprocating Engine Cost and Performance Parameters Included in REopt Lite .................... 55

Table 15. Micro-Turbine Cost and Performance Parameters Included in REopt Lite............................... 56

Table 16. Combustion Turbine Cost and Performance Parameters Included in REopt Lite.......................57

Table 17. Default Maintenance Periods and Unavailability Summary Metrics.........................................58

Table 18. Custom Uploaded CHP Maintenance Schedule Form Description .........................................58

Table 19. Site and Utility Inputs, Default Values, Ranges, and Sources ................................................ 71

Table 20. Load Profile Inputs, Default Values, Ranges, and Sources .................................................... 72

Table 21. Financial Inputs, Default Values, Ranges, and Sources........................................................... 72

Table 22. Emissions Inputs, Default Values, Ranges, and Sources ................................................... 75

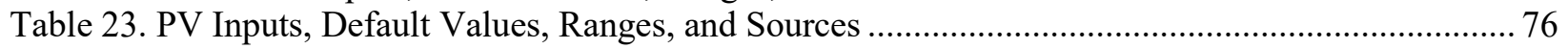

Table 24. Battery Storage Inputs, Default Values, Ranges, and Sources ............................................ 82

Table 25. Wind Inputs, Default Values, Ranges, and Sources .............................................................. 86

Table 26. Resilience Evaluations- Load Profile Inputs, Default Values, Ranges, and Sources................. 88

Table 27. Resilience Evaluations- Generator Inputs, Default Values, Ranges, and Sources...................... 88

Table 28. Combined Heat and Power Inputs, Default Values, Ranges, and Sources ............................... 90

Table 29. Hot Water Storage Inputs, Default Values, Ranges, and Sources ........................................... 91 
Table 30. Absorption Chilling Inputs, Default Values, Ranges, and Sources ......................................... 92

Table 31. Chilled Water Storage Inputs, Default Values, Ranges, and Sources. 


\section{Introduction}

The REopt Lite ${ }^{\mathrm{TM}}$ web tool evaluates the economic viability of grid-connected solar photovoltaics (PV), wind, combined heat and power (CHP), and storage at commercial and small industrial sites. It allows building owners to identify the system sizes and dispatch strategies that minimize the site's life cycle cost of energy. REopt Lite also estimates the amount of time onsite generation and storage can sustain the site's critical load during a grid outage and allows the user the choice of optimizing for energy resilience.

REopt Lite allows users to screen the technical and economic potential of distributed energy technologies on their own or in combination with each other. The user can select default performance parameters or enter user-specified performance parameters that are consistent with the model architecture and assumptions. By default, technology sizes will be determined by the model although the user can instead specify a size to be evaluated within a predetermined range.

Users are cautioned that although this model provides an estimate of the techno-economic feasibility of PV, wind, CHP, and storage installations, this is not a design tool. The results are indicative of a potential opportunity; they do not describe a design for procurement. Investment decisions should not be made based on these results alone.

This report primarily describes access of REopt Lite through the web-interface, or user-interface, although some specific features only accessible via the application programming interface (API) are occasionally described. Tutorials that guide users through the tool inputs and results are available here: https://reopt.nrel.gov/user-guides.html.

\subsection{Applications}

Although a variety of potential applications are possible, REopt Lite is primarily designed to address two use cases:

- Project development decision support: REopt Lite is used to evaluate the technical and economic feasibility of PV, wind, CHP, and storage projects early in the project development process. In a typical development process, sites are qualified using an iterative analysis approach employing increasing levels of rigor and detail around key input assumptions with each successive iteration. This approach is designed to identify potential fatal flaws as quickly as possible and with a minimum of effort and expense. REopt Lite can be used for early screenings that rely on minimal site information. The default assumptions for many parameters, such as modeled building loads and industry average cost data, are sufficient for this initial screening. Projects without obvious flaws are reanalyzed using increasing levels of actual site- and technology-specific information. In this case, many of the default assumptions may be overridden with specific values based on more detailed investigation and qualification of the site.

- Research-related uses: REopt Lite is used to research the general conditions and factors driving project feasibility for market development and policy analysis. For example, the tool can be used to explore combinations of technology cost and incentive support needed for project feasibility on different building types and under different tariff structures. 


\subsubsection{What Questions Does REopt Lite Answer?}

REopt Lite is used to evaluate the economics and resilience benefits of behind-the-meter distributed energy resources (DER) at specific sites. REopt Lite answers questions such as:

- What type and size of DERs should I install to minimize my cost of energy?

- How much will it cost to achieve a sustainability goal?

- What is the most cost-effective way to survive a grid outage spanning one day? Three days? One week?

- Where do market opportunities exist for DERs, now and in the future?

- How do I optimize system control across multiple value streams to maximize project value?

\subsubsection{What Questions Does REopt Lite NOT Answer?}

REopt Lite is not used to answer questions about:

- Front-of-the-meter or utility projects. REopt Lite is designed to model the economics of DER at specific sites, behind the utility meter. It models opportunities to reduce utility bills through demand reduction and energy arbitrage. It does not capture front-of-the-meter value streams like demand response, frequency regulation, or ancillary services.

- Regional or national energy adoption. REopt Lite is not used to predict adoption of energy technologies across city, regional, or national-scale systems.

- Off-grid sites. While users can specify a grid outage that lasts a full year, effectively modeling an off-grid site, REopt Lite does not take into account important considerations for off-grid energy systems like reserve requirements.

- Power flow. REopt Lite is an energy-balance model. It does not consider power flow characteristics.

- Detailed design. This is not a design tool. The results are indicative of a potential opportunity; they do not describe a design for procurement. The model generates the economic outlook for potential distributed energy technologies to identify whether they may be worth further consideration with more detailed assessment and consultation with professional engineers.

- Building energy modeling. Loads to be served by DER are inputs to REopt Lite; it does not include building energy modeling.

While the REopt Lite web tool is not designed to answer the questions above, researchers are continually adapting the Application Programming Interface (API) and open source code as well as integrating REopt Lite with other models to address emerging research questions.

\subsubsection{Who Uses REopt Lite?}

The REopt Lite web tool is accessible to users with a range of skill levels and data. Inputs are configured so that increasingly detailed input options are progressively exposed to users. Basic users, or those with minimal data, will enter minimal site-specific information to run an analysis. Results will provide an initial, high-level assessment of project feasibility at a site. Advanced analyses will use detailed site information (e.g., exact tariffs, actual load profiles, actual site area and roof space available) to produce results with a higher degree of accuracy. 
REopt Lite is used by:

- Building owners, energy managers, and energy consultants to understand the economics and resilience benefits of DER at their site

- Developers to understand the economics of DER across a range of potential sites

- Utilities to understand the economics of DER at their customers' sites

- Industry to understand optimal control strategies for DER

- Researchers to understand economics and resilience benefits of integrated suites of DER.

\subsubsection{How Does REopt Lite Compare with Other Models?}

Other models that also evaluate the technical and economic viability of distributed energy at the site level include RETScreen, System Advisor Model, HOMER, DER-CAM, EnergyPro, TRNSYS, iHOGA, eSyst and ficus. The unique features of REopt Lite include:

- Optimization: REopt Lite optimizes system size and dispatch strategy (the user does not have to enter the size/dispatch)

- Integration: REopt Lite assesses an integrated suite of electric and thermal technologies (rather than each technology individually)

- Accessibility: REopt Lite is accessible to novice users with just three required inputs while also offering over 100 optional inputs and an API and open-source code for advanced users

- Transparency and Extendibility: REopt Lite provides transparency into the model formulation and extendibility of the code through the open-source model.

\subsection{Accessing REopt Lite}

REopt Lite is available in three formats:

- Web interface: reopt.nrel.gov/tool. The web interface allows users to easily input data, run analysis, and view results for a single site in a graphical user interface.

- API: https://developer.nrel.gov/docs/energy-optimization/reopt-v1/. The API allows users and software developers to programmatically interface with the REopt Lite web tool. The API can be used to evaluate multiple sites and perform sensitivity analyses in an efficient manner, and to integrate REopt Lite capabilities into other tools. The REopt Lite API is available on the NREL developer network. Nonprofit or commercial use of these web services is free, subject to hourly and daily limits on the number of web service requests as described at developer.nrel.gov/docs/rate-limits.

- Open source: https:/github.com/NREL/REopt_Lite_API. The open-source code allows software developers to modify the REopt Lite code or host it on their own servers. It is licensed under BSD-3, a permissive license that allows for modification and distribution for private and commercial use.

REopt Lite is a free, publicly available web version of the more comprehensive REopt model, which is described in Cutler et al. (2017). The full REopt model is not available outside NREL. The full model includes technologies that are not yet available in REopt Lite such as solar hot water, solar ventilation preheating, and geothermal heat pumps. NREL is gradually transitioning capabilities from the internal version to the public REopt Lite version as time and funding allow. 


\subsection{Citing REopt Lite}

To cite REopt Lite analysis results for a specific site, please use:

NREL. [Year]. "REopt Lite Results from [Site Location], [Technologies] [Financial or Resilience] Evaluation." REopt Lite Web Tool. Accessed [Month Day, Year]. [URL].

For example:

NREL. 2020. "REopt Lite Results from Palmdale, CA, PV and Battery Storage Financial Evaluation.” REopt Lite Web Tool. Accessed May 4, 2020. https://reopt.nrel.gov/tool/results/d875d523-6969-405b-9258-b428169ca42f.

To cite the REopt Lite model in general, please use:

S. Mishra, J. Pohl, N. Laws, D. Cutler, T. Kwasnik, W. Becker, A. Zolan, K. Anderson, D. Olis, E. Elgqvist, Computational framework for behind-the-meter DER techno-economic modeling and optimization-REopt Lite, Energy Systems (2021).

\subsection{Feedback}

Contact NREL at REopt@nrel.gov to offer suggestions or feedback on the REopt Lite web tool or to explore options for more detailed modeling and project development assistance.

\section{General Description}

REopt Lite is a techno-economic decision support model used to identify potentially costeffective investment opportunities for buildings, campuses, communities, and microgrids. Formulated as a mixed-integer linear program, REopt Lite solves a deterministic optimization problem to determine the optimal selection, sizing, and dispatch strategy of technologies chosen from a candidate pool such that loads are met at every time step at the minimum life cycle cost. The candidate pool of technologies typically includes PV, wind power, CHP, electric and thermal energy storage (TES), absorption chillers, and the existing heating plant, cooling plant, and service connection from the electric utility.

REopt Lite identifies technologies and operational strategies of these technologies that might reduce the cost of energy services at a particular site. Energy services include the site's electricity and thermal energy requirements. These services are conventionally supplied by an electric utility (the grid), a natural gas utility, and off-site fuels transported to the site by pipeline, truck, or rail.

To identify the least-cost set of resources that can provide a site's energy services, the model weighs the avoided utility costs (grid-purchased electricity and purchased fuels) against the cost to procure, operate, and maintain additional on-site DER. If the avoided costs are greater than the ownership costs, the system is life cycle cost effective. REopt Lite identifies which technologies are life cycle cost effective, then sizes each technology and determines their dispatch to maximize their economic value for the set of inputs that describe the case under consideration. 
The load, utility costs, and renewable resources are modeled for every hour of one year. We assume the modeled year represents a typical year and that the load and resources will not change significantly over the user's selected analysis period. Scenarios with load growth or declines over many years cannot be modeled. REopt Lite is a time series model in which energy balances are ensured at each time step and operational constraints are upheld while minimizing the cost of energy services for a given customer. A primary modeling assumption is that decisions made by the model will not impact the markets, i.e., the model is always assumed to be a price-taker. This is in contrast to price maker models in which pricing is a decision variable. REopt Lite also does not model power flow or transient effects.

REopt Lite solves a single-year optimization to determine N-year cash flows, assuming constant production and consumption over all $\mathrm{N}$ years of the desired analysis period. REopt Lite assumes perfect prediction of all future events, including weather and load. All costs and benefits are discounted with the user-specified discount rate to present value using standard economic functions. The user can enter constant rates of change for future costs of grid power, fuels, and operations and maintenance (O\&M) for inclusion into the discounting factors to account for projected cost escalation (or de-escalation) rates. Incentives and taxes are also included in the life cycle cost analysis if the user chooses to include them.

Because the objective function is set to minimize life cycle costs of energy services, sometimes the solution includes no new technologies because the net present value (NPV) would otherwise be negative. In this case, the baseline system is the cost-optimal result. By adjusting some inputs, the user can specify a system type and size rather than having REopt Lite solve for this. In this case, systems are 'forced' into the solution whether it is cost effective or not. In some cases, the model may find that even though the addition of the new asset was forced in by the user, the model may not utilize it because the cost of operating the new asset would be greater than avoiding its use. For example, in a scenario where electricity costs are low, a CHP system, even if it had no initial capital costs, could be more costly to operate due to the cost of the fuel and maintenance than it is to purchase grid electricity and continue to provide heat through the existing heating plant.

\subsection{Technology Models}

REopt Lite models the following technologies: PV, wind power, CHP, battery energy storage, TES, absorption chillers, and backup diesel generators. Because the model weighs the costbenefit tradeoff of these technologies, we also include models of the serving electrical utility rate tariff, as well as a facility's existing heating and cooling systems as required.

All technologies are dispatched on an hourly basis for a typical, or representative, year. There is an implicit assumption that typical meteorological power production profiles for PV and wind are valid over the analysis period, e.g., long-term climate change projections are not included. Furthermore, the user's entered representative loads are assumed not to change significantly over the analysis period.

Figure 1 illustrates the general system configuration of the REopt Lite model, including generation sources, storage devices, and loads. Within the electric load and the heating load, dashed boxes show a subset of those loads that could be dispatched by REopt Lite if certain technologies are selected by the user for consideration. 
The assumed existing infrastructure, namely the electrical grid connection, boiler/heating plant, and electrical chiller plant are shown in bold. The electrical, heating, and cooling distribution systems are also existing infrastructure that the model does not size or cost. The optional userselected components that the model can consider for parallel operation with the existing sources are not bolded.

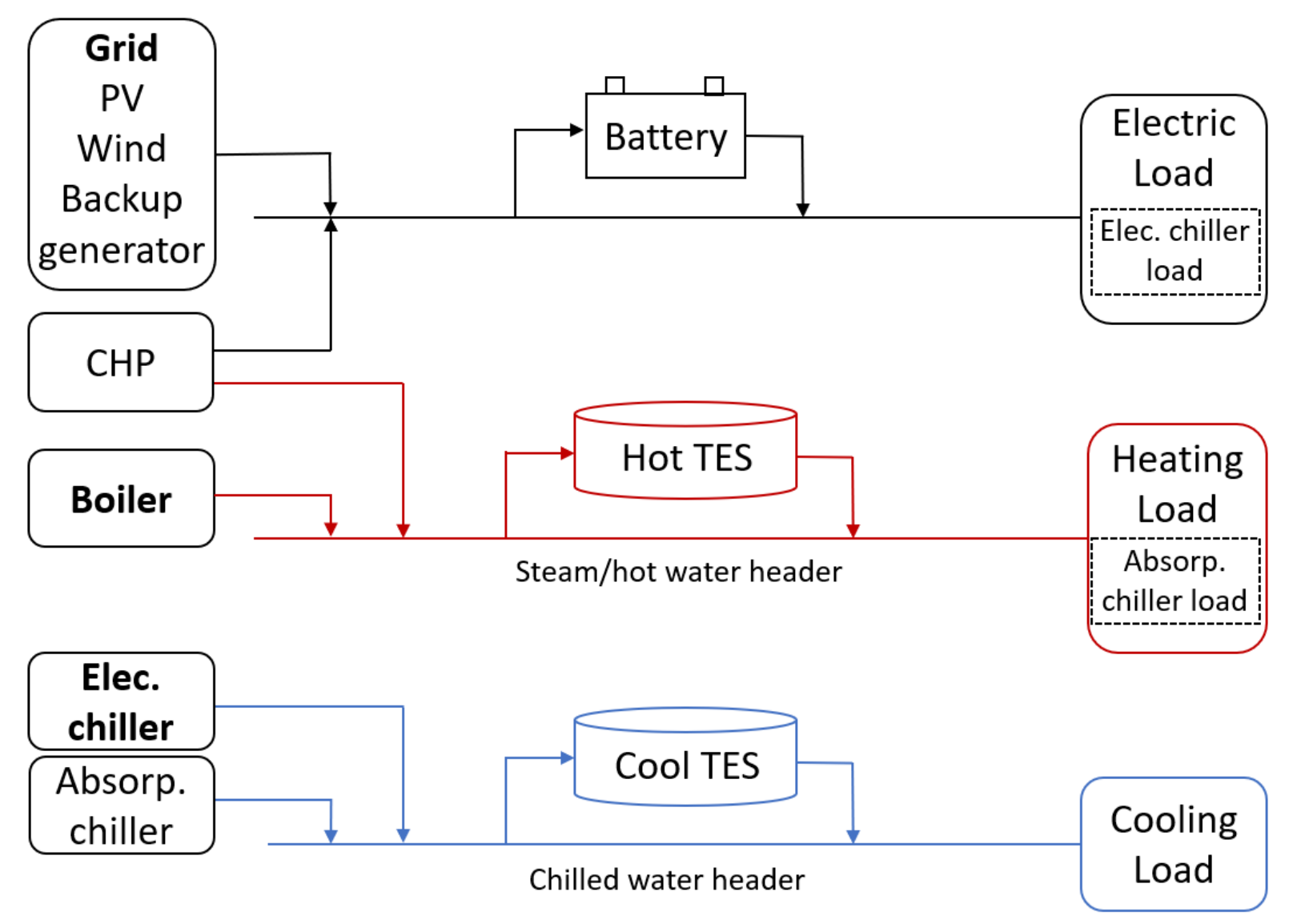

Figure 1. System diagram for REopt Lite power, heating, and cooling technologies and loads

The user can select to screen for all or some subset of the available technologies. If the user does not choose to consider chilled water TES or absorption chiller as an additional potential use of the CHP waste heat, then the cooling load is not a required input and an electrically driven chiller is not explicitly modeled. In this case, the cooling load is assumed to be embedded within the total electrical load and is met by serving all the site's electrical load.

REopt Lite automatically queries NREL databases and modeling tools, including the Utility Rate Database to gather utility rate tariffs, and PVWatts $\AA$, System Advisor Model, and Wind Toolkit to gather renewable energy resource data. PV and wind generation estimates are location-specific time-series profiles. CHP produces both electric and thermal energy. Part-load electric efficiency and heat recovery performance can be modeled as an option. An absorption chiller that produces chilled water from a supply of hot thermal energy may also be considered in conjunction with CHP. The backup diesel generator is available as a power source during grid outages. Utility 
supply is modeled as an infinite source of energy for the site, which can be turned off by the user to explore impact of loss of grid power on DER results and economics.

The electric load is met by the grid, any electricity-producing DER, or discharge from the battery. The modeled facility's heating plant conventionally serves the heating load, and the electric chiller plant conventionally supplies the cooling load. With CHP, absorption chiller, chilled water TES, and hot water TES, the following flows of energy are also considered:

- The grid and optional PV, wind power, and CHP can provide electricity to the electric load, and electricity from these resources can be stored in the battery if a battery is included in the solution.

- The battery, subject to state of charge (SOC), can supply electricity to the electrical load.

- The boiler and CHP can supply hot thermal energy to the heating load, including an optional absorption chiller, and, for hot water systems, hot water can be stored in the hot water TES if hot water TES is included in the solution.

- Hot water TES, subject to level of stored energy, can supply hot water to the heating load, including an absorption chiller if it is included in the solution.

- The electric chiller and the optional absorption chiller can supply chilled water to the cooling load, and chilled water can be stored in the chilled water TES if chilled water TES is included in the solution.

- The chilled water TES, subject to level of stored energy, can supply chilled water to the cooling load.

- The backup diesel generator can serve electrical loads in resiliency analyses when the user selects to include grid outages.

Equipment redundancy requirements and factors of safety are not modeled.

\subsection{Formulation}

REopt Lite solves a mixed-integer linear program. The objective function minimizes total life cycle cost, which consists of a set of possible revenues and expenses over the analysis period, subject to a variety of integer and non-integer constraints to ensure that thermal and electrical loads are met at every time step by some combination of chosen technologies.

The constraints governing how REopt Lite builds and dispatches technologies fall into the following categories:

- Load constraints: Loads must be fully met by some combination of renewable and conventional generation during every time step. Typically, hourly or 15-minute time steps are used in the model.

- Resource constraints: The amount of energy that a technology can produce is limited by the amount of resource available within a region or by the size of fuel storage systems. The energy production of variable technologies is limited by the renewable resource at the location, while the utility grid is assumed to be able to provide unlimited amounts of energy.

- Operating constraints: Dispatchable technologies may have minimum turndown limits that prevent them from operating at partial loads below a specified level. Other operating constraints may limit the number of times a dispatchable technology can cycle on and off each day or impose minimum or maximum SOC requirements on battery technology. 
- Sizing constraints: Most sites have limited land and roof area available for renewable energy installations, which may restrict the sizes of technologies like PV or wind. The client may also specify acceptable minimum and maximum technology sizes as model inputs.

- Policy constraints: Utilities often impose limits on the cumulative amount of renewable generation a site can install and still qualify for a net metering agreement. Other policy constraints may restrict the size of a variable technology system in order for it to be eligible for a production incentive.

- Scenario constraints (optional): Constraints may require a site to achieve some measure of energy resiliency by meeting the critical load for a defined period of time with on-site generation assets.

For more details including the complete mathematical formulation, refer to Appendix B.

\subsection{Temporal Resolution}

REopt Lite uses time series integration to combine the energy production from concurrently operating technologies. The optimization model assumes that production and consumption are constant across all years of analysis, and so only considers the energy balance of Year 1 . The typical time step is one hour, resulting in 8,760 time steps in a typical $\mathrm{N}$-year analysis. This ensures that seasonal variation in load and resource availability is captured. Time steps can be adjusted in the API; in the web tool, they are set to hourly.

\section{Getting Started}

\subsection{Logging In}

Upon accessing REopt Lite (https://reopt.nrel.gov/tool), the user has the option of creating or logging into an existing user account via the Log in/Register link in the upper right corner. REopt Lite can be used without registering or logging in to a user account. However, if a user chooses to set up an account and to log in before running evaluations, their evaluations are saved and can be accessed later.

In order to create a detailed custom electricity rate, build a custom critical load profile, or manage typical and critical load profiles, users must be registered and logged into their account.

There are options to create accounts using Google and/or Facebook. Users can create a Google account that is associated with a non-gmail.com address by clicking on "Use my current email address instead," entering an email address, then following the instructions to verify the ownership of the email address entered. Users signing in with Facebook must be signed into their Facebook account and have platform apps enabled in that account.

\subsubsection{User Dashboard}

Once logged in, the Saved Evaluations button takes the registered user to a dashboard which presents a summary of their stored data from previous evaluations, along with links to view the results page of each evaluation in their browser, copy the evaluation as a basis for creating an edited new evaluation, or to delete the saved evaluation. 


\subsubsection{Custom Load Profiles}

The Load Profiles button gives the registered user the option of viewing Saved Typical Loads or Saved Critical Loads. The Typical Load Profiles page presents a button to upload a new load profile and a summary of all previously uploaded typical load profiles, along with lists of the evaluations that used each load profile, a graph of the load profile, and the option to download the profile. Typical load profiles can be deleted if they are not associated with any evaluations. The user must first delete all associated evaluations in order to enable deletion of a typical load profile.

The Critical Load Profiles page presents a button to upload a new critical load profile and another button to build a new critical load profile. The page also provides a summary of all previously uploaded or built custom critical load profiles, along with lists of the evaluations that used each critical load profile, a graph of the load profile, and the option to download the profile. Critical load profiles can be deleted if they are not associated with any evaluations. The user must first delete all associated evaluations in order to enable deletion of a typical load profile.

\subsubsection{Custom Rates}

The Custom Rates button takes a registered user to a list of previously defined custom electricity rates, or allows them to define a new electricity rate.

\subsection{New Evaluation}

\subsubsection{Step 0: Gathering Data}

The Step 0 section details the advantages of optional registration and logging in to a private account, including the ability to save evaluations, create custom electricity rates, build custom critical load profiles, and manage saved typical and critical load profiles. It also lists the data that should be gathered for different types of evaluation. A Financial evaluation will require site location, electricity rate, and either a custom load profile or the combination of a building type and an annual energy consumption estimate for that building. A Resilience evaluation will require these data plus data defining a planned or potential electric outage. The extra resilience data includes a way of determining the load that will need to be met in an outage: either a percentage critical load factor, a custom critical load profile, or the critical load components that would be required in an outage that can be used to build a critical load profile. The other key data are the expected or desired outage duration to be survived and a starting date and time for the outage. If a generic potential outage is to be modeled, then a worst-case scenario can be used by selecting the outage start time as the peak time of the critical load profile.

\subsubsection{Step 1: Choose Your Focus}

The first step in creating a new evaluation is selecting the focus of the analysis-whether to optimize for financial savings or energy resilience. The default selection is financial savings. If Financial is selected, then Resilience inputs are hidden.

Financial mode optimizes system sizes and dispatch strategy to minimize life cycle cost of energy. Resilience mode does the same thing, but with the added constraint that on-site resources must sustain the critical load, without the utility grid, during the designated outage period. Due to the explicit modeling of the utility grid within REopt Lite, the model can be used to simulate grid 
outages by turning off the grid for certain time steps. The load profile can also be modified during these grid outages to represent a "critical" load (either via a percent scaling factor or by splicing in a critical load). This enables evaluation of all technologies in the model, both during grid-connected mode (vast majority of the year) and during grid outages. This capability is especially important for renewable energy technologies because they are able to generate value during grid-connected mode while also supporting a critical load during a grid outage (whereas backup generators may only be able to operate during an outage due to air quality permits).

\subsubsection{Step 2: Select Technologies}

The second step is selecting the technologies to be included in the analysis-whether to evaluate PV, wind, battery storage, CHP, chilled water storage, or any combination of these technologies. If CHP is selected, you may also select to evaluate hot water storage and/or absorption chiller. If a Resilience evaluation has been chosen, a diesel generator evaluation is also given as an option. Only the inputs for a selected technology are visible. Inputs for any technology that is not selected are hidden.

\subsubsection{Step 3: Enter Data}

The third step is entering site-specific data for the scenario that the user wishes to evaluate. This data includes the location, electricity rate, and consumption details, as well as financial constraints. A variety of inputs are necessary for a REopt Lite analysis, but the tool provides editable default values for most of these parameters. Note that there is an option in the right margin of each section to "Reset to default values." See Section 18 for information on default values.

For a Financial evaluation, there are three required inputs that the user must enter. Two of these entry fields are displayed in the Site and Utility Inputs section when the tool is first opened. These two inputs are site location and the applicable electricity rate for that site location. The third required input is the typical load - entered either as a simulated building type plus an annual energy consumption or as a custom load profile data file upload - entered in the Load Profile section.

For a Resilience evaluation, there are four additional required inputs. The first is the critical energy load profile - entered either as a critical load factor percentage, as a custom critical load profile data file upload, or as a custom-built critical load - in the Load Profile section. The final three required inputs are the outage duration, outage start date and outage start time for the grid outage that the resilience evaluation will model.

There are a total of eleven possible data input sections: Site and Utility, Load Profile, Resilience (visible only when the resilience evaluation is chosen), Financial, Emissions, PV, Battery, Wind, Generator (also visible only when the resilience optimization is chosen), Combined Heat \& Power, and Chilled Water Storage. Inputs for Hot Water Storage and Absorption Chilling are found under Combined Heat \& Power. As each section is expanded, the key driver input parameters for that Data Input section are displayed. In most cases these top inputs in each section will have the greatest impact on the results of the evaluation. Additional parameters in each section can be displayed by selecting the "Advanced Inputs" option. 
Parameters with default values have these prepopulated values displayed in light gray text in the data entry boxes. All these values can be overridden, and those that have been altered by the user will display in a darker text and the default will be displayed in the right margin next to the input box. Each separate section, as well as the entire form, has an option to reset the parameters to default values. See Section 18 for details and explanations of these values.

When all desired inputs have been entered and/or edited, the final step is to select the Get Results button. A new page will display while the tool is optimizing the results. This may take up to several minutes to complete, depending on the complexity of the analysis. The Results page displays recommended system sizes, potential savings, the system dispatch strategy returned from the API, and, if requested, analysis of resilience system economics. The user will have the option of downloading a dispatch spreadsheet, a pro forma spreadsheet, and running an outage simulation. The user can also return to the input page to edit the inputs and alter the scenario for a new evaluation.

Users are cautioned that, although this model provides an estimate of the techno-economic feasibility of solar, wind, CHP, and storage installations, this is not a design tool. The results are indicative of a potential opportunity; they do not describe a design for procurement. Investment decisions should not be made based on these results alone. Before moving ahead with project development, verify the accuracy of important inputs and consider additional factors that are not captured in this model.

\subsection{International Use}

Although REopt Lite is designed for use with locations within the United States, there is a link in the upper right corner, to the left of the Log In/Register link, that provides suggestions for adjustments that can allow the use of most of the tool's features for international locations.

\subsubsection{Site Location \& Utility Rate}

Selecting a site location outside the United States will prompt a message that no electricity rates can be found for the location. This is because the utility rate database used by REopt Lite does not include international locations. However, custom utility rates can be entered as simple annual or monthly rates. Detailed rates, with variable prices dependent on times and months, can also be entered if the user is registered and logged in to a user account. Details of rate structures for some international locations can be found at the International Utility Rate Database.

\subsubsection{Currency}

Currency values are all in U.S. dollars. Conversions from the local currency to U.S. dollars can be made for inputs of utility rates, system costs, and incentive values. Conversion of the final results of the evaluation will then be necessary, from U.S. dollars back to the local currency. One popular tool for currency conversion approximation is the XE Currency Converter.

\subsubsection{Load Profile}

The Load Profile option for simulated load data is based on U.S. building and climate area data. If this simulated load option is used, the simulated load profile should be checked for reasonableness for the climate of the selected location. 


\subsubsection{Financial Information}

Financial, tax and incentive input defaults in all sections need to be carefully considered and altered to match local tax and interest rates and available financial incentives. Default costs for technology systems are also based on typical costs in the United States. Resources for researching international renewable energy costs can be found at the International Renewable Energy Agency.

\subsubsection{Solar Production Data}

Solar production data is taken from the PVWatts dataset, which includes many international locations. REopt Lite will use the closest available location that is found to have resource data, so the user should independently confirm that PVWatts includes data for a location that is acceptably close to their site location. The available resource data locations can be found using NREL's PV Watts.

\subsubsection{PV System Characteristics}

PV System Characteristic defaults need to be altered for locations in the southern hemisphere. The array azimuth for maximum insolation should be changed from $180^{\circ}$ to $0^{\circ}$. The array tilt for fixed ground-mount systems will default to the site's latitude, which will be a negative number that will need to be changed to a positive number in order to avoid an error.

\subsubsection{Wind Resource Data}

Wind systems cannot currently be modeled from the webtool user interface for international locations due to lack of international wind resource data. However, if the user has hourly wind resource data for their site, they can use this data in the API, instead of the webtool interface, to complete an optimization.

\section{Economic Model}

As previously mentioned, the objective of the optimization is to minimize life cycle costs, i.e., to maximize NPV. Other financial metrics like internal rate of return (IRR) and payback are reported but cannot be selected as the driving objective. It is not unusual to get a 'null' solution, where no technologies are recommended, if DERs are not found to be cost-effective. The user can select from two financial models: self-financed owner-operator and third-party financed.

The approach and terminology are based on the Manual for the Economic Evaluation of Energy Efficiency and Renewable Energy Technologies (Short, Packey, and Holt 1995) and abides by the life cycle cost methods and criteria for federal energy projects as described in the Federal Code of Regulations 10 CFR Part 436 - Subpart A, and which are detailed in National Institute of Standards and Technology (NIST) Handbook 135, Life-Cycle Costing Manual for the Federal Energy Management Program (Fuller and Petersen 1995).

\subsection{Definitions, Inputs, and Assumptions}

The primary economic calculations considered are the NPV of the alternative energy project and the total LCC. LCC ${ }^{1}$ is the present value of all costs, after taxes and incentives, associated with

${ }^{1}$ LCC or total life-cycle cost has the meaning as described in (Short, Packey, \& Holt, 1995), where it is abbreviated as TLCC. 
each project option. NPV ${ }^{2}$ is the present value of the savings (or costs if negative) realized by the project. The general equation for NPV is given below:

\section{NPV of alternative $=$ LCC of Business-as-Usual Case - LCC of Investment Case $\quad$ Equation 1}

Here, Business-as-Usual Case refers to the total cost of energy services over the analysis period if the site continues to purchase energy services solely from its existing suppliers. These are typically the site's existing serving utility, but if on-site energy systems exist, those are also included in the Business-as-Usual Case. For example, PV systems or CHP plants already in service at the site are modeled to ensure the Base Case scenario properly represents the site's current utility demand, supply sources, and costs. Life cycle utility costs include annual cost escalation rate projections specific to and specified by the client. For federal clients, utility cost escalation rates are taken from the NIST publication Energy Price Indices and Discount Factors for Life-Cycle Cost Analysis (Rushing, Kneifel, and Lippiatt 2013), as revised each year, or as provided by client.

The Investment Case is the project scenario with additional alternatives to continuing the business-as-usual operation. The Investment Case considers:

- Capital Expenditure $\left(\mathrm{CAPEX}^{3}\right)$ of the alternative project

- O\&M costs of the alternative project

- The cost of fuels

- All applicable incentives made available by utilities, states or the federal government (e.g., Investment Tax Credit (ITC), Production Tax Credit, and accelerated depreciation)

- Balance of remaining utility costs if the alternative project considered does not supply all of the site's energy loads.

Costs that occur in years beyond the base year (Year 0) are discounted to present value. An endof-year discounting convention is applied. The discounting function properly discounts for:

1. One-time future costs (e.g., a PV system's inverter replacement in Year 15 if it is included in the O\&M forecast)

2. Annual recurring costs (e.g., regular annual maintenance for a wind turbine in a real economic analysis)

3. Annual recurring costs that are escalating at a fixed rate each year (e.g., an annual utility cost escalation rate is applied to the base year utility costs to account for projected utility rate increases).

With these considerations in mind, the primary economic inputs into the REopt Lite model are as follows:

- Discount rate: The rate at which the future value of all future costs and savings is discounted - an after-tax value if the owner is a taxable entity

\footnotetext{
${ }^{2}$ NPV as described here has the same meaning as Net Savings (NS) as described in (Fuller \& Petersen, 1995)

${ }^{3}$ Note that the term CAPEX and capital costs are both used interchangeably in this document and have the same meaning.
} 
- Current utility costs and assumed utility cost escalation rates: The expected annual escalation rate for the price of electricity or fuel

- Length of the analysis period: The financial life of the project

- Income tax rate: The percent of income that goes to tax. The tax value default is currently $26 \%$ - the sum of a $21 \%$ federal rate plus a $5 \%$ average state rate

- O\&M cost escalation rate: The expected annual escalation rate for O\&M costs over the financial life of the system

- Tax and non-tax-based incentives depending on the client's tax disposition.

To calculate the economic outputs, REopt Lite makes the following assumptions:

- CAPEX are considered overnight costs (i.e., all projects are completed at the end of Year 0 and produce energy starting in Year 1) and assumed to be the same in both ownership models (see Section 3.2). Construction periods and construction loans are not modeled.

- A site's annual electric and thermal load demand profiles remain constant from year to year for the duration of the analysis period.

- One-year discounting periods are used (i.e., no mid-year discounting subperiods).

- All cash flows occur at end of year.

- When tax benefits are considered, the system buyer has sufficient tax appetite to capture all available tax incentives in their entirety.

- O\&M costs escalate at the O\&M cost escalation rate.

- Sales tax, insurance costs, and property taxes are not considered.

- Debt service coverage and reserve requirements are not considered.

Although the input fields in the user interface are labelled as nominal values, a real or nominal analysis can be performed as long as discount rates, O\&M cost escalation rate (general inflation), and utility cost escalation rates are consistently represented in real or nominal terms. REopt Lite assumes all technologies except battery storage have a useful life equal to the analysis period; any residual value at the end of the analysis period is not captured. For battery storage, one replacement can be modelled during the analysis period.

\subsection{Ownership Models}

Many economic or pro forma financial analyses consider project options only from the perspective of the project owner, assuming that the party that consumes the energy from an energy-producing technology also purchases, owns, and operates the system. However, on-site renewable energy and nonrenewable energy systems are often financed and owned by an unrelated party that does not consume the energy output but instead sells these energy services to the owner of the building or site. In this type of business arrangement, the site acts as the "host" (or off-taker) of the energy project while the third party both finances and owns the project.

A facility owner may consider a project of this type if they do not have or do not want to use their own funds to build energy systems, or if they do not want to take on ownership overhead. In this case, facility owners want to know if a project is economically feasible if a third party builds and operates the system at the facility and sells the energy services to the facility owner. Business arrangements of this type are sometimes referred to as alternative financed projects and include power purchase agreements (PPAs), energy savings performance contracts (ESPCs) or utility energy service contracts (UESCs). 
REopt Lite is formulated to allow techno-economic screenings of projects for facilities under the following general ownership models:

1. Single Party Economic Model: The facility is interested in projects that the facility owner will purchase, own, operate, and consume energy from. This is the conventional ownership model described in the references. The economic screening here answers the question: Should the facility owner consider buying additional energy systems to displace energy purchases from their existing utility and/or other existing assets?

2. Third-Party Economic Model: The facility owner is interested in procuring energy services from a third party that owns and operates the system(s) on or adjacent to the facility owner's property, and sells the energy produced to the facility owner. Here, there are two parties, the Third-Party Owner and the Host, each with potentially different discount rates and income tax rates. The facility owner is the system Host, or consumer of the energy from the project. The Third-Party Owner builds and operates the systems and sells energy services to the Host. The Third-Party Owner is an unrelated party who invests in the project as a business venture. The economic screening here answers the question: Should the facility owner consider engaging an energy services provider to procure electricity, heat, or other energy services to reduce total costs of energy paid to their conventional utility providers or to consume electricity or heat provided by other existing assets?

The Third-Party model of ownership uses the same general economic principles as the Single Party model, but considers two sets of discount rates and tax rates: (1) the Third-Party Owner's discount rate and tax rate for evaluating ownership costs and revenues necessary for the project to be a sound investment for the Third-Party Owner, and (2) the Host's discount rate and tax rate to determine the economic merits of procuring energy services from the Third-Party Owner instead of the serving utility. Alternative financing projects are complex and ultimately need to be evaluated using complex proformas that depend on the financing approach taken. The ThirdParty Model in REopt is a simplified screening-level analysis to identify potential opportunities for facilities considering alternative financing.

The Third-Party Model screens projects that the facility would engage in under an alternative financing plan (e.g., through a PPA or an ESPC). The model considers the perspective of both the Third-Party Owner and the Host. The general approach is as follows:

1. Find the total Net Present Cost of the project using the Third-Party Owner's discount rate, tax rate and all incentives available to the project owner. This discount rate is the same as the Third-Party Owner's IRR. As applied in REopt Lite, the Third-Party Owner's discount rate is Third-Party Owner's IRR after taxes.

2. Determine the annual payment (annuity) for energy services required by the Third-Party Owner over the analysis period to cover all ownership costs at the Third-Party Owner's discount rate (after tax IRR). In the user interface, this is both the Third-Party Owner's 'Annual Payment from Host' and the Host's 'Annual Payment to Third Party Owner'.

3. Determine the LCC of energy for the Host using the Host's discount rate, considering:

- Purchasing energy from the serving utilities and fuel suppliers 
- Energy services payments the Host will make to the Third-Party Owner for procuring energy from the project.

4. Calculate the NPV for the Host, considering payments to conventional utilities in the Business-as-Usual Case and the sum of conventional utility costs and energy services payments in the Alternative Energy Case. If the NPV is greater than zero, the project is considered economically viable for the Host and the Third-Party Owner is able to meet their profit requirements.

\subsection{Economic Incentives}

REopt Lite models three types of incentives for applicable technologies: capital cost-based incentives, production-based incentives, and tax depreciation.

\subsubsection{Capital Cost Based Incentives}

Capital cost-based incentives, or CBI, are structured either as a fraction of the total installed cost or as a rebate amount per DER unit capacity. The user can enter programmatic maximum rebate limits to CBI incentives. The value defaults to 'Unlimited.' Federal and state tax credits are entered as CBI in REopt Lite. The federal percentage-based incentive is treated as a tax-based incentive to model the federal investment tax credit. All other incentives are not tax-based.

Incentives are considered in the following order: utility, state, then federal. For example, if there is a $20 \%$ utility incentive and a $30 \%$ state incentive, the $20 \%$ utility incentive would be applied first, then the $30 \%$ state incentive would be applied to the reduced cost. The incentives are not additive; that is, the site would not get a $20 \%+30 \%=50 \%$ discount.

\subsubsection{Production Based Incentives}

Production-based incentives, or PBI, are entered as a dollar value of the incentive per $\mathrm{kWh}$ produced. The number of years the PBI is available and the maximum incentive amount are available fields. Additionally, the user can enter a maximum available generator size for incentive programs that include a system capacity limit. If there is more than one productionbased incentive offered (for example, a federal and a utility incentive), the combined value can be entered and should be discounted back to year one if the incentive duration differs.

\subsubsection{Modified Accelerated Cost Recovery System}

The Modified Accelerated Cost Recovery System (MACRS) is the current tax depreciation system in the United States. Under this system, the capitalized cost (basis) of tangible property is recovered over a specified life by annual deductions for depreciation. If available, the user may specify the duration over which accelerated depreciation will occur (five or seven years). When claiming the ITC, the MACRS depreciation basis is reduced by half of the value of the ITC.

\section{Existing Facility Infrastructure}

This section provides a detailed description and assumptions used for the performance models of the assumed existing facility infrastructure in REopt Lite. This infrastructure includes electric utility service, centralized heating plant, and, if absorption chiller or cool TES are considered, a centralized cooling plant. REopt Lite does not size and cost this assumed existing infrastructure. 


\subsection{Utility Services}

The site is assumed to be served by an electric utility and, if natural gas is selected by the user, a natural gas utility. In addition, if other fuel types are selected for the heating plant or to be considered for use by the potential CHP system, we assume those fuel storage and delivery components are in place, i.e., they not included in the REopt Lite cost models. The costs for fuels and power via the utility services are user inputs.

\subsection{Heating Plant}

The model construct assumes there is an existing centralized heating plant and heating distribution system that could accommodate the integration of supplementary waste heat from a CHP unit. The heating plant boilers are modeled as a single heat generator; individual boilers in a multiple boiler facility are not modeled. The user selects whether the boiler generates hot water or steam in the user interface using the 'Existing boiler type' dropdown menu. A configuration with both steam and hot water cannot be modeled.

The model does not include boiler turn-down limits (minimum unloading ratio constraint) or minimum runtime constraints, e.g., the model allows the boiler to be off in one hour, run one hour, and then be off the following hour.

Natural gas is the default fuel for the heating plant. Additional fuel options include propane, diesel, and biogas. For natural gas and biogas, the user enters costs in units of \$/MMBtu while the costs for diesel and propane are entered in units of \$/gallon. For the analysis, entered unit costs are converted from $\$ /$ gallon to $\$ / M M B t u$ using the following higher heating values $(\mathrm{HHV})^{4}$ :

- Diesel, 138,490 Btu/gallon (HHV)

- Propane, 91,420 Btu/gallon (HHV).

The user-selected fuel type impacts carbon dioxide (CO2) emissions accounting. See Section 9, Emissions.

Heating plant efficiency is modeled as constant throughout the year, i.e., there are no efficiency adjustments for boiler loading. The default plant efficiency is dependent on whether the user selects hot water or steam for the process heat loop. Efficiency is based on the HHV of the fuel. The default heating plant efficiencies (HHV-basis) are 0.80 for a hot water plant and 0.75 for a steam plant.

For hot water systems, the assumed loop temperatures are:

- Hot water supply temperature of $180^{\circ} \mathrm{F}$

- Hot water return temperature of $160^{\circ} \mathrm{F}$.

In a future release, the user will be able to adjust loop temperatures.

For steam systems, the assumed loop pressure is 150 psig with return to the boiler at a temperature of $180^{\circ} \mathrm{F}$. In a future release, the user will be able to adjust the steam pressure.

${ }^{4}$ https://afdc.energy.gov/fuels/fuel_comparison_chart.pdf 
Fraction of condensate returned is not a required input as described in Section 7.4, Heating Loads. If hot water TES is considered for hot water systems, the distribution loop temperature differential is used to estimate the tank's thermal storage capacity.

It is assumed that the boilers within the heating plant are sized to serve the maximum demand in the facility heating load with an additional $25 \%$ excess capacity. This value is a default assumption that can be changed by the user. This assumption imposes a maximum charging rate of hot water into hot water TES. See Section 16.2, Hot Water Thermal Energy Storage for details.

\subsection{Cooling Plant}

If the user chooses to consider chilled water TES or an absorption chiller, the facility cooling load is assumed to be served by a centralized cooling plant comprised of electrically driven chiller(s). It is also assumed that the cooling plant could accommodate the integration of chilled water TES or a supplemental absorption chiller.

If chilled water TES or absorption chillers are included as candidate technologies, the efficiency of the facility's existing chiller plant needs to be entered by the user or the user can use the default value. In addition, the capacity of the cooling plant is assumed to be fixed to put an upper constraint on the maximum charging capacity of chilled water TES. The default assumption is that the chiller plant cooling capacity is $125 \%$ of the peak cooling load. This is a value that the user can adjust.

Cooling plant unit power requirements are not adjusted based on electric chiller loading or outside air conditions. The user's entered coefficient of performance (COP) value is assumed to represent the average cooling plant performance throughout the year. The COP includes the power requirements for the chiller(s) as well as the pumps and cooling tower fans on the chiller's condenser heat rejection system.

The user can use the default COP value if their annual average COP is unknown. The default value depends on the assumed capacity of the chiller(s). These are determined by the cooling loads entered by the user and the following assumptions:

- Chillers are water cooled.

- By default, the cooling plant's capacity is assumed to be 1.25 times the peak cooling load in the interval data. This value can be modified by the user.

- For peak cooling loads less than or equal to 300 tons, the cooling plant is assumed to have one chiller. For peak cooling loads greater than 300 tons, we assume there are two or more chillers of approximately equal capacity, with no chiller capacity exceeding 800 tons (Pacific Northwest National Laboratory 2016).

The default COP in the bottom row of Table 1 are used as provided (Sweetser 2020). 
Table 1. Default COPs for Existing Cooling Plant

\begin{tabular}{|l|c|c|}
\hline & Chiller capacity <= 100 tons & Chiller capacity > 100 tons \\
\hline Chiller power (kW/ton) & 0.60 & 0.55 \\
\hline $\begin{array}{l}\text { Condenser heat rejection } \\
\text { (kW/ton) }\end{array}$ & 0.20 & 0.20 \\
\hline $\begin{array}{l}\text { Chiller plant total power } \\
\text { (kW/ton) }\end{array}$ & 0.80 & 0.75 \\
\hline $\begin{array}{l}\text { Default chiller plant COP } \\
\text { (kW thermal/kW electric) }\end{array}$ & $\mathbf{4 . 4 0}$ & $\mathbf{4 . 6 9}$ \\
\hline
\end{tabular}

In any hour, the cooling load must be met by some combination of the existing electrical chiller(s), absorption chiller, and chilled water TES if they are included.

The model does not include turn-down limits (minimum unloading ratio constraint) on the chiller plant.

If chilled water TES is considered, the distribution loop temperature differential is used to estimate the tank's thermal storage capacity. See Section 16.1, Chilled Water Thermal Energy Storage for details.

The assumed chilled water loop temperatures are (Pacific Northwest National Laboratory 2016):

- Supply temperature: $44^{\circ} \mathrm{F}$

- Return temperature: $56^{\circ} \mathrm{F}$.

In a future release, the user will be able to adjust chilled loop temperatures which will only impact the thermal storage capacity of chilled water TES per unit gallon of storage.

\subsection{Land and Roof Area Available}

Users can specify the amount of land and/or roof area available for DER. Land area available is used to limit the amount of PV or wind recommended at the site; roof area available is used to limit the amount of PV recommended. These inputs do not limit the size of any other technology.

PV size is constrained by land area available, assuming a power density of six acres per MW, and by roof area available, assuming a power density of $10 \mathrm{DC}-\mathrm{Watts} / \mathrm{ft}^{2}$. Wind size is constrained by land area available, assuming a power density of 30 acres per MW for turbine sizes above 1.5 MW. The default value is unlimited, meaning PV or wind size is not limited by land or roof area available. Note that both land and roof availability limits should be entered to limit PV size.

\section{Electricity and Fuel Tariffs}

This section describes the utility rate tariff inputs to REopt Lite.

\subsection{Electric Rate Tariff}

For all evaluations, details of the site's electrical rate tariff must be specified. The electricity rate can be selected from a list of rates available within 25 miles of the user-entered location. The 
rates are downloaded from the Utility Rate Database (URDB)..$^{5}$ If available, the most common rates are listed at the top of the list. Utility rates that are not in URDB can be modeled as custom rates.

A custom electricity rate can be modeled as an annual, monthly, or detailed rate. If the electricity rate will stay constant through the year, select the "Annual" option and enter the $\$ / \mathrm{kWh}$ Energy cost and, if relevant, the $\$ / \mathrm{kW}$ Demand cost. If an "annual" demand charge is specified, it will still be applied on a monthly basis. If the electricity rate varies by month during the year, select the "Monthly" option and enter the $\$ / \mathrm{kWh}$ Energy cost and, if relevant, the $\$ / \mathrm{kW}$ Demand cost that applies in each month of the year.

If the electricity rate varies during a single month, such as a rate with weekday/weekend or timeof-use rate differences, select the Detailed option. You must be registered and logged in to a user account to access this feature. The Custom Electricity Rate Builder will open and allow you to enter different rates for different time periods, along with time and month schedules for applying these period rates. Once you have named, created, and saved detailed custom rates, they will show up in the "Select Custom Rate" dropdown menu on the main input page and they can be selected to be applied to a current optimization. To build a custom rate tariff:

- Start by entering a name for the custom rate. Once you have named, created, and saved detailed custom rates, these names will show up in the "Select Custom Rate" dropdown menu on the main input page and can be selected to be applied to an optimization. An optional description can also be entered in order to assist in identifying a custom rate.

- Enter each separate rate into the Rate Periods tables for both Energy Charges and Demand Charges. If the rate for a time period includes usage tiers, add tier(s) to that period and enter the maximum energy purchases allowed in the tier(s). The final tier will have unlimited maximum usage.

- After you have defined the Rate Periods, use the Weekday and Weekend Schedule Tables to select the months/times when each period applies. When you have selected a block of time cells, a popover will appear with a dropdown menu so that you can select the relevant period for those cells.

- Periods do not have to be sequential; however, tiers within a given period must be sequential.

The Custom Electricity Rate Builder allows for modeling utility rates that do not appear in the URDB. Currently, this option can only be chosen as a substitute for the URDB rates and not as an additional add-on charge to a URDB rate.

The Custom Electricity Rate Manager allows you to view, edit, and copy the detailed custom electricity rates that you have created. NOTE: Once a custom rate has been used in an optimization, that particular rate can no longer be edited or deleted. However, the rate can be copied to create a new or corrected rate. The table lists your custom rates in chronological order based on when they were created. The name and description you assigned are listed in the table along with the maximum and minimum charges. If you wish to look at the details of the rates by time period, click on View Charge Periods.

\footnotetext{
${ }^{5}$ https://openei.org/wiki/Utility_Rate_Database
} 


\subsubsection{CHP Standby Charge}

Standby tariffs for on-site generation are sometimes imposed to cover the utility's cost to provide backup power to the customer for periods of time when the customer's generator might be unavailable due to planned or unplanned maintenance activities. Standby tariffs are not unusual for CHP systems. Sometimes described as 'partial requirements' tariffs, they can take the form of a relatively simple additional charge added to a customer's existing tariff, sometimes described as a 'full requirements' tariff, or can involve switching to an entirely different tariff if CHP is installed. Tariff switching, i.e., modeling both the existing tariff and alternative tariffs that may be activated if the consumer were to install certain types of DG, cannot be modeled in REopt Lite. ${ }^{6}$ However, the user can include potential standby charges that might be imposed if CHP is installed that are added to the existing electricity tariff by using the 'CHP standby charge based on CHP size $(\$ / \mathrm{kW} / \mathrm{month})$ ' field in the rate tariff section of the user interface. This option is only available and visible to the user when CHP technology is included.

This optional additional standby charge for CHP includes monthly charges based on the installed power capacity of CHP $(\$ / \mathrm{kW} /$ month of CHP rated capacity). This is a fixed monthly charge dependent on the CHP rated power output. Standby demand charges are entered as a single value and applied monthly ( $\$ / \mathrm{kW}$-month). The default value is $\$ 0$.

\subsubsection{Exporting to the Grid}

By default, REopt Lite assumes that electricity generated by all DERs except CHP can be exported to the grid. While the value of exported power can be set to zero (by entering a net metering limit and wholesale rate of zero), power can still be exported. It is not uncommon for power export to be prohibited as part of a CHP interconnection agreement with the serving electric utility. In REopt Lite, this prohibition is the default constraint. The user can remove this constraint by using the 'CHP allowed to export to the grid' check box. Even if there is no compensation from the utility for exported power, allowing export could change the results of the solution because it would allow the CHP system to serve site loads (or net loads if other DER are included) that at times may be below the minimum turndown limit of the CHP prime mover. See Section 14, Combined Heat and Power for more information on CHP minimum turndown limits.

\subsubsection{Net Metering}

Net metering policies provide credits to utility customers for approved customer generation that exports energy to the grid. The net metering limit determines the maximum size of total combined systems that can be installed under a net metering agreement with the utility. Projects sized up to the net metering limit will receive credit for any exported energy at the electric retail

\footnotetext{
${ }^{6}$ If the standby 'supplemental' tariff cannot be modeled as the standard 'full requirements' tariff plus some combination of the charges described above, the user will have to model the standby tariff in the tariff template instead of the full requirements tariff. The user will have to keep in mind that the financial results are only relevant if CHP is included in the investment scenario returned and that the business-as-usual costs in that solution are not accurate because they are calculated for the standby tariff rather than the non-standby tariff. Further, if the investment scenario also includes PV, wind power, and/or battery, the user should confirm with the serving utility whether the modeled standby tariff applies to the hybrid CHP system.
} 
rate at the time of export. Projects sized greater than the net metering limit will receive credit at the wholesale rate for any energy exported.

Information on state net metering limits is available at www.dsireusa.org. The user is not required to enter a value for this input. By default, REopt Lite assumes that net metering is not available (net metering limit $=0$ ).

Currently, only PV and wind are eligible for net metering in REopt Lite. In a future release, the user will be able to select CHP as an eligible technology.

\subsubsection{Wholesale Rate}

The wholesale rate for exported energy applies to projects that are not net metered or projects sized greater than the net metering limit. If a wholesale rate is entered and net metering is not available (i.e., net metering size limit is $0 \mathrm{~kW}$ ) or if the project is sized greater than the net metering limit, then the project will receive credit for any exported energy at this wholesale rate, up to the annual site load so that the site does not become a net exporter of electricity.

\subsection{Fuel Costs}

Fuel costs are entered for analyses that include CHP. For CHP analyses, the fuel type and fuel costs must be entered for both the existing centralized heating plant and for the CHP technology to be screened. Fuel types are used to track $\mathrm{CO} 2$ emissions associated with their consumption. No other defaults, including CHP prime mover performance and costs, are adjusted when the user changes the fuel type from the natural gas default.

Fuel costs can be entered as a single annual value or as a monthly value. This is the cost of fuel for the existing boiler to supply the heating load. The units are \$/MMBtu based on the HHV of the fuel.

\section{Loads}

This section describes the required load inputs. Because REopt Lite models a full year, the model requires typical load values for every hour of the year. If finer interval data is available, e.g., 15minute interval data, the user can input that data and REopt Lite user interface will down-sample it to 1-hour intervals. If running the API directly, the user can run at 15-minute, 30-minute, or 1hour interval length. Because only one year of load is modeled, the implicit assumption is that the load does not change significantly from year to year over the analysis period.

For PV, wind, and battery storage analysis, only electricity loads are needed. For CHP analysis, heating loads are also required. If the user considers chilled water TES or absorption chillers, cooling load interval data is also required.

\subsection{Actual (Custom) Load Profile}

If available to the user, the user uploads actual interval load data for the facility. In the REopt Lite user interface, this is called a custom load profile. Actual load data will result in the most accurate results. If "Upload" is selected, the user must upload one year (January through December) of hourly, 30-minute, or 15-minute load data, in $\mathrm{kW}$, by clicking the browse button 
and selecting a file. A sample custom load profile ${ }^{7}$ is available, which includes an optional header and optional additional column A with the 8,760 hour-long intervals listed for reference.

The file should be formatted as a column of $8,760,17,520$, or 35,040 rows. The file should be saved as a .csv file. If the file does not contain the correct number of rows $(8,760,17,520$, or $35,040)$, or there are rows with blank entries, the user will receive an error message. If the available load data is for a leap year, please delete the data for December 31 to shorten the file length to $8,760,17,520$, or 35,040 rows.

In the web interface, the option to use 15-minute or 30-minute load data is provided for user convenience, not for higher model resolution. If 15-minute or 30-minute data is uploaded, it will be down-sampled to hourly data for the evaluation. In the API, the user can run sub-hourly analysis.

If the load profile is from a leap year, where an extra day's worth of data is part of the file, the December 31 data should be deleted so that the file will be the correct length. Deleting December 31 will have the least impact on the evaluation results. The February 29 data should not be deleted, because it would impact the day of the week status for all days from March to December, and many utility rates have different rates for weekdays and weekends. The calendar year the load profile represents is entered in the 'Year of load profile' field. This information is needed to correctly apply tariffs that vary by days of the week. The default for this input is the current year.

\subsection{Simulated Load Profile from Models}

If actual interval data is unavailable, the user has access to 16 load profiles from DOE Commercial Reference Building (CRB) models that can be used either to analyze one of the standard building types or to synthesize user-entered annual or monthly total values into hourly load profiles (see Table 2). The climate for CRB loads is selected based on the user's entered location (see Table 3). In addition to using these load profiles, the user can model flat or constant loads. In the user interface, loads generated with CRB models and flat load options are called Simulated Load Profiles.

The loads are generated from DOE's post-1980 CRB models for the climate zone of the site using EnergyPlus ${ }^{\circledR}$ simulation software. The simulated load profile is created for a generic year that starts on Sunday. Because January 1, 2017 is a Sunday, 2017 shows as the load year when using CRB loads. If the user uses Simulated Load Profiles and overwrites the default Annual Energy Consumption displayed in the interface for the selected building type model, the Simulated Load Profile will be scaled to match the user's Annual Energy Consumption value. This is useful when the user has total annual energy consumption but requires use of the CRB hourly interval load values to synthesize interval data. The user can select to enter energy totals by month and the CRB hourly interval data will instead be scaled to match the monthly totals entered. The building chosen for the electric load simulation does not need to be the same building type chosen for the heating or cooling loads.

\footnotetext{
${ }^{7}$ https://reopt.nrel.gov/tool/load_profile template.csv
} 
Table 2. DOE Commercial Reference Building Types

\begin{tabular}{|l|c|c|}
\hline Building Type & Floor Area (ft ${ }^{\mathbf{2}}$ ) & No. of Floors \\
\hline Large Office & 498,588 & 12 \\
\hline Medium Office & 53,628 & 3 \\
\hline Small Office & 5,500 & 1 \\
\hline Warehouse & 52,045 & 1 \\
\hline Stand-alone Retail & 24,962 & 1 \\
\hline Strip Mall & 22,500 & 1 \\
\hline Primary School & 73,960 & 1 \\
\hline Secondary School & 210,887 & 2 \\
\hline Supermarket & 45,000 & 1 \\
\hline Quick Service Restaurant & 2,500 & 1 \\
\hline Full-Service Restaurant & 5,500 & 1 \\
\hline Hospital & 241,351 & 5 \\
\hline Outpatient Health Care & 40,946 & 3 \\
\hline Small Hotel & 43,200 & 4 \\
\hline Large Hotel & 122,120 & 6 \\
\hline Midrise Apartment & 33,740 & 4 \\
\hline
\end{tabular}

Source: https://energy.gov/eere/buildings/commercial-reference-buildings

Table 3. Climate Zones

\begin{tabular}{|l|c|}
\hline Climate Zone & Representative City \\
\hline 1A & Miami, Florida \\
\hline 2A & Houston, Texas \\
\hline 2B & Phoenix, Arizona \\
\hline 3A & Atlanta, Georgia \\
\hline 3B-Coast & Los Angeles, California \\
\hline 3B & Las Vegas, Nevada \\
\hline 3C & San Francisco, California \\
\hline 4A & Baltimore, Maryland \\
\hline 4B & Albuquerque, New Mexico \\
\hline 4C & Seattle, Washington \\
\hline 5A & Chicago, Illinois \\
\hline 5B & Boulder, Colorado \\
\hline $6 \mathrm{~A}$ & Minneapolis, Minnesota \\
\hline $6 \mathrm{~B}$ & Helena, Montana \\
\hline 7 & Duluth, Minnesota \\
\hline 8 & Fairbanks, Alaska \\
\hline
\end{tabular}


Dropdown menu options include the 16 modeled building types and flat load options - for a site with a relatively constant electric load. Flat loads are meant to approximate the hourly load(s) using average energy consumption values. These flat loads are based on different operating schedules (hours per day / days per week) listed below. The values for annual or monthly energy are spread out evenly throughout the days/hours included in the description of each load below:

- 24/7 - constant load for all days/hours of the year (truly "flat")

- $24 / 5$ - all hours of the weekdays

- 16/7 - two 8-hour shifts for all days of the year; 6-10 a.m.

- $16 / 5$ - two 8-hour shifts for the weekdays; 6-10 a.m.

- $8 / 7$ - one 8-hour shift for all days of the year; 9 a.m. -5 p.m.

- $8 / 5$ - one 8 -hour shift for the weekdays; 9 a.m.-5 p.m.

The annual or monthly energy values for these flat loads are expected to be entered by the user; however, the model provides default annual energy load values which is the average of all the CRB types for a given climate zone.

\subsubsection{Modeling a Campus with Multiple Simulated Building Load Profiles}

The user can choose multiple commercial reference building types to model a space with mixeduse or multiple buildings on a campus. If "Simulate Campus" is selected, an annual electric consumption for the entire campus is entered along with up to five building types and the percentage of that annual total energy consumption that each of the building types is expected to consume. The simulated load for each building type will be scaled based on the percentage of the annual energy consumption entered. REopt Lite will use the resulting blended simulated electric load profile in determining a single optimally sized energy system for the entire campus.

\subsection{Electric Loads}

The electric interval data entered or generated with CRB models is the facility's total electric consumption through the utility meter that DER could offset. There is no cost function for integrating multiple metering points within a facility and therefore it is assumed the loads entered are for a single electric meter and are addressable by DER. The units for electric interval load are $\mathrm{kW}$. The units for Annual Energy Consumption and Monthly Energy Consumption are kWh.

\subsection{Heating Loads}

The heating load can include space heating, domestic hot water, industrial heating, and any hightemperature thermal energy provided to the absorption chiller if all these loads can be served through a single tie in from the CHP heat recovery system.

The entered heating load interval data has units of fuel (MMBtu of fuel/hour, HHV-basis). Units of fuel, rather than heat, are used since it is assumed that the user is likely to have total fuel consumption from utility bills or invoices and will use CRB modeled heating loads to synthesize hourly interval data that matches the user-entered total fuel consumption. Fuel loads are converted to thermal values (heat) using the heating plant thermal conversion efficiency. The resultant heating loads are gross loads on the boiler(s); therefore, heat for deaerator makeup water and heating losses in the distribution piping are included. 
We assume the heating load entered can be served by (is addressable by) the CHP system. If some of the total heating load is not addressable (for example, it is used for cooking or other processes that are not served by the heating loop), the user should reduce the heating load entered to only the addressable portion.

\subsection{Cooling Loads}

The electrical consumption of the cooling plant is assumed to be included within the total facility electric loads. However, if the user is interested in modeling chilled water TES or absorption chillers, the user needs to specify the amount of cooling thermal energy delivered by the cooling plant. To model, the cooling load is required for every hour of the year.

If available, the existing hourly cooling plant thermal load (units of tons of cooling) is entered by the user. The associated electricity consumption is calculated using user-entered or default cooling plant COP value. If the cooling thermal load is not known, the user may also enter the cooling load as a fixed fraction of the total electric load, either on an annual or monthly basis. This load fraction is multiplied by the total electric load to calculate cooling electric consumption, and then it is converted to units of thermal cooling demand using the cooling plant COP.

If cooling load interval data is unavailable to the user, the user can still screen for chilled water TES and absorption chillers by estimating the cooling loads using the CRB model loads as described in Section 7.2. The user may update the annual or monthly cooling load (units of tonhour) to scale the hourly CRB cooling load profile.

We assume cooling losses in the distribution piping are captured in the entered cooling load; losses in distribution are not separately modeled.

\section{Resilience Analysis}

By default, the REopt Lite web tool optimizes systems to maximize grid-connected economics. Users have the option of specifying additional resilience requirements to design a system that will also sustain a critical load for a specified outage period. Currently, REopt Lite can only model one outage period per year.

\subsection{Critical Load}

The critical load is the load that must be met during a grid outage. It can be calculated as a consistent percent of the typical load profile that is being used, uploaded as a separate custom load profile, or built specifically to correspond to important loads at the site.

If "Percent" is selected, the critical load is a percentage of the typical load profile. This factor is multiplied by the typical load to determine the critical load that must be met during the specified outage period. If "Upload" is selected, the user can upload one year of hourly, 30-minute, or 15minute critical load data. If "Build" is selected, the user can create a custom critical load profile based on specified load components. Only the one active option for specifying the critical load will be applied to the optimization. 


\subsubsection{Critical Load Builder}

The Critical Load Builder allows you to create a daily emergency load profile by building a list of equipment that is critical at your site - along with wattage, quantity, daily operation hours, and annual operation months. Once you have named, built, and saved critical load profiles, they will be available for selection from the Critical Load Profile dropdown menu on the main input page, and can be used in an optimization. You must be registered and logged in to a user account to access this feature. This tool is based on SolarResilient, a tool developed by Arup, under contract to the City and County of San Francisco, with funding from DOE.

To build a new critical load profile, the registered and logged-in user can click the "Build New Critical Load Profile" link and build a new load in the resulting pop-up window while retaining the other inputs already entered. Alternatively, the user can click "Build, copy, and manage your critical load profiles" below the blue box, or "Critical Loads" in the top right-hand corner of the webpage and be taken to a different page to either copy and edit a previously built critical load or to build a new critical load profile from component electrical loads. If the user chooses either of these options, a new evaluation must be started and all inputs that had been entered for the current optimization will need to be re-entered.

To build a critical load profile:

- Start by entering a name for the Critical Load Profile. Once you have named, built, and saved critical load profiles, they will be available for selection from the Critical Load Profile dropdown menu on the main input page, and can be used in an optimization.

- Select load components from the dropdown list. The load component will populate with default suggestions for the power, hours, and months.

- Once added, you can edit the details of the load component to better simulate your critical load conditions.

- Add as many load components as necessary. The last load in the dropdown menu is a custom load, which can be used as a starting point to add components that are not in the menu.

Note that these components are being modeled as flat loads at user-specified power and operation times. There is no cycling, for example, on the air conditioner or space heater. The load does not change based on the weather or room temperature.

\section{Load Type}

Select a preexisting load type and add the load component to your new critical load profile. Once added, you can edit the details of the load component to best simulate your critical load conditions. Add as many load components as necessary.

\section{Power (W)}

This is the power requirement for the selected load type. Default values are taken from Lawrence Berkeley National Laboratory's Home Energy Saver Engineering Documentation, ${ }^{8}$ ENERGY STAR Certified Product data sets, ${ }^{9}$ and the DOE Appliance and Equipment Compliance

\footnotetext{
${ }^{8}$ http://hes-documentation.lbl.gov/calculation-methodology/calculation-of-energy-consumption/majorappliances/miscellaneous-equipment-energy-consumption/default-energy-consumption-of-mels

${ }^{9}$ https://www.energystar.gov/productfinder/advanced
} 
Certification Database. ${ }^{10}$ Many appliances have the wattage stamped on the unit, representing the maximum power drawn by the appliance. The wattage can also be estimated by multiplying the electric current draw, in amperes, by the voltage used by the appliance (typically 120 volts). Amperes may be stamped on the unit or listed in the owner's manual. Energy.gov also provides a calculator for estimating appliance and electronic energy use. ${ }^{11}$

\section{Start Hour}

Start hour is represented similar to military time. For example, 0 represents 12 a.m. and 16 represents 4 p.m. To simulate a component that would run all day, the start hour would be 0 and the end hour would be 24 . To simulate a component that runs from 3 a.m. to 5 p.m., the start hour would be 3 and the end hour would be 17. The start hour must be a whole number and cannot be greater than 23 (representing 11 p.m.).

\section{End Hour}

End hour is represented similar to military time. For example, 1 represents 1 a.m., 13 represents 1 p.m., and 24 represents 12 a.m. on the following day. To simulate a component that would run all day, the start hour would be 0 and the end hour would be 24 . To simulate a component that runs from 3 a.m. to 5 p.m., the start hour would be 3 and the end hour would be 17. The end hour must be a whole number and cannot be less than 1 (representing 1 a.m.).

\section{End Month}

To specify a load component duration of one month, select the same start month and end month. The year of the custom critical load profile is assumed to be the same as the year set for the custom load profile.

The Critical Load Profiles summary allows you to view, edit, and copy the critical load profiles that you have built. The table lists your critical load profiles in the chronological order in which they were created. The name and description you assigned are listed in the table along with the minimum, average, and maximum loads. The dates for the minimum and maximum load values refer to the first chronological instance of that minimum or maximum load. If you wish to look at the details of the critical load profiles by time period, click on the icon to view load profile components. Icons are also available to chart or download the critical load profile. Once a critical load profile has been used in an optimization, that particular load profile can no longer be edited or deleted. However, the load profile can be copied to create a new or corrected load profile.

\subsection{Outage Start Time and Duration}

The user specifies the outage period that the system must sustain by specifying the outage start date, time, and duration (number of hours). The system will be sized to minimize the life cycle cost of energy, with the additional requirement that it must also sustain the critical load during the outage period specified. The outage duration must be a number between zero and 8,759.

In general, selecting an outage start date when the site's load is higher (often summer) will result in larger system sizes that can sustain the critical load during more outages. Selecting an outage

\footnotetext{
${ }^{10} \mathrm{https}$ ://www.regulations.doe.gov/certification-data/products.html $\# \mathrm{q}=$ Product Group s\%3 3 *

${ }^{11} \mathrm{https} / / / \mathrm{www}$.energy.gov/energysaver/save-electricity-and-fuel/appliances-and-electronics/estimating-applianceand-home
} 
period during a time of year when the site's load is lower will result in smaller system sizes that sustain the critical load during fewer outages. However, solar and/or wind resource will also impact the resiliency of the system. The user can choose to automatically populate the outage start date and time with the date and time of the maximum load hour using the "autoselect using critical load profile" link.

Finally, the user selects whether the outage is a major outage, occurring once per project lifetime, or a typical outage, occurring annually. If Major Outage is selected, the avoided outage costs are calculated for a single outage occurring in the first year of the analysis. This is the default selection. If Typical Outage is selected, the outage event is assumed to occur every year of the analysis period. In this case, the avoided outage costs for one year are escalated and discounted to account for an annually recurring outage. The selection made in this input will not impact the optimization results or NPV calculation for the project. It will affect only the results presented in the Effect of Resilience Costs and Benefits section where avoided outage costs and NPV after microgrid costs and benefits are presented.

For information on typical outages in the United States, the user can check Electric Power Monthly, the U.S. Energy Information Administration's compilation of the location, duration, and description of major electric disturbances by month.

\section{Emissions}

REopt Lite estimates CO2 emissions for both the Business-as-Usual Case and the optimal (Investment) case using default values for the United States or user-entered values. Pollutant emission accounting beyond $\mathrm{CO} 2$ (e.g., NOx, SOx, CO, VOCs, particulates) for U.S. locations, grid emission factors, and transmission and distribution (T\&D) losses are auto-populated based on the site location. These data come from the U.S. Environmental Protection Agency (EPA). A dropdown is provided to allow the user to select U.S. national grid subregions that differ from the user-entered address or to enter their own emissions factors. T\&D losses are included in the default emissions factors so the user will have to account for those in any user-entered values.

Emission factors for on-site fuel consumption default to the appropriate values for the selected fuel types.

Emission factors are entered for:

- Grid electricity in units of $\mathrm{lbs} / \mathrm{kWh}$

- Fuels in units of lbs/MMBtu.

$\mathrm{CO} 2$ emissions total outputs are reported in units of U.S. tons.

The CO2 emissions analysis follows the general methodology and guidance described in EPA's Fuel and Carbon Dioxide Emissions Savings Calculation Methodology for Combined Heat and Power Systems (EPA 2015). However, instead of using the EPA's eGRID annual average emission factors, as described in this reference, hourly emission factors from EPA's AVERT tool 
are employed for regions where AVERT provides hourly emissions estimates. ${ }^{12}$ AVERT has emission factors for the continental United States but does not have hourly emission factors for Hawaii and Alaska. For analyses in Hawaii and Alaska, eGRID annual average emission factors are used. For regions outside of the United States, the user enters grid emission factor(s), if available. If emission factors are not provided for grid-purchased electricity outside of the United States, grid emissions will not be calculated.

Using AVERT hourly emission factors, where available, for grid-purchased electricity more accurately estimates the impact of CHP, PV, wind power, battery systems, and each site's timedependent load profile than using a single annual average value due to the time dependence of grid emissions.

We calculate $\mathrm{CO} 2$ emissions of the Business-as-Usual Case (before investment scenario) and Investment Case, which could include a combination of technologies, including PV, wind power, battery, CHP, and CHP-enabling technologies of TES and absorption chillers. The difference between the $\mathrm{CO} 2$ emissions of the Business-as-Usual Case and the Investment Case is the net $\mathrm{CO} 2$ avoided (or gained). Estimated avoided $\mathrm{CO} 2$ emissions are calculated as the total difference between the facility's pre- and post-project energy source inputs of utility-purchased electricity and fuels.

Emissions accounting is for $\mathrm{CO} 2$ only. For utility grid-purchased electricity, factors for $\mathrm{CO} 2$ 'equivalent' (CO2e) contribution from other pollutants, namely N2O (nitrous oxide) and CH4 (methane), can be found in some references. However, estimating these non-CO2 emissions from the various possible CHP prime movers is difficult because they depend on the type, make and model, and load on the prime mover, as well as the level of emissions controls installed with the CHP system (ASHRAE 2015). By review of EPA's eGRID tables, the difference in grid-sourced electricity emissions factors for $\mathrm{CO} 2$ and $\mathrm{CO} 2 \mathrm{e}$ is $1 \%$ for Northeast Power Coordination Council (NPCC) New England and less than 1\% for all other regions. Because CO2 equivalence of non$\mathrm{CO} 2$ pollutants is relatively small for grid-sourced power (per eGRID tables), and because their estimation for CHP is highly uncertain and relatively small, they are not included.

\subsection{CO2 Accounting}

We account for $\mathrm{CO} 2$ emissions, $C$, using the equation:

$$
C_{\text {site }}=C_{\text {utility-electricity }}+C_{\text {fuels }}[\mathrm{lbs} \text { CO2] Equation } 2
$$

$C_{\text {site }}$ is the mass of $\mathrm{CO} 2$ emissions in pounds.

$C_{u t i l i t y-e l e c t r i c i t y}$ is $\mathrm{CO} 2$ emissions for utility-purchased electricity consumed at the site. It includes the emissions associated with the utility's sources of generation as well as transmission and distribution system losses. It is calculated in the following equation as:

$$
C_{\text {utility-electricity }}=E F_{g} * k W h_{u t i l i t y} *\left(1+L_{T D}\right) \quad \text { Equation } 3
$$

\footnotetext{
${ }^{12}$ A 1 MW load is entered into the AVERT spreadsheet for every hour of the year on the 'Enter EERE data' tab (1 is entered in "Reduce each hour by constant MW", cell G17).
} 
$E F_{g}$ is the $\mathrm{CO} 2$ emissions factor for the serving utility (grid) in units of $1 \mathrm{bs} \mathrm{CO} 2 / \mathrm{kWh} . E F_{g}$ varies by hour when sourced from AVERT. The term $k W h_{\text {utility }}$ is the electricity sourced from the utility.

The term $L_{T D}$ is the estimated T\&D losses from the generator to the facility being screened (1 $\mathrm{kWh}$ of electricity measured at the site's utility meter actually requires that more than $1 \mathrm{kWh}$ of electricity generated at the power plant due to the line losses to transport electricity to the consumer). Note that AVERT hourly emission profile outputs include T\&D losses in the emission factors. EPA's eGRID emission factor tables do not include T\&D losses within the reported emission factor; they are provided separately. However, they have been embedded into the emission factors for these locations in REopt Lite so REopt Lite grid emission factors from both AVERT and eGRID include T\&D losses. If a user enters user-provided emission factors, the T\&D losses should be included in the entered values.

$C_{f u e l s}$ is the $\mathrm{CO} 2$ emissions associated with consumption of fuels on-site. It includes fuels used for process heat loads and consumed in on-site generators like CHP.

$$
C_{\text {fuels }}=\text { Fuel consumed } * E F_{f} \quad \text { Equation } 4
$$

The term $E F_{f}$ is the emission factor for fuels consumed on site.

\subsection{Grid Emissions}

For site locations in the United States, if no emission factor selection is made, default emission factors will be used. If the site location is within the continental United States, the default factors used will be the EPA AVERT region corresponding to the location (EPA 2019). If the site is in Hawaii or Alaska, a default annual emission factor used in the evaluation comes from the EPA eGrid database. ${ }^{13}$

For Alaska and Hawaii, eGRID annual average emission factors are used (EPA 2020). eGRID provides grid emission factors by region for the total generation, combustion (fossil fuel) generation, and non-baseload generation. When using eGRID factors for Alaska and Hawaii, we use 'non-baseload' emission factors. This is based on EPA CHP guidance:

When calculating fuel and CO2 emissions savings associated with CHP, the Partnership recommends using the following factors:

- The eGRID all fossil emissions factor and heat rate for the eGRID subregion where the CHP system is located for baseload CHP (i.e., greater than 6,500 annual operating hours), and

- The eGRID non-baseload emissions factor and heat rate for the eGRID subregion where the CHP system is located for CHP systems with relatively low annual capacity factors (i.e., less than 6,500 annual operating hours) and with most generation occurring during periods of high system demand (EPA 2015).

We do not know in advance how many hours the CHP unit will be dispatched. Additionally, in our analysis, we are including CHP and non-CHP generators. The non-CHP generators - wind and PV-have low annual capacity factors so they are not considered baseload generators.

\footnotetext{
${ }^{13}$ https://www.epa.gov/egrid
} 
Therefore, when using eGRID factors for Alaska and Hawaii, we use 'non-baseload' rather than 'all fossil' emission factors since they better reflect the mix of technologies REopt Lite is considering.

The emission factors from eGRID for Alaska and Hawaii are in Table 4.

Table 4. EPA eGRID emission factors, $E_{\mathrm{g}}$, for Alaska and Hawaii

\begin{tabular}{|l|c|c|c|c|c|}
\hline State & $\begin{array}{c}\text { eGRID } \\
\text { Subregion } \\
\text { Acronym }\end{array}$ & $\begin{array}{c}\text { eGRID } \\
\text { Subregion } \\
\text { Name }\end{array}$ & $\begin{array}{c}\text { eGRID Subregion } \\
\text { Annual CO2 Non- } \\
\text { baseload Output } \\
\text { Emission Rate } \\
\text { (Ib/kWh) }\end{array}$ & $\begin{array}{c}\text { T\&D } \\
\text { Losses }\end{array}$ & $\begin{array}{c}\text { eGRID Subregion } \\
\text { Annual Emission } \\
\text { Rate with T\&D } \\
\text { Losses (Ib/kWh) }\end{array}$ \\
\hline Alaska & AKGD & $\begin{array}{c}\text { ASCC } \\
\text { Alaska Grid }\end{array}$ & 1.368 & $5.25 \%$ & 1.444 \\
\hline $\begin{array}{l}\text { Hawaii, } \\
\text { excluding Oahu } \\
\text { Island }\end{array}$ & HIMS & $\begin{array}{c}\text { HICC } \\
\text { Miscellaneous }\end{array}$ & 1.530 & $5.35 \%$ & 1.616 \\
\hline $\begin{array}{l}\text { Hawaii, Oahu } \\
\text { Island }\end{array}$ & HIOA & HICC Oahu & 1.638 & $5.35 \%$ & 1.731 \\
\hline
\end{tabular}

a. Alaska Systems Coordinating Council

b. Hawaiian Islands Coordinating Council

As a user option, a single annual $\mathrm{CO} 2$ grid emission factor, in $1 \mathrm{bs} \mathrm{CO} 2 / \mathrm{kWh}$, can be entered which will be applied to grid-sourced electricity in each hour of the year. Alternatively, the user can upload an hourly emission factor file for a year (8,760 hours).

If the site location is outside the United States, any of the $\mathrm{CO} 2$ emission factor input options can be used. However, if no emission factor selection is made, there is no default value and the $\mathrm{CO} 2$ emissions from the electricity grid will not be calculated.

\subsection{Fuels Emissions}

Emission factors for on-site fuel consumption default to the value appropriate for the userselected fuel type as shown in Table 5.

Table 5. Selected Fuel-Specific Energy and CO2 Emissions Factors

\begin{tabular}{|l|c|}
\hline Fuel Type & CO2 Emissions Factor, Ib./MMBtu \\
\hline Natural Gas $^{\mathrm{a}}$ & 116.9 \\
\hline Landfill gas, other biomass gases $^{\mathrm{b}}$ & 114.8 \\
\hline Propane $^{\mathrm{b}}$ & 138.6 \\
\hline Diesel fuel, No. 2 $^{\mathrm{b}}$ & 163.1 \\
& $(22.51 \mathrm{~b} . /$ gallon $)$ \\
\hline
\end{tabular}

a. EPA 2015

b. EPA 2018

\section{Photovoltaics}

REopt Lite uses NREL's PVWatts application to determine the electricity production of installed PV systems. The amount of electricity produced by the PV array at each time step is proportional to the hourly capacity factor at the site. Because the production of PV arrays tends to decline over their lifespan, and the model only optimizes over one year, REopt Lite uses an average 
annual production profile based on an assumed $0.5 \%$ per-year degradation rate over the analysis period. We assume the inverter is replaced once during the system lifetime, and replacement cost is amortized into annual O\&M costs.

The size of the PV installation is limited by available roof or land space. The default assumption allows one MW-DC of PV to be installed for every six acres of space available, and 10 DC watts per square foot of roof space. Hourly solar radiation data comes from the National Solar Radiation Database, which uses a physics-based modeling approach to provide solar radiation data for the United States in 4-km gridded segments using geostationary satellites. Data for international sites is also available for a growing number of countries as described at https://nsrdb.nrel.gov/about/international-data.html.

Refer to the PVWatts technical reference manual for further modeling assumptions and descriptions (Dobos 2014).

\subsection{PV Costs}

PV system costs include capital cost and O\&M cost. The capital cost represents the fully burdened installed cost, including both equipment and labor. O\&M includes asset cleaning, administration costs, and replacing broken components. It also includes the cost of inverter replacement. Incentives can be applied to reduce the cost; these are described in Section 4.3, Economic Incentives.

\subsection{PV System Characteristics}

\subsubsection{PV Size}

REopt Lite identifies the system size, in $\mathrm{kW}$-DC, that minimizes the life cycle cost of energy at the site. By default, there is no lower or upper limit on the size. If desired, the user can bound the range of sizes considered with a minimum and a maximum size. The minimum new PV size forces a new PV system of at least this size to appear at the site. If there is not enough land available, or if the interconnection limit will not accommodate the system size, the problem will be infeasible.

The maximum new PV size limits the new PV system (not including any existing PV system) to no greater than the specified maximum.

To remove the option of a new PV system from consideration in the analysis, set the maximum size to zero. If a specific-sized system is desired, enter that size as both the minimum size and the maximum size.

The minimum and maximum new PV size limits for technologies are assumed to be in addition to any existing PV; for example, there could be a 10-kW existing PV system, and if the user inputs a maximum new PV size of $2 \mathrm{~kW}$, then the upper limit that will be allowed by REopt Lite is $10+2=12 \mathrm{~kW}$.

\subsubsection{Existing PV}

If the site has an existing PV system, this can be modeled in REopt Lite by entering its size in $\mathrm{kW}$. The existing PV system will be factored into business-as-usual O\&M cost calculations and 
net metering credits and limits. No incentives will be included for the existing PV system. If the user has chosen to optimize for energy resilience, the energy from this existing PV system will be factored into the energy resilience optimization.

When entering existing PV, the user selects how the typical energy load profile will be characterized with the addition of the existing PV system load. The default selection is Net load profile, which is the gross load minus the existing PV generation. The other option is to consider the typical energy load profile that has been entered as the gross load.

\subsubsection{Module Type}

The module type describes the PV modules in the array. If you do not have information about the modules in the system, use the default Standard module type. Otherwise, you can use the nominal module efficiency, cell material, and temperature coefficient from the module data sheet to choose the module type.

Table 6. Module Types

\begin{tabular}{|l|c|c|c|}
\hline Type & $\begin{array}{c}\text { Approximate } \\
\text { Efficiency }\end{array}$ & $\begin{array}{c}\text { Module } \\
\text { Cover }\end{array}$ & $\begin{array}{c}\text { Temperature Coefficient } \\
\text { of Power }\end{array}$ \\
\hline $\begin{array}{l}\text { Standard (crystalline } \\
\text { silicon) }\end{array}$ & $15 \%$ & Glass & $-0.47 \%{ }^{\circ} \mathrm{C}$ \\
\hline $\begin{array}{l}\text { Premium (crystalline } \\
\text { silicon) }\end{array}$ & $19 \%$ & Anti-reflective & $-0.35 \% /{ }^{\circ} \mathrm{C}$ \\
\hline Thin Film & $10 \%$ & Glass & $-0.20 \% /{ }^{\circ} \mathrm{C}$ \\
\hline
\end{tabular}

PVWatts uses a basic set of equations to represent the module's physical properties and performance. The module type determines how PVWatts calculates the angle-of-incidence correction factor as sunlight passes through the module cover to the photovoltaic cell, and the cell's operating temperature. See the PVWatts Technical Reference for details (Dobos 2014).

\subsubsection{Array Type}

The array type describes whether the PV modules in the array are fixed or whether they move to track the movement of the sun across the sky with one or two axes of rotation. Options include Rooftop, Fixed; Ground Mount, Fixed (open rack); and Ground Mount, 1-Axis Tracking. The default value is a rooftop, fixed system. If 0 is entered in the roofspace available input field, the default changes to ground mount, fixed.

For systems with fixed arrays, you can choose between an open rack or a roof mount option. The open rack option is appropriate for ground-mounted systems. It assumes that air flows freely around the array, helping to cool the modules and reduce cell operating temperatures. (The array's output increases as the cell temperature decreases at a given incident solar irradiance.) The roof mount option is typical of residential installations where modules are attached to the roof surface with standoffs that provide limited air flow between the module back and roof surface (typically between two and six inches).

For the open rack option, PVWatts assumes an installed nominal operating temperature of 45 degrees Celsius. For roof mount systems, the installed nominal operating temperature is $50^{\circ} \mathrm{C}$, 
which corresponds roughly to a three- or four-inch standoff height. See the Technical Reference for details (Dobos 2014).

\subsubsection{Array Azimuth}

For a fixed array, the azimuth angle is the angle clockwise from true north describing the direction that the array faces. An azimuth angle of $180^{\circ}$ is for a south-facing array, and an azimuth angle of zero degrees is for a north-facing array. For an array with one-axis tracking, the azimuth angle is the angle clockwise from true north of the axis of rotation.

The default value is an azimuth angle of $180^{\circ}$ (south-facing) for locations in the northern hemisphere. This value typically maximizes electricity production over the year, although local weather patterns may cause the optimal azimuth angle to be slightly more or less than the default values. For the northern hemisphere, increasing the azimuth angle favors afternoon energy production, and decreasing the azimuth angle favors morning energy production.

Table 7. Azimuth Angles for Different Compass Headings

\begin{tabular}{|l|c|}
\hline Heading & Azimuth Angle \\
\hline N & $0^{\circ}$ \\
\hline NE & $45^{\circ}$ \\
\hline E & $90^{\circ}$ \\
\hline SE & $135^{\circ}$ \\
\hline S & $180^{\circ}$ \\
\hline SW & $225^{\circ}$ \\
\hline W & $270^{\circ}$ \\
\hline NW & $315^{\circ}$ \\
\hline
\end{tabular}

The maximum number entered must be less than or equal to 360 - an error will display if a higher value is entered.

\subsubsection{Array Tilt}

The tilt angle is the angle from horizontal of the PV modules in the array. For a fixed array, the tilt angle is the angle from horizontal of the array where $0^{\circ}=$ horizontal, and $90^{\circ}=$ vertical. For arrays with one-axis tracking, the tilt angle is the angle from horizontal of the tracking axis.

By default, REopt Lite sets the tilt angle to 10 degrees for a rooftop system, equal to the site's latitude for a ground mount fixed system, and to 0 degrees for a one axis tracking system. Setting the tilt equal to the latitude does not necessarily maximize the net annual output of the system, as lower tilt angles favor peak production in the summer months and higher tilt angles favor lower irradiance conditions in the winter months. Designers often use a lower tilt angle to minimize the cost of racking and mounting hardware, or to minimize the risk of wind damage to the array.

In general, using a tilt angle greater than the location's latitude favors energy production in the winter and using a tilt angle less than the location's latitude favors energy production in the summer. 
For a PV array on a building's roof, you may want to choose a tilt angle equal to the roof pitch. Use Table 8 to convert roof pitch in ratio of rise (vertical) over run (horizontal) to tilt angle.

Table 8. PV Array Tilt Angle for Different Roof Pitches

\begin{tabular}{|l|c|}
\hline $\begin{array}{l}\text { Roof Pitch } \\
\text { (Rise/Run) }\end{array}$ & Tilt Angle \\
\hline $4 / 12$ & $18.4^{\circ}$ \\
\hline $5 / 12$ & $22.6^{\circ}$ \\
\hline $6 / 12$ & $26.6^{\circ}$ \\
\hline $7 / 12$ & $30.3^{\circ}$ \\
\hline $8 / 12$ & $33.7^{\circ}$ \\
\hline $9 / 12$ & $36.9^{\circ}$ \\
\hline $10 / 12$ & $39.8^{\circ}$ \\
\hline $11 / 12$ & $42.5^{\circ}$ \\
\hline $12 / 12$ & $45^{\circ}$ \\
\hline
\end{tabular}

The maximum number entered must be less than or equal to 90 - an error will display if a higher value is entered.

\subsubsection{Direct Current to Alternating Current Size Ratio}

The direct current (DC) to alternating current (AC) size ratio is the ratio of the inverter's AC rated size to the array's DC rated size. Increasing the ratio increases the system's output over the year, but also increases the array's cost. The default value is 1.20 , which means that a 4-kW system size would be for an array with a $4 \mathrm{DC} \mathrm{kW}$ nameplate size at standard test conditions and an inverter with a $4 \mathrm{DC} \mathrm{kW/1.2}=3.33 \mathrm{AC} \mathrm{kW}$ nameplate size.

For a system with a high DC to AC size ratio, during times when the array's DC power output exceeds the inverter's rated DC input size, the inverter limits the array's power output by increasing the DC operating voltage, which moves the array's operating point down its currentvoltage curve. PVWatts models this effect by limiting the inverter's power output to its rated AC size.

The default value of 1.20 is reasonable for most systems. A typical range is 1.10 to 1.25 , although some large-scale systems have ratios of as high as 1.50. The optimal value depends on the system's location, array orientation, and module cost. The maximum number entered must be less than or equal to 2 - an error will display if a higher value is entered.

\subsubsection{System Losses}

The system losses account for performance losses you would expect in a real system that are not explicitly calculated by the PVWatts model equations. The default value for the system losses of $14 \%$ is based on the categories in the table below, and calculated as follows:

$$
\begin{aligned}
& 100 \% *(1-(1-0.02) *(1-0.03) *(1-0.02) *(1-0.02) *(1-0.005) *(1-0.015) *(1- \\
& 0.01) *(1-0.03))=14 \%
\end{aligned}
$$


The inverter's DC-to-AC conversion efficiency is a separate, non-adjustable input with a value of $96 \%$. Do not include inverter conversion losses in the system loss percentage. PVWatts calculates temperature-related losses as a function of the cell temperature, so you should not include a temperature loss factor in the system loss percentage. See the PVWatts Technical Reference for details (Dobos 2014).

Table 9. Default Values for the System Loss Categories

\begin{tabular}{|l|c|}
\hline Category & Default Value (\%) \\
\hline Soiling & 2 \\
\hline Shading & 3 \\
\hline Snow & 0 \\
\hline Mismatch & 2 \\
\hline Wiring & 2 \\
\hline Connections & 0.5 \\
\hline Light-Induced Degradation & 1.5 \\
\hline Nameplate Rating & 1 \\
\hline Age & 0 \\
\hline Availability & 3 \\
\hline
\end{tabular}

The maximum number entered must be less than or equal to 99-an error will display if a higher value is entered.

\section{Battery Storage}

Battery energy storage is modeled as a "reservoir" in REopt Lite-energy produced during one time step can be consumed during another. REopt Lite does not explicitly model battery chemistries, but rather includes parameters for cost, efficiency, and SOC that can be adjusted to reflect different chemistries. The default values are representative of lithium-ion batteries. The model selects and sizes both the capacity of the battery in $\mathrm{kWh}$ and the power delivery in $\mathrm{kW}$ $\mathrm{AC}$. The battery power $(\mathrm{kW}-\mathrm{AC})$ and capacity $(\mathrm{kWh})$ are independently optimized for economic performance (and resiliency, if resiliency requirements are specified) - a power-to-energy ratio is not predefined. By default, any technology can charge the energy storage device, but charging can also be limited to specific technologies.

Energy storage technologies are modeled to capture revenue from multiple value streams: performing energy arbitrage, time-shifting excess renewable energy production, and reducing demand charges or "peak shaving." The user can define the battery energy storage model characteristics including minimum SOC, initial SOC, efficiencies, minimum size, maximum size, capital cost, and replacement cost. The user can also decide whether or not the grid can be used to charge the battery. Battery cycling degradation is not included in the model; rather, we assume the battery will be replaced once during the analysis period (in year ten by default) based on calendar degradation, and include amortized replacement costs in the model. These inputs are described in more detail below. 


\subsection{Battery Cost}

\subsubsection{Capital Cost}

Battery cost is defined by two parameters: energy capacity cost $(\$ / \mathrm{kWh})$ and power capacity cost $(\$ / \mathrm{kW})$. These costs are additive.

Energy capacity cost is the cost of the energy components of the battery system (e.g., battery pack). Power capacity cost is the cost of the power components and interconnection of the battery system (e.g., inverter and balance of system). The amount of energy that a battery can store is determined by its capacity $(\mathrm{kWh})$ while the rate at which it charges or discharges is determined by its power rating $(\mathrm{kW})$. While PV system cost is typically estimated based on power rating $(\mathrm{kW})$ alone, battery costs are estimated based on both capacity $(\mathrm{kWh})$ and power $(\mathrm{kW})$.

The power components of the system (e.g., inverter, balance of system) are captured by the power metric of $\$ / \mathrm{kW}$ and the energy components of the system (e.g., battery) are captured by the energy metric of $\$ / \mathrm{kWh}$. This allows the capacity $(\mathrm{kWh})$ and power $(\mathrm{kW})$ rating of the battery to be optimized individually for maximum economic performance based on the load, rate tariff, and resiliency requirements of the site. Some systems are optimized to deliver high power capacity $(\mathrm{kW})$, while others are optimized for longer discharges through more energy capacity $(\mathrm{kWh})$.

For example, assume the unit cost of power components is $\$ 1,000 / \mathrm{kW}$, and the unit cost of energy components is $\$ 500 / \mathrm{kWh}$. Consider a battery with $5 \mathrm{~kW}$ of power capacity and $10 \mathrm{kWh}$ of energy capacity $(5 \mathrm{~kW} / 10 \mathrm{kWh})$. The total cost of the battery would be:

$$
(5 \mathrm{~kW} * \$ 1,000 / \mathrm{kW})+(10 \mathrm{kWh} * \$ 500 / \mathrm{kWh})=\$ 10,000
$$

\subsubsection{Replacement Cost}

Replacement costs are similarly defined by energy capacity and power capacity costs, as well as replacement year. They are the expected cost, in today's dollars, of replacing the energy components of the battery system (e.g., battery pack) and power components of the battery system (e.g., inverter, balance of systems), respectively, during the project life cycle.

Replacement year is the year in which the energy or power components of the battery system are replaced during the project life cycle; the default is Year 10.

\subsubsection{Allowing Grid to Charge Battery}

REopt Lite allows the user to specify whether the utility grid can be used to charge the battery. If this input is set to no, the grid cannot charge the battery. Only the renewable energy system will charge the battery. If it is set to yes, either the grid or the renewable energy system can charge the battery. The default is set to yes in order to allow evaluation of batteries that are not connected to a renewable energy system.

Whether or not the grid charges the battery impacts the owner's ability to take advantage of the federal ITC and MACRS. The 2020 federal $26 \%$ ITC is generally understood to be available to batteries charged $100 \%$ by eligible renewable energy technologies, including solar and wind, when they are installed as part of a renewable energy system. Batteries charged by a renewable 
energy system $75 \%-99 \%$ of the time are eligible for that portion of the ITC. For example, a system charged by renewable energy $80 \%$ of the time is eligible for the $26 \%$ ITC multiplied by $80 \%$, which equals a $20.8 \%$ ITC instead of $26 \%$.

Without a renewable energy system installed, battery systems are eligible for the seven-year MACRS depreciation schedule - an equivalent reduction in capital cost of about $20 \%$ (assuming a $26 \%$ federal tax rate and an $8 \%$ discount rate). The same benefit applies to battery systems installed along with a renewable energy system if the battery is charged by the renewable energy system less than $75 \%$ of the time. If the battery system is charged by the renewable energy system more than $75 \%$ of the time on an annual basis, the battery should qualify for the five-year MACRS schedule, equal to about a $21 \%$ reduction in capital costs.

When claiming the ITC, the MACRS depreciation basis is reduced by half of the value of the ITC. Note new tax laws concerning battery systems are pending. Refer to the Internal Revenue Service for the latest regulations.

\subsection{Battery Characteristics}

\subsubsection{Battery Size}

REopt Lite identifies the system size that minimizes the life cycle cost of energy at the site. By default, there is no lower or upper limit on size. If desired, the user can bound the range of sizes considered with a minimum and maximum size. The minimum energy capacity size forces a battery energy capacity of at least this size to appear at a site. The maximum energy capacity size limits the battery energy capacity to no greater than the specified maximum.

To remove a technology from consideration in the analysis, set the maximum size to zero. If a specific sized system is desired, enter that size as both the minimum size and the maximum size.

An existing battery size cannot be specified.

\subsubsection{Battery Efficiency}

The efficiency of the battery is defined by three components:

- Rectifier efficiency: The rectifier's nominal rated AC-to-DC conversion efficiency, defined as the rectifier's rated DC power output divided by its rated AC power output. The default value is $96 \%$.

- Round trip efficiency: This is the ratio of the DC power put into a battery to the DC power retrieved from the same battery. The default value is $97.5 \%$.

- Inverter efficiency: The inverter's nominal rated DC-to-AC conversion efficiency, defined as the inverter's rated AC power output divided by its rated DC power output. The default value is $96 \%$.

The product of these three efficiencies provides the total $\mathrm{AC}-\mathrm{AC}$ round trip efficiency, which is the ratio of the $\mathrm{AC}$ power put into a battery to the $\mathrm{AC}$ power retrieved from the same battery. The default value is $89.9 \%$. Note that the round-trip efficiency only accounts for DC power in and out of the battery, while the total AC-AC round trip efficiency also accounts for the need to 
convert $\mathrm{AC}$ power to $\mathrm{DC}$ in order to charge the battery, and $\mathrm{DC}$ power to $\mathrm{AC}$ in order to discharge the battery.

\subsubsection{Battery State of Charge}

The user can enter a minimum SOC to define the lowest desired level of charge of the battery. The default is $20 \%$.

The user can also enter the initial SOC of the battery at the beginning of the analysis period. The default is $50 \%$.

\section{Wind Turbine}

REopt Lite models wind turbines of four different sizes: residential $(<20 \mathrm{~kW})$, commercial $(21-$ $100 \mathrm{~kW})$, midsize $(101-999 \mathrm{~kW})$, and large $(\geq 1000 \mathrm{~kW})$. Turbine sizes and power curves for each size class are shown below.

REopt Lite uses the site location and the wind size class selected to access wind resource data from the Wind Integration National Dataset (WIND) Toolkit. The WIND Toolkit includes meteorological conditions and turbine power for more than 126,000 sites in the continental United States for the years 2007-2013. REopt Lite uses 2012 data because it is close to the WIND Toolkit overall average wind generation across 2007-2013.

The WIND Toolkit provides wind speed, air pressure, air temperature, and wind direction at an hourly resolution. These values returned by the WIND Toolkit are processed by the System Advisor Model (SAM) to produce the wind energy production curves used for the optimization. ${ }^{14}$ Refer to the WIND Toolkit technical reference manual for further modeling assumptions and descriptions (Draxl et al 2015).

Wind projects exceeding 1.5 MW are constrained by land availability when this information is provided, assuming a power density of 30 acres per MW.

\subsection{Wind Cost}

Wind turbine costs include capital cost and O\&M cost. The capital cost represents the fully burdened cost of installed wind system in dollars per kilowatt. The chart below gives the default system capital costs that are used by REopt Lite for each wind size class. If a custom cost is entered, it will be used instead of the default cost.

Table 10. Wind Capital Cost Default Values

\begin{tabular}{|l|c|c|c|c|}
\hline Size Class & $\begin{array}{c}\text { System Size } \\
(\mathbf{k W}-\mathbf{A C})\end{array}$ & $\begin{array}{c}\text { Base Cost } \\
\mathbf{( \$ / \mathbf { k } )}\end{array}$ & $\begin{array}{c}\text { Hub Height } \\
\mathbf{( m )}\end{array}$ & $\begin{array}{c}\text { Rotor } \\
\text { Radius } \mathbf{( m )}\end{array}$ \\
\hline Residential & 2.5 & $\$ 11,950$ & 20 & 1.85 \\
\hline Commercial & 100 & $\$ 7,390$ & 40 & 13.8 \\
\hline Midsize & 250 & $\$ 4,440$ & 50 & 21.9 \\
\hline Large & 2,000 & $\$ 3,450$ & 80 & 55 \\
\hline
\end{tabular}

\footnotetext{
${ }^{14}$ https://sam.nrel.gov/
} 
The O\&M cost includes asset cleaning, administration costs, and replacing broken components. Incentives can be applied to reduce the cost; these are described in 4.3, Economic Incentives.

\subsection{Wind characteristics}

\subsubsection{Size Class}

The wind size class selected will determine the potential wind energy production for the site location. The size class should be selected based on site load and wind resource. The size class label refers only to the turbine size, as determined by the rated capacity (or system size), and not the end-use sector. For example, residential sized turbines are often used in commercial applications. REopt Lite models wind turbines of four different sizes:

- Large $(>=1000 \mathrm{~kW}-\mathrm{AC})$

- $\quad$ Midsize (101-999 kW-AC)

- Commercial (21-100 kW-AC)

- Residential (0-20 kW-AC).

Table 11 provides the representative turbine sizes used by REopt Lite for each wind size class. For the optimization, a single turbine installation is generally assumed.

Table 11. Wind Size Class Representative Sizes

\begin{tabular}{|l|c|c|c|}
\hline Size Class & $\begin{array}{c}\text { System Size } \\
(\mathbf{k W - A C})\end{array}$ & $\begin{array}{c}\text { Hub Height } \\
(\mathbf{m})\end{array}$ & $\begin{array}{c}\text { Rotor } \\
\text { Radius (m) }\end{array}$ \\
\hline Residential & 2.5 & 20 & 1.85 \\
\hline Commercial & 100 & 40 & 13.8 \\
\hline Midsize & 250 & 50 & 21.9 \\
\hline Large & 2,000 & 80 & 55 \\
\hline
\end{tabular}

The representative power curves are based on Lantz et al. (2016) but assume near-future turbine technology advancements. 
Table 12. Representative Power Curves

\begin{tabular}{|l|c|c|c|c|}
\hline & Residential (2.5kW) & Commercial (100kW) & Midsize (250kW) & Large (2000kW) \\
\hline Wind Speed (m/s) & $\mathbf{k W}$ & $\mathbf{k W}$ & $\mathbf{k W}$ & $\mathbf{k W}$ \\
\hline $\mathbf{2}$ & 0 & 0 & 0 & 0 \\
\hline $\mathbf{3}$ & 0.070542773 & 3.50595 & 8.764875 & 70.119 \\
\hline $\mathbf{4}$ & 0.1672125 & 8.3104 & 20.776 & 166.208 \\
\hline $\mathbf{5}$ & 0.326586914 & 16.23125 & 40.578125 & 324.625 \\
\hline $\mathbf{6}$ & 0.564342188 & 28.0476 & 70.119 & 560.952 \\
\hline $\mathbf{7}$ & 0.896154492 & 44.53855 & 111.346375 & 890.771 \\
\hline $\mathbf{8}$ & 1.3377 & 66.4832 & 166.208 & 1329.664 \\
\hline $\mathbf{9}$ & 1.904654883 & 94.66065 & 236.651625 & 1893.213 \\
\hline $\mathbf{1 0}$ & 2.5 & 100 & 250 & 2000 \\
\hline
\end{tabular}

Source: Lantz et al. (2016)

If no wind size class is selected, the default wind class value of 'commercial' will be used.

The selection of a size class does not limit the minimum and maximum sizes considered in the optimization to that range; the optimization may recommend a wind capacity that is outside of the range of sizes defined by the selected size class. In this case, the production and cost data used in the model may not apply to the system size recommended. For example, if the user selects the large size class $(>1000 \mathrm{~kW})$ but gets a recommendation for a $50-\mathrm{kW}$ wind turbine, the recommended $50-\mathrm{kW}$ turbine was incorrectly costed at the cheaper large-class cost and its production estimate used the superior wind resource of a taller large-class turbine.

If the results recommend a wind turbine in a different size class than that selected, the results will be flagged and the user can iterate on the analysis inputs, updating the size class and rerunning the optimization.

\subsubsection{Wind Size}

REopt Lite identifies the system size that minimizes the life cycle cost of energy at the site. By default, there is no lower or upper limit on size. If desired, the user can bound the range of sizes considered with a minimum and maximum size. If there is not enough land available, or if the interconnection limit will not accommodate the system size, the problem will be infeasible.

To remove a technology from consideration in the analysis, set the maximum size to zero. If a specific sized system is desired, enter that size as both the minimum size and the maximum size.

\section{Backup Diesel Generator}

REopt Lite models a reciprocating engine that consumes fuel and generates electricity. The fuel consumption is modeled using a linear fuel curve as described for the CHP generator in Section 14.2, CHP Fuel Consumption, and is limited to the fuel availability entered by the user. REopt Lite can model a minimum turndown, meaning the generator can operate at partial loading down to a given fraction of its nameplate capacity; any lower and it must shut off. By default, the generator's minimum turndown percent is set to zero to enable it to operate at the full range of capacity $(0 \%-100 \%)$ during an outage. 
By default, generators only operate during grid outages. The production factor of the diesel generator is zero for all hours of the year except during the user-specified outage period, which essentially models it as a backup generation resource. This assumption can be changed in the API to allow the generator to operate while grid-connected, but not in the web interface.

\subsection{Generator Costs}

Generator costs include the installed cost, O\&M cost, and diesel fuel cost. The capital cost represents the fully burdened installed cost, including both equipment and labor. O\&M includes fixed regular O\&M based on calendar intervals including testing, stored fuel maintenance, and service contracts. Variable O\&M includes non-fuel O\&M costs which vary with the amount of electricity produced. Variable O\&M may include filters and oil changes, and other maintenance requirements based on engine run-hours.

Diesel fuel cost is input separately in units of dollars per gallon. Fuel availability represents the amount of fuel available on-site for new and existing generators. Fuel resupply is not modeled; the generator can no longer run after available fuel is expended.

\subsection{Generator Characteristics}

\subsubsection{Generator Size}

REopt Lite identifies the system size in $\mathrm{kW}-\mathrm{AC}$ that minimizes the life cycle cost of energy while meeting the critical load during the specified grid outage at the site. By default, there is no lower or upper limit on the size. If desired, the user can bound the range of sizes considered with a minimum and a maximum size. The minimum new generator size forces a new generator system of at least this size to appear at the site. The maximum new generator size limits the new generator system (not including any existing generator) to no greater than the specified maximum.

To remove the option of a new generator system from consideration in the analysis, set the maximum size to zero. If a specific sized system is desired, enter that size as both the minimum size and the maximum size.

The minimum and maximum new generator size limits are assumed to be in addition to any existing generator; for example, there could be a $10-\mathrm{kW}$ existing generator, and if the user inputs a maximum new generator size of $2 \mathrm{kw}$; then the upper limit that will be allowed by REopt Lite is $10+2=12 \mathrm{~kW}$.

\subsubsection{Existing Diesel Generator}

If the site has an existing generator, this can be modeled in REopt Lite by entering its size in $\mathrm{kW}$. The existing generator will be factored into business-as-usual O\&M cost calculations the energy resilience optimization.

\section{Combined Heat and Power}

This section describes modeling and assumptions for the CHP prime mover and heat recovery system. If the user is considering CHP, assumptions include the following: 
1. There is a central heating plant and heat distribution system that the CHP system can tie into. REopt Lite does not size nor cost a conventional heating plant and heating distribution piping.

2. There is an existing fuel supply and the fuel is costed on a per-unit-of-consumption basis. There are no embedded cost assumptions for adding fuel supply infrastructure (pipeline, storage tanks, fuel pretreatments) or increasing the capacity of the fuel supply infrastructure.

3. The CHP system can operate parallel to the serving utility, providing some, all, or none of the electrical demand in any hour. The exception to this is during a resilience analysis when a power outage is simulated. Then, the critical electrical load identified by the user must be met by the CHP unit and any other sources considered for inclusion, without the utility.

4. The CHP system can serve some, all, or none of the heating load in any hour. There is no requirement that the CHP system serve all of the heating load.

5. If there is excess available heat from the CHP plant, that heat can be dumped to the atmosphere either through a generator exhaust bypass configuration or utilization of a heat exchanger unit.

6. The facility has space to install any selected system. Costs for construction of a building to house a new CHP system are not included beyond basic container costs that may be included in the total installed costs assumptions.

Default performance parameters are available for three different natural gas-fueled CHP prime mover types: reciprocating engine, microturbine, and combustion turbine. Defaults are described in Section 14.8, Default CHP Cost and Performance Parameters by Prime Mover Type and Size Class.

Each of these CHP systems has the same set of inputs which characterize installed system cost, O\&M cost, electric production performance, heat recovery performance, and other constraints. The user may use defaults provided and shown in the user interface or adjust them to reflect details of the system performance and cost under consideration.

\subsection{CHP Prime Mover Overview}

REopt Lite considers CHP system sizes in the range of 1 to $20 \mathrm{MW}(20,000 \mathrm{~kW})$. The CHP performance model is a generalized description of the relations of CHP outputs of power and heat to the input of fuel. These relations are linearized and capture fuel consumption and available recoverable heat as a function of the CHP prime mover's electric loading. Default CHP performance parameters are included within the model for the following prime movers:

1. Reciprocating engine

2. Combustion turbine

3. Microturbine

4. Fuel cell (to be added in a later release) 
5. Steam turbine (to be added in a later release)

All prime movers are topping cycles except the steam turbine which is a bottoming cycle. The steam turbine will be added in a later release. For the topping cycles, fuel is consumed in the generation of electricity while excess heat from combustion (or chemical reaction in the fuel cell) can be captured to served site thermal loads.

The user can use the default parameters provided or modify them to represent the performance of a system of their own specification, selection, or design.

Figure 2 illustrates the energy flows for the topping cycle CHP units. Fuel is converted to electricity and recoverable usable heat.

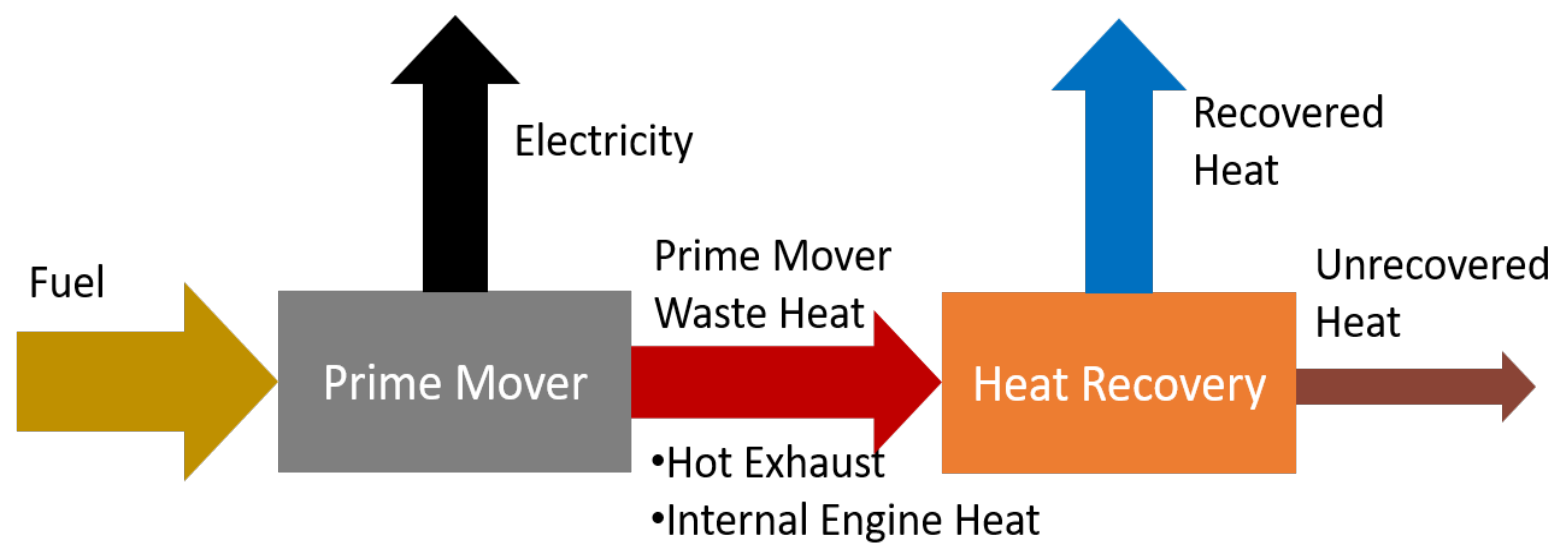

Figure 2. Topping cycle CHP diagram to illustrate the energy flows

This recovered heat can be in the form of hot water or steam. In REopt Lite, thermal loads are assumed to be either hot water or steam. Systems that serve both hot water and steam loads are not modeled.

\subsection{CHP Fuel Consumption}

CHP fuel options include natural gas, propane, diesel, and biogas. The user-selected fuel type impacts $\mathrm{CO} 2$ emissions accounting.

The model for topping cycle prime movers uses a linear equation for fuel burn rate as a function of power generation. Figure 3 shows the relationship of fuel burn rate and fuel efficiency as a function of generator power output for a representative packaged CHP unit ${ }^{15}$ selected from the DOE eCatalog for packaged CHP units (Lawrence Berkeley National Laboratory 2019).

${ }^{15}$ https://chp.ecatalog.lbl.gov/package/10-SP4-ZC90001 


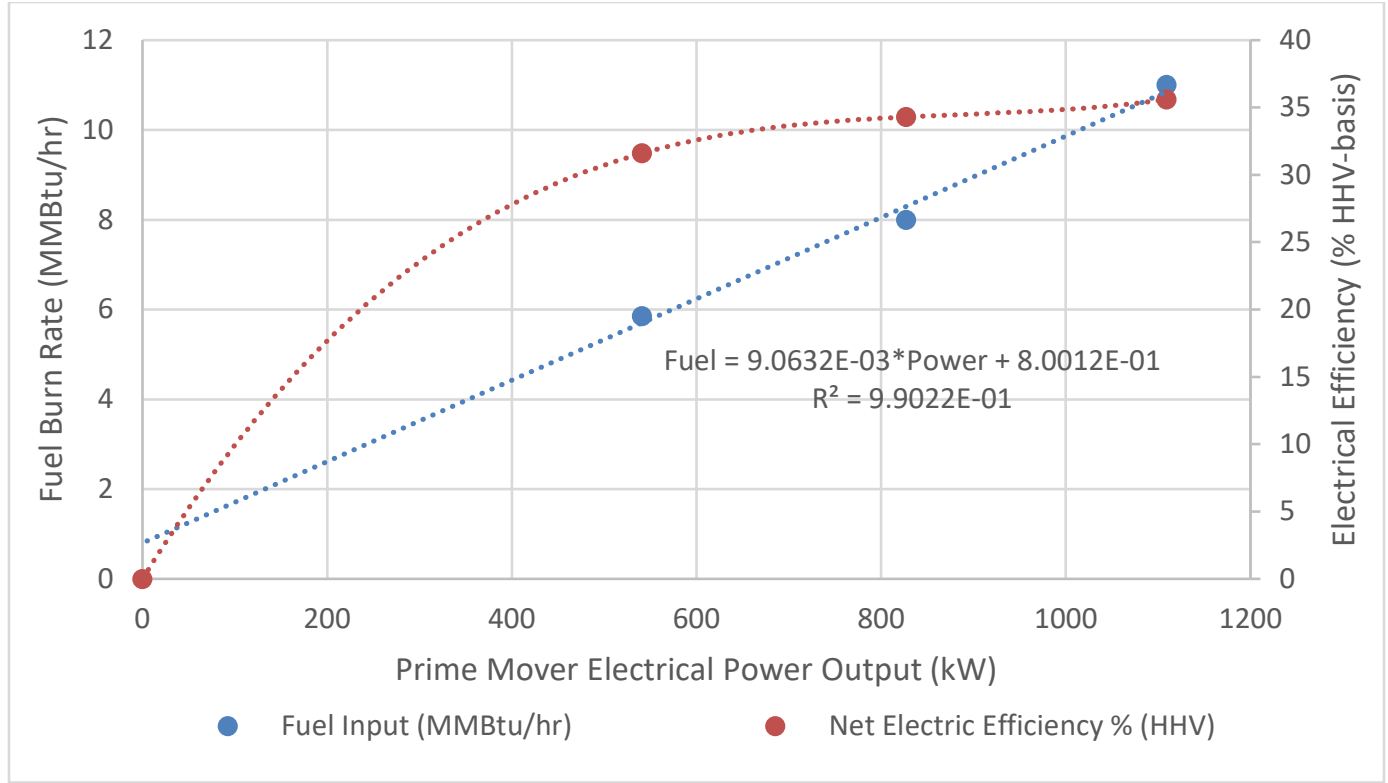

Figure 3. Modeling of CHP fuel burn rate

The figure shows the electrical generation efficiency plotted on the secondary Y-axis versus load as provided. The nonlinear shape of electrical efficiency is typical, with zero efficiency at no load, poor efficiency at low load, and efficiency increasing to a maximum near or at full load. Electric efficiency is defined as:

$$
\text { Electric Efficiency }=\frac{\text { power output }}{\text { fuel consumption rate }} \quad \text { Equation } 5
$$

This variable efficiency is accurately modeled by use of the linear equation fit to the fuel burn rate $(\mathrm{MMBtu} / \mathrm{hr})$ versus load data also provided. As can be seen in the figure, the fuel burn rate can be accurately modeled this way (R-fit in this example is $99 \%$ ). The fuel burn rate equation is:

$$
\text { Fuel Rate }=m_{f} * \text { Power }+b_{f}[\text { MMBtu fuel } / \mathrm{hr}] \quad \text { Equation } 6
$$

The parameters $m_{f}$ and $b_{f}$ are calculated within the model using electrical efficiency of the prime mover at $100 \%$ load and $50 \%$ load since it is expected that these values are more readily available and less likely to be mis-entered than fuel burn rates. These efficiency points are converted to a normalized fuel burn rate (normalized based on rated electric capacity of the prime mover) to get a linear performance curve.

Electrical efficiency, and therefore the parameters $m$ and $b$, will vary depending on the prime mover type and size of the prime mover with electrical efficiency generally increasing with increasing rated power.

REopt Lite includes default values for full load and half load electrical efficiency for various prime movers. These defaults are based on DOE fact sheets, review of eCatalog packaged CHP units, and technical specifications of various commercially available units. Performance is generally reported at some standard operating conditions, typically International Organization for 
Standardization (ISO) reference temperature and atmospheric pressure. ${ }^{16}$ Users should consider how performance may differ for the site specified and modify defaults as appropriate with consultation of subject matter experts.

\subsection{CHP Available Heat Production}

In a topping cycle, the balance of the fuel that is not converted to electricity becomes heat. In a system that generates only electricity, the heat is not useful. In a CHP system, some of this waste heat is recovered to become useful for serving facility heating loads. The level of waste heat recovery depends on both the prime mover type and design choices of the CHP system developer. In REopt Lite the maximum available rate of heat recovery from the system is modeled similarly to fuel burn rate. Figure 4 shows the available heat from the same CHP system shown in Figure 3. The efficiency of heat recovery is shown on the secondary Y-axis and the available recoverable heat is shown on the primary axis. The equation for heat recovery efficiency is:

$$
\text { Heat Recovery Efficiency }=\frac{\text { Heat available output }}{\text { fuel consumption rate }} \quad \text { Equation } 7
$$

The available useful heat is modeled as:

$$
\text { Available Useable Heat }=m_{h} * \text { Power }+b_{h}[\text { MMBtu heat } / h r] \quad \text { Equation } 8
$$

The parameters $m_{h}$ and $b_{h}$ are calculated within REopt Lite using heat recovery efficiency at $100 \%$ load and $50 \%$ load. These parameters are determined from CHP system specifications.

${ }^{16} \mathrm{ISO}$ conditions are $59^{\circ} \mathrm{F}$ and 1 atmosphere for combustion turbines and $77^{\circ} \mathrm{F}$ and 1 atmosphere for reciprocating engines. 


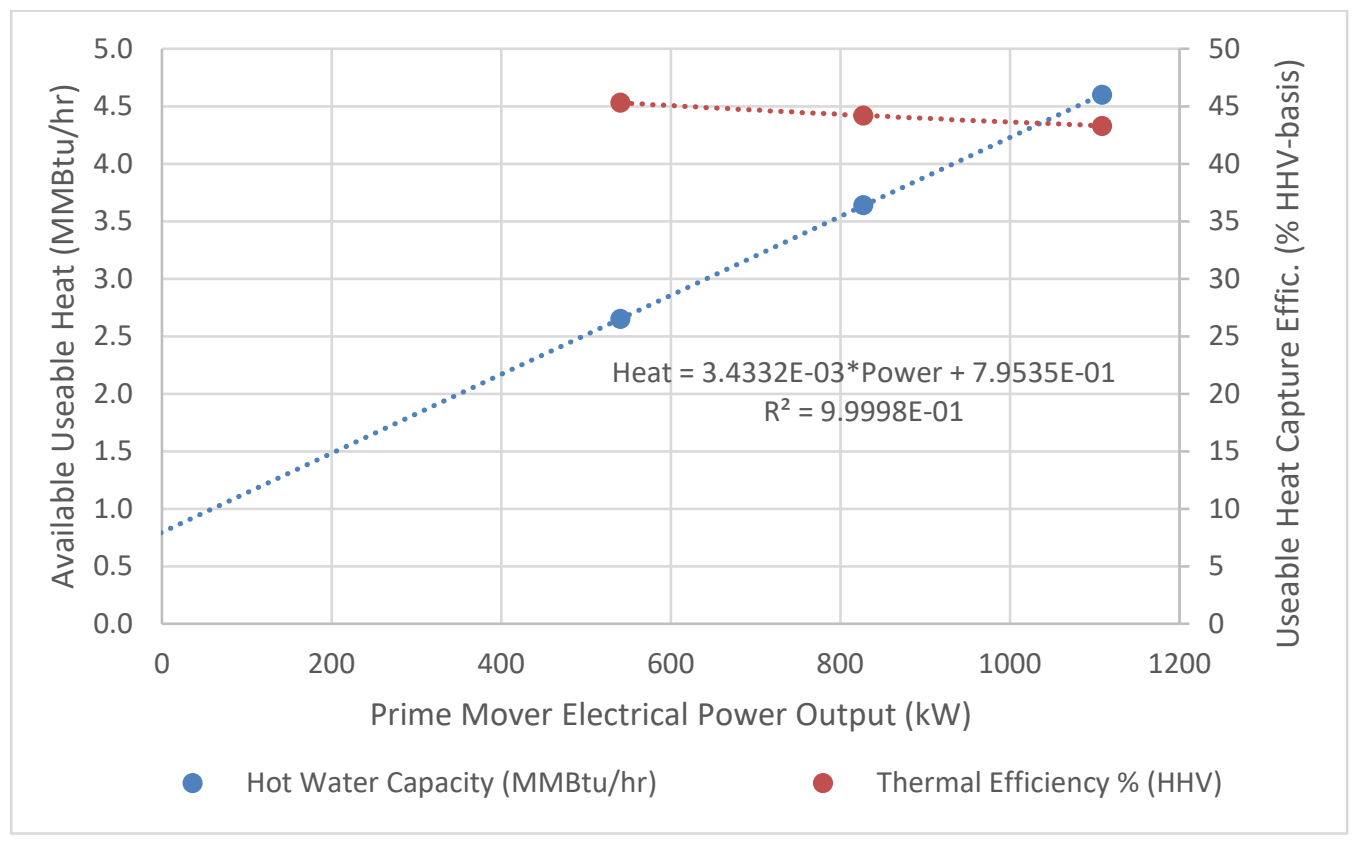

Figure 4. Modeling of CHP available useful heat

The heat recovery is described in terms of 'maximum availability' as we assume that if available heat is not needed, it can be rejected to atmosphere. That is, all, some, or none of the available heat can be used in any time step when the CHP unit is operating.

The level of heat available depends on the load, prime mover type, each vendor's heat recovery system design, and the process heat load conditions, e.g., hot water or steam. Default values for maximum available heat at full and half load are provided for the four prime mover types.

A representative heat recovery system schematic is shown for the default reciprocating engine CHP unit in Figure 5. Figure 6 shows the assumed heat recovery configuration for a microturbine and Figure 7 shows a combustion turbine. Heat recovery configuration for a combustion turbine is similar to that shown for the microturbine although the default performance parameters included in REopt Lite for the combustion turbine are based on a unit without a recuperator. 


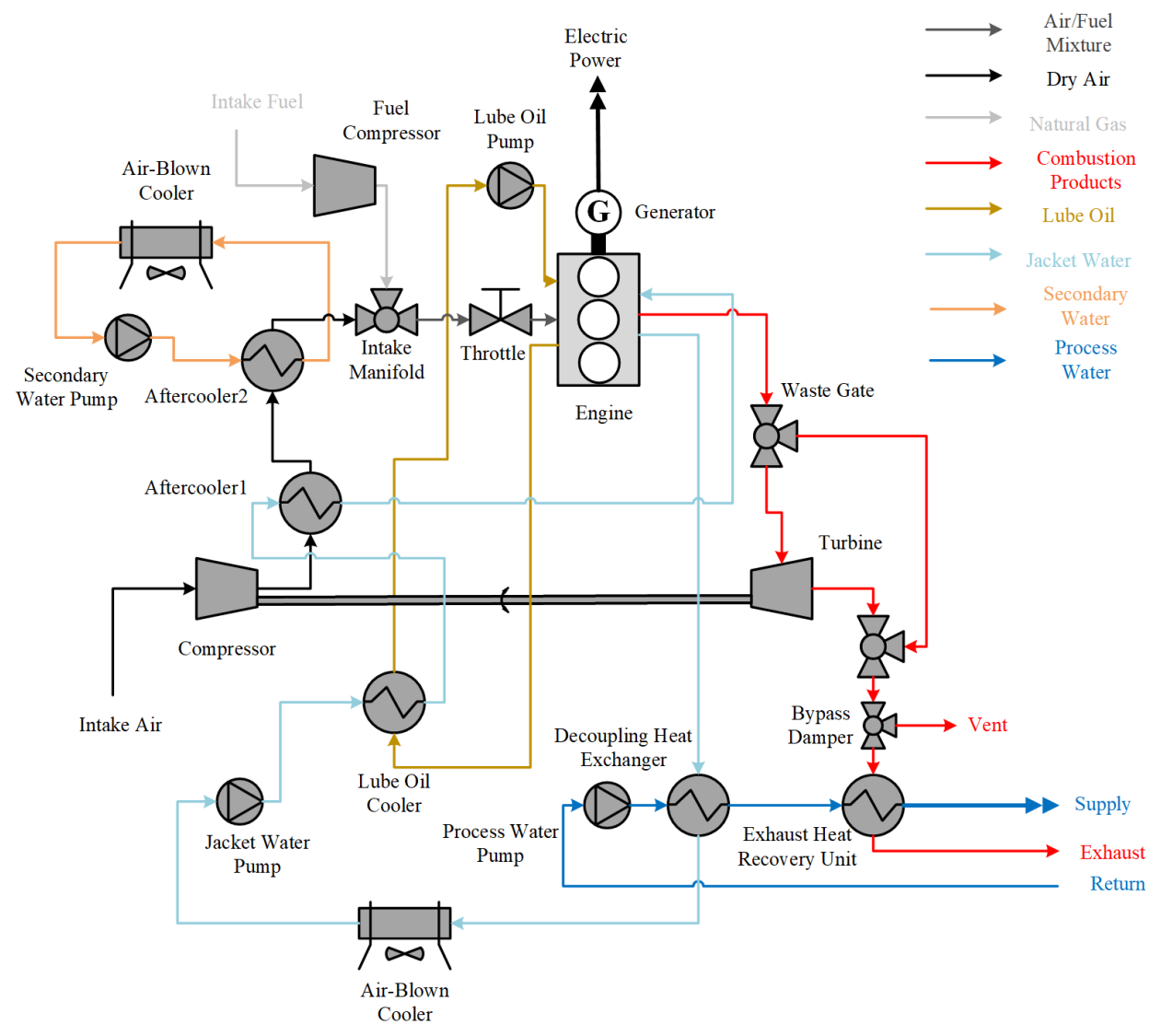

Figure 5. Heat recovery configuration for reciprocating engine CHP

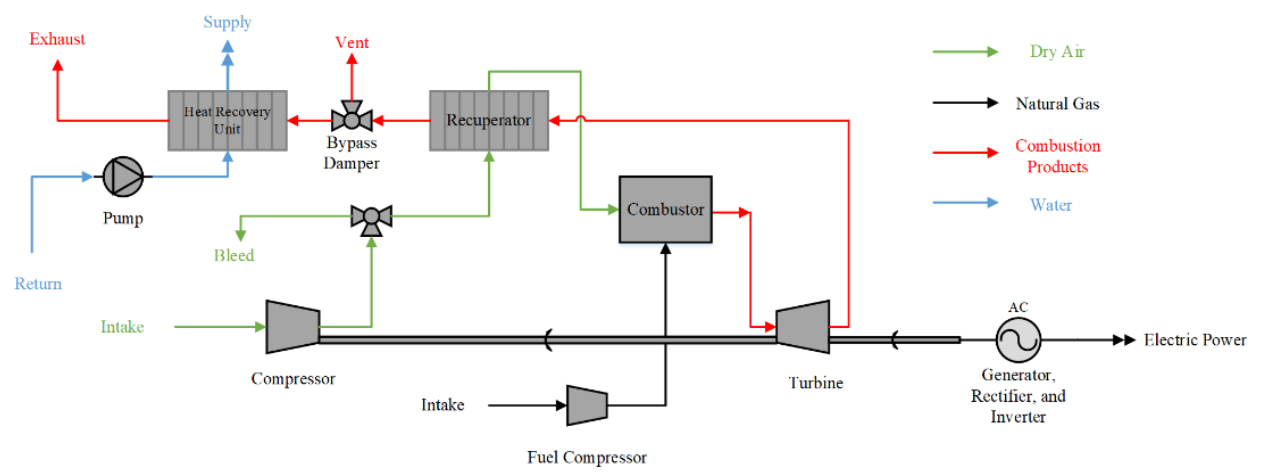

Figure 6. Heat recovery configuration for microturbine CHP 


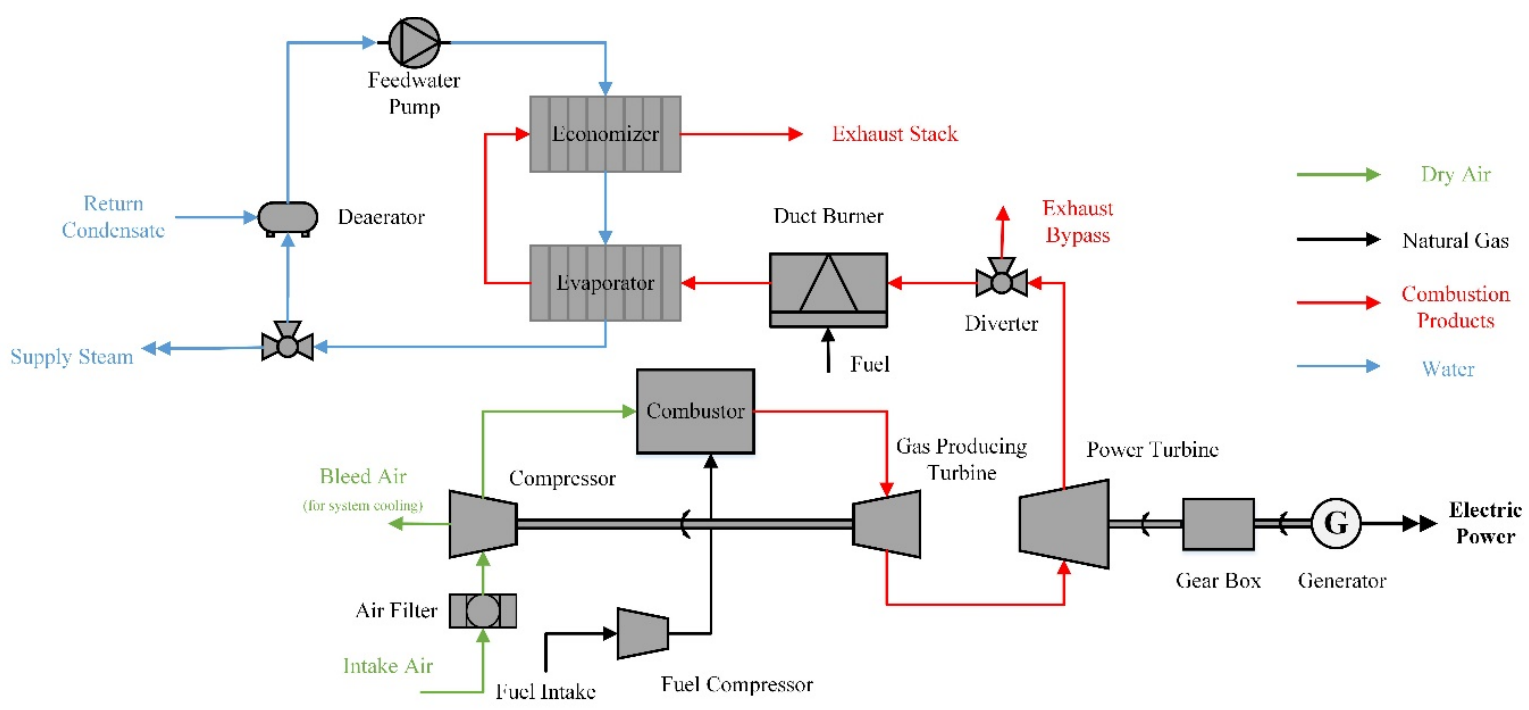

Figure 7. Heat recovery configuration for combustion turbine CHP

Default performance and costs are included in Section 14.8 Default CHP Cost and Performance Parameters by Prime Mover Type and Size Class.

As previously described, performance data is generally provided by CHP equipment providers at some specific conditions, e.g., standard ISO conditions. Additionally, vendor-reported heat recovery values are based on some specific process heat conditions, e.g., some fixed water temperatures, water flow rates, or steam pressures.

\subsection{Modeling Multiple Ganged Units}

Designers will at times build a CHP system from multiple smaller prime movers that can then operate as a unit to provide greater maximum rated power and lower minimum turndown levels. In REopt Lite, ganged prime movers are modeled as a single unit using the same approach and set of inputs described in Sections 14.2 and 14.3. An example of ganging multiple generators into a packaged unit would be packaging of three $200-\mathrm{kW}$ microturbines to get a CHP system with $600 \mathrm{~kW}$ of rated power output.

As an example, Figure 8 shows the fuel consumption and electrical efficiency of one $200-\mathrm{kW}$ microturbine $^{17}$ and Figure 9 shows the fuel burn rate and electrical efficiency curves for three of the units shown in Figure 8 if operated together to provide $600 \mathrm{~kW}$ of power.

${ }^{17}$ Capstone Turbine Corporation, Capstone C1000 Series Microturbine Systems Technical Reference (November 2011), publication 410072 Rev B. 


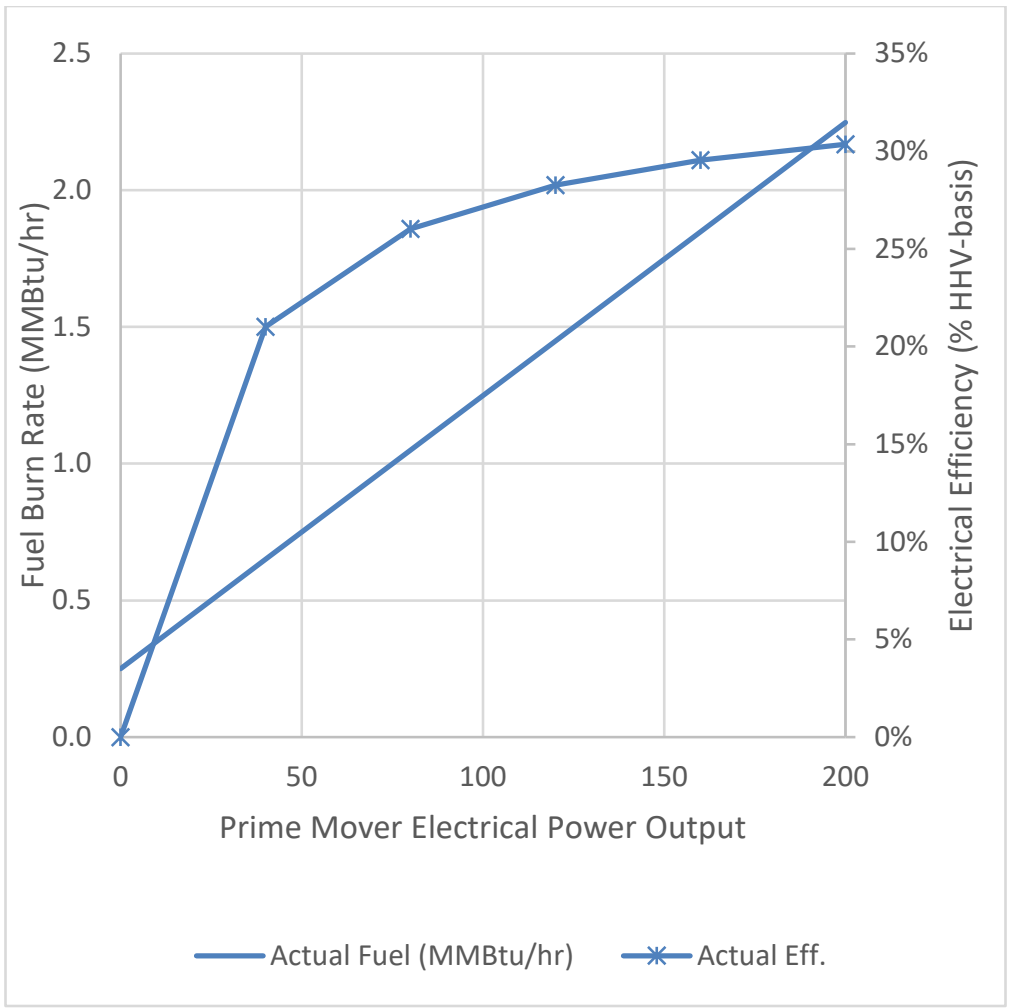

Figure 8. Fuel consumption and electrical efficiency versus load for one 200-kW microturbine

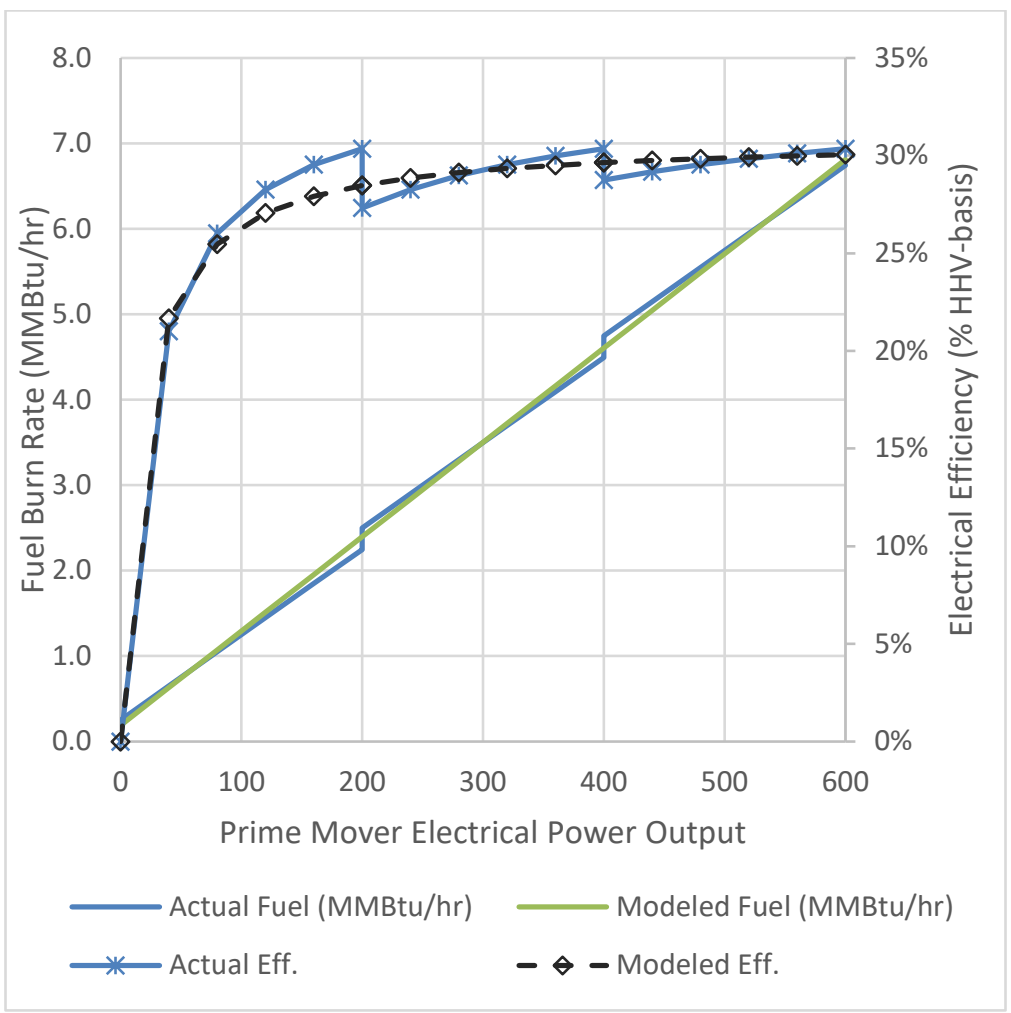

Figure 9. Actual and REopt-modeled fuel and electrical efficiency curves for three 200-kW generators packaged as one unit 
In Figure 9 the discontinuous efficiency curve and fuel burn rate curve are the actual expected performance values. Each discontinuity shows how the fuel consumption changes as each 200$\mathrm{kW}$ microturbine is turned on. In REopt Lite, we simplify this behavior to allow the ganged packaged units to be modeled as one prime mover rather than, in this case, three separate generators. The continuous efficiency and fuel burn rates in Figure 9 show the simplification. In this example, the simplification introduces some error on fuel burn rates from $-7 \%$ to $+4 \%$ over the ganged unit's power output range. The available heat recovery parameters are similarly approximated.

\subsection{Combustion Turbine Supplementary Duct Firing}

It is common in combustion turbine CHP applications to add supplementary firing capability to the heat recovery steam generator. The ability to model supplementary firing in REopt Lite will be added in a later release.

\subsection{CHP Auxiliary and Parasitic Loads}

Parasitic and auxiliary loads include power required to run the CHP fuel pump/compressor, feedwater pumps, waste heat rejection fans, etc. For the default CHP units included in REopt Lite, these loads are captured in the CHP net rated power output and fuel efficiency parameters. For user-entered CHP systems, the user is advised account for these auxiliary loads in the performance metrics entered.

\subsection{CHP Operations Constraints}

As a best practice to avoid increased O\&M requirements, there are low load regimes that prime movers should not be operated within for extended periods of time. For this reason, REopt Lite includes a user-adjustable constraint called Minimum Electric Loading of Prime Mover. The value is entered as fraction of nameplate rated power. Minimum electric load fractions for default parameters by prime mover type are described in Section 14.8, Default CHP Cost and Performance Parameters by Prime Mover Type and Size Class.

As a user option, CHP generated power can export to the grid in the model. ${ }^{18}$

\subsection{Default CHP Cost and Performance Parameters by Prime Mover Type and Size Class}

Default CHP performance and cost parameters are provided within the model for a number of prime movers and size classes (size ranges) for each prime mover. Default costs and performance values assume one prime mover per CHP system. Default costs and performance parameters are shown in Table 14 through Table 16, one table for each prime mover type. The numbers in these tables are in the range of expected cost and performance based on the DOE CHP Fact Sheets (DOE Advanced Manufacturing Office 2017). The raw data used to calculate the average values for each size class are given in Appendix A. All default values are based on natural gas and are provided at near ISO rated conditions.

\footnotetext{
${ }^{18}$ In a scenario where there is no financial value for exported power, REopt Lite may still export power to the grid in some time periods to avoid the CHP minimum loading constraint to generate and make use of the heat.
} 


\section{Note: Default costs and performance for natural gas CHP are not modified for other user-selected fuels. It is incumbent upon the user to review and modify costs and performance as warranted.}

The values in the tables for electrical and thermal efficiency, and the expected input for userspecified values, are based on fuel HHV.

Note: The default values in the user interface set the electric efficiency and heating efficiency at $50 \%$ to $100 \%$ load values described in this section. The result is that the prime movers are modeled as constant efficiency units over their operating load range. This greatly simplifies the complexity of the optimization model and therefore reduces model runtimes. The user can adjust the $100 \%$ and $50 \%$ load efficiency values to model prime movers as variable efficiency units but should expect longer solve times and some runs that may time out before a solution is found. If modeling a variable efficiency prime mover, the user is encouraged to fix the size of the generator of interest by setting the maximum size equal to the minimum size.

The total installed costs for CHP are entered as per-unit electric power capacity. The user can enter a single power-specific cost $(\$ / \mathrm{kW})$ or enter two costs $(\$ / \mathrm{kW})$ to generate a linear cost function. If a single input is entered, the model uses the same total installed cost $(\$ / \mathrm{kW})$ for all CHP sizes. If both input fields are entered, total installed costs will be calculated by linear interpolation between the two cost limits. For linear interpolation, costs must be entered in ascending order (from left to right) and the total installed cost input must also have both input fields entered. CHP sizes less than the smaller size will have the first cost $(\$ / \mathrm{kW})$, and CHP sizes larger than the larger size will have the second cost $(\$ / \mathrm{kW})$. This linear interpolation of costs is not available for the other technology options.

In the user interface, the user first selects the existing boiler thermal production type (which the CHP system will also supply) - either hot water or steam. Then the user inputs their electric and heating loads. Built-in logic uses the thermal production type and the average annual heating load to determine the default CHP prime mover type - either reciprocating engine or combustion turbine - and the size class of that prime mover. Table 13 gives the threshold of average boiler fuel load over which the default prime mover switches from reciprocating engine to combustion turbine for hot water and steam. The reasoning for this logic is that reciprocating engines are more cost effective at smaller scales and similarly efficient at producing hot water compared to combustion turbines. Combustion turbines become applicable at larger scales and are more efficient at producing steam.

Table 13. Threshold of Average Boiler Fuel Load over which the Default Prime Mover Switches from Reciprocating Engine to Combustion Turbine

\begin{tabular}{|l|c|c|}
\hline & $\begin{array}{c}\text { Hot Water (Assumes Boiler } \\
\text { Efficiency of 0.8) }\end{array}$ & $\begin{array}{c}\text { Steam (Assumes Boiler } \\
\text { Efficiency of 0.75) }\end{array}$ \\
\hline $\begin{array}{l}\text { Threshold of average boiler fuel } \\
\text { load over which the default } \\
\text { prime mover switches from } \\
\text { reciprocating engine to } \\
\text { combustion turbine }\end{array}$ & $\begin{array}{c}27.0 \mathrm{MMBtu} / \mathrm{hr} \text { (equates to } \\
\text { roughly } 5,100 \mathrm{~kW} \text { reciprocating } \\
\text { engine and } 3,600 \mathrm{~kW} \\
\text { combustion turbine) }\end{array}$ & $\begin{array}{c}7.0 \mathrm{MMBtu} / \mathrm{hr} \text { (equates to } \\
\text { roughly } 3,700 \mathrm{~kW} \text { reciprocating } \\
\text { engine and } 1,000 \mathrm{~kW} \\
\text { combustion turbine) }\end{array}$ \\
\hline
\end{tabular}


The user has the option override this default prime mover logic by clicking the "Change default prime mover \& size class?" checkbox. In this case, the user has full control of the prime mover, and they must also select the size class that they want to consider.

It is the user's option to constrain the search space for CHP size. For the example above, the user could enter the 'Minimum non-zero power capacity (kW)' as $100 \mathrm{~kW}$ and the 'Maximum electric power capacity (kW)' as $600 \mathrm{~kW}$. In this case, REopt Lite would run the optimization with default costs and performance representative of this range and the model would return a size within this $100-$ to- $600-\mathrm{kW}$ range, if cost effective, or a $0-\mathrm{kW}$ size if CHP in this size range is not cost effective. Alternatively, the user could select to model a CHP system with costs and performance for a generator in the range of 100 to $600 \mathrm{~kW}$ but can expand the search space of the model to allow it to consider system sizes that are either above or below this range to see if cost-optimal sizing might indicate sizes outside the selected range might be cost effective. In REopt Lite, the defaults for the minimum and maximum sizes for the search space are greater than the size class size ranges as shown in the tables.

As seen in Table 14 through Table 16, the default minimum size is $0 \mathrm{~kW}$ for all prime movers and size classes, meaning "no CHP" is always a possible result based on the optimization to minimize life cycle cost. The default 'Minimum non-zero power capacity (kW)' is $50 \%$ of the lower bound of the size class; however, if the result is a CHP size less than the lower bound of the size class, it is advised to rerun the model with the next-lowest size class. The default 'Maximum electric power capacity (kW)' is set to a high value for all size classes, although it is also advised to increase the size class appropriately if the result is higher than the upper bound of the chosen size class.

The user can enter a single power-specific cost $(\$ / \mathrm{kW})$ or enter two costs $(\$ / \mathrm{kW})$ to generate a linear cost function. If a single input is entered, the model uses the same total installed cost $(\$ / \mathrm{kW})$ for all CHP sizes. If two size-cost pairs are entered, total installed costs are calculated by linear interpolation between the two cost limits. Default costs are provided for two size-cost pairs as shown in Table 14 through Table 16. When two size-cost pairs are entered, CHP sizes less than the smaller size will have the first cost pair $(\$ / \mathrm{kW})$ and sizes larger than the larger cost pair will have the second cost $(\$ / \mathrm{kW})$.

Default heat recovery parameters assume the following process heat load conditions:

- Hot water is generated $\left(160^{\circ} \mathrm{F}\right.$ inlet and $180^{\circ} \mathrm{F}$ outlet, consistent with default heat loop conditions described in Section 5.2, Heating Plant) for reciprocating engines and microturbines.

- Steam is generated (150 psig saturated) for a combustion turbine prime mover.

Note: It is possible that the user could set up a model that is internally inconsistent/illogical. For example, a user could specify that the existing heating plant generates steam and selects a prime mover type that is appropriate only for hot water systems. The model might still run in this case but solution results would be invalid. 
Table 14. Reciprocating Engine Cost and Performance Parameters Included in REopt Lite

\begin{tabular}{|c|c|c|c|c|c|c|}
\hline Size Class & Class 0 & Class 1 & Class 2 & Class 3 & Class 4 & Class 5 \\
\hline Class size low $(\mathrm{kW})$ & 30 & 30 & 100 & 630 & 1,140 & 3,300 \\
\hline Class size high $(\mathrm{kW})$ & 9,300 & 100 & 630 & 1,140 & 3,300 & 10,000 \\
\hline $\begin{array}{l}\text { Minimum electric power } \\
\text { capacity }(\mathrm{kW})\end{array}$ & 0 & 0 & 0 & 0 & 0 & 0 \\
\hline $\begin{array}{l}\text { Minimum non-zero power } \\
\text { capacity (kW) }\end{array}$ & 15 & 15 & 50 & 315 & 570 & 1,650 \\
\hline $\begin{array}{l}\text { Maximum electric power } \\
\text { capacity }(\mathrm{kW})\end{array}$ & 10,000 & 10,000 & 10,000 & 10,000 & 10,000 & 10,000 \\
\hline $\begin{array}{l}\text { Installed cost function, installed } \\
\text { cost }(\$ / \mathrm{kW}) \text {, and size pair at } \\
\text { lower size }\end{array}$ & $\begin{array}{l}\$ 3,300 \\
30 \mathrm{~kW}\end{array}$ & $\begin{array}{r}\$ 3,300 \\
30 \mathrm{~kW}\end{array}$ & $\begin{array}{l}\$ 2,900 \\
100 \mathrm{~kW}\end{array}$ & $\begin{array}{l}\$ 2,700 \\
630 \mathrm{~kW}\end{array}$ & $\begin{array}{c}\$ 2,370 \\
1,140 \\
\mathrm{~kW}\end{array}$ & $\begin{array}{c}\$ 1,800 \\
3,300 \mathrm{~kW}\end{array}$ \\
\hline $\begin{array}{l}\text { Installed cost function, installed } \\
\text { cost }(\$ / \mathrm{kW}) \text {, and size pair at } \\
\text { larger size }\end{array}$ & $\begin{array}{c}\$ 1,430 \\
9,300 \\
\mathrm{~kW}\end{array}$ & $\begin{array}{l}\$ 2,900 \\
100 \mathrm{~kW}\end{array}$ & $\begin{array}{l}\$ 2,700 \\
630 \mathrm{~kW}\end{array}$ & $\begin{array}{l}\$ 2,370 \\
1,140 \\
\mathrm{~kW}\end{array}$ & $\begin{array}{l}\$ 1,800 \\
3,300 \\
\mathrm{~kW}\end{array}$ & $\begin{array}{c}\$ 1,430 \\
9,300 \mathrm{~kW}\end{array}$ \\
\hline Fixed O\&M (\$/kW/yr) & 0 & 0 & 0 & 0 & 0 & 0 \\
\hline Variable O\&M cost $(\$ / \mathrm{kWh})$ & 0.019 & 0.0245 & 0.0225 & 0.020 & 0.0175 & 0.0125 \\
\hline $\begin{array}{l}\text { Electric efficiency at } 100 \% \text { load } \\
\text { (HHV basis) }\end{array}$ & $35.6 \%$ & $29.6 \%$ & $32.1 \%$ & $35.8 \%$ & $39.0 \%$ & $41.5 \%$ \\
\hline $\begin{array}{l}\text { Hot water thermal efficiency at } \\
100 \% \text { load (HHV basis) }\end{array}$ & $43.6 \%$ & $50.3 \%$ & $47.9 \%$ & $43.6 \%$ & $40.5 \%$ & $36.8 \%$ \\
\hline $\begin{array}{l}\text { Steam thermal efficiency at } \\
100 \% \text { load (HHV basis) }\end{array}$ & $14.8 \%$ & $0.0 \%$ & $18.2 \%$ & $16.9 \%$ & $14.4 \%$ & $12.8 \%$ \\
\hline $\begin{array}{l}\text { Cooling thermal factor (single } \\
\text { effect) }\end{array}$ & 0.83 & 0.80 & 0.83 & 0.85 & 0.85 & 0.85 \\
\hline $\begin{array}{l}\text { Min. electric loading of prime } \\
\text { mover ( } \% \text { of rated electric } \\
\text { capacity) }\end{array}$ & $50 \%$ & $50 \%$ & $50 \%$ & $50 \%$ & $50 \%$ & $50 \%$ \\
\hline
\end{tabular}


Table 15. Micro-Turbine Cost and Performance Parameters Included in REopt Lite

\begin{tabular}{|c|c|c|c|c|c|}
\hline Size Class & Class 0 & Class 1 & Class 2 & Class 3 & Class 4 \\
\hline Class size low (kW) & 30 & 30 & 60 & 190 & 950 \\
\hline Class size high $(\mathrm{kW})$ & 1,290 & 60 & 190 & 950 & 1,290 \\
\hline $\begin{array}{l}\text { Minimum electric power capacity } \\
(\mathrm{kW})\end{array}$ & 0 & 0 & 0 & 0 & 0 \\
\hline $\begin{array}{l}\text { Minimum non-zero power } \\
\text { capacity (kW) }\end{array}$ & 21 & 21 & 42 & 133 & 665 \\
\hline $\begin{array}{l}\text { Maximum electric power } \\
\text { capacity }(\mathrm{kW})\end{array}$ & 1,000 & 1,000 & 1,000 & 1,000 & 1,290 \\
\hline $\begin{array}{l}\text { Installed cost function, installed } \\
\text { cost }(\$ / \mathrm{kW}) \text {, and size pair at } \\
\text { lower size }\end{array}$ & $\begin{array}{l}\$ 3,600 \\
30 \mathrm{~kW}\end{array}$ & $\begin{array}{l}\$ 3,600 \\
30 \mathrm{~kW}\end{array}$ & $\begin{array}{l}\$ 3,220 \\
60 \mathrm{~kW}\end{array}$ & $\begin{array}{l}\$ 3,150 \\
190 \mathrm{~kW}\end{array}$ & $\begin{array}{c}\$ 2,500 \\
1,000 \\
\mathrm{~kW}\end{array}$ \\
\hline $\begin{array}{l}\text { Installed cost function, installed } \\
\text { cost }(\$ / \mathrm{kW}) \text {, and size pair at } \\
\text { larger size }\end{array}$ & $\begin{array}{l}\$ 2,400 \\
1,290 \mathrm{~kW}\end{array}$ & $\begin{array}{l}\$ 3,220 \\
60 \mathrm{~kW}\end{array}$ & $\begin{array}{l}\$ 3,150 \\
190 \mathrm{~kW}\end{array}$ & $\begin{array}{l}\$ 2,500 \\
1,000 \mathrm{~kW}\end{array}$ & $\begin{array}{l}\$ 2,400 \\
1,290 \\
\mathrm{~kW}\end{array}$ \\
\hline Fixed O\&M (\$/kW/yr) & 0 & 0 & 0 & 0 & 0 \\
\hline $\begin{array}{l}\text { Variable O\&M cost }(\$ / \mathrm{hr} / \mathrm{kW}- \\
\text { rated) }\end{array}$ & 0.017 & 0.026 & 0.021 & 0.012 & 0.012 \\
\hline $\begin{array}{l}\text { Electric efficiency at } 100 \% \text { load } \\
\text { (HHV basis) }\end{array}$ & $27.1 \%$ & $24.0 \%$ & $26.3 \%$ & $28.5 \%$ & $28.8 \%$ \\
\hline $\begin{array}{l}\text { Hot water thermal efficiency at } \\
100 \% \text { load (HHV basis) }\end{array}$ & $41.2 \%$ & $47.3 \%$ & $42.7 \%$ & $38.2 \%$ & $37.6 \%$ \\
\hline $\begin{array}{l}\text { Steam thermal efficiency at } \\
100 \% \text { load (HHV basis) }\end{array}$ & $0.0 \%$ & $0.0 \%$ & $0.0 \%$ & $0.0 \%$ & $0.0 \%$ \\
\hline $\begin{array}{l}\text { Cooling thermal factor (single } \\
\text { effect) }\end{array}$ & 0.94 & 0.94 & 0.94 & 0.94 & 0.94 \\
\hline $\begin{array}{l}\text { Min. electric loading of prime } \\
\text { mover ( } \% \text { of rated electric } \\
\text { capacity) }\end{array}$ & $30 \%$ & $30 \%$ & $30 \%$ & $30 \%$ & $30 \%$ \\
\hline
\end{tabular}


Table 16. Combustion Turbine Cost and Performance Parameters Included in REopt Lite

\begin{tabular}{|c|c|c|c|c|c|c|c|}
\hline Size Class & Class 0 & Class 1 & Class 2 & Class 3 & Class 4 & Class 5 & $\begin{array}{c}\text { Class } \\
6\end{array}$ \\
\hline Class size low $(\mathrm{kW})$ & 950 & 950 & 1,800 & 3,300 & 5,400 & 7,500 & 14,000 \\
\hline Class size high $(\mathrm{kW})$ & 20,000 & 1,800 & 3,300 & 5,400 & 7,500 & 14,000 & 20,000 \\
\hline $\begin{array}{l}\text { Minimum electric power } \\
\text { capacity }(\mathrm{kW})\end{array}$ & 0 & 0 & 0 & 0 & 0 & 0 & 0 \\
\hline $\begin{array}{l}\text { Minimum non-zero power } \\
\text { capacity }(\mathrm{kW})\end{array}$ & 475 & 475 & 900 & 1,650 & 2,700 & 3,750 & 7,000 \\
\hline $\begin{array}{l}\text { Maximum electric power } \\
\text { capacity }(\mathrm{kW})\end{array}$ & 20,000 & 20,000 & 20,000 & 20,000 & 20,000 & 20,000 & 20,000 \\
\hline $\begin{array}{l}\text { Installed cost function, } \\
\text { installed cost }(\$ / \mathrm{kW}) \text {, and } \\
\text { size pair at lower size }\end{array}$ & $\begin{array}{l}\$ 4,480 \\
950 \mathrm{~kW}\end{array}$ & $\begin{array}{l}\$ 4,480 \\
950 \mathrm{~kW}\end{array}$ & $\begin{array}{c}\$ 3,900 \\
1,800 \\
\text { kW } \\
\end{array}$ & $\begin{array}{c}\$ 3,320 \\
3,300 \\
\text { kW } \\
\end{array}$ & $\begin{array}{c}\$ 2,550 \\
5,400 \\
\text { kW }\end{array}$ & $\begin{array}{l}\$ 2,017 \\
7,500 \mathrm{~kW}\end{array}$ & $\begin{array}{c}\$ 1,650, \\
14,000 \\
\mathrm{~kW}\end{array}$ \\
\hline $\begin{array}{l}\text { Installed cost function, } \\
\text { installed cost }(\$ / k W) \text {, and } \\
\text { size pair at larger size }\end{array}$ & $\begin{array}{l}\$ 1,474 \\
20,000 \\
\text { kW }\end{array}$ & $\begin{array}{c}\$ 3,900 \\
1,800 \\
\mathrm{~kW}\end{array}$ & $\begin{array}{c}\$ 3,300 \\
3,320 \\
\mathrm{~kW}\end{array}$ & $\begin{array}{c}\$ 2,550 \\
5,400 \\
\text { kW }\end{array}$ & $\begin{array}{c}\$ 2,017 \\
7,500 \\
\mathrm{~kW}\end{array}$ & $\begin{array}{c}\$ 1,650 \\
14,000 \\
\text { kW }\end{array}$ & $\begin{array}{l}\$ 1,474, \\
20,000 \\
\text { kW }\end{array}$ \\
\hline Fixed O\&M (\$/kW/yr) & 0 & 0 & 0 & 0 & 0 & 0 & 0 \\
\hline $\begin{array}{l}\text { Variable O\&M cost } \\
\text { (\$/hr/kW-rated) }\end{array}$ & 0.012 & 0.015 & 0.014 & 0.013 & 0.013 & 0.011 & 0.010 \\
\hline $\begin{array}{l}\text { Electric efficiency at } 100 \% \\
\text { load (HHV basis) }\end{array}$ & $26.7 \%$ & $21.8 \%$ & $23.1 \%$ & $25.4 \%$ & $28.1 \%$ & $29.6 \%$ & $31.5 \%$ \\
\hline $\begin{array}{l}\text { Hot water thermal efficiency } \\
\text { at } 100 \% \text { load (HHV basis) }\end{array}$ & $46.5 \%$ & $50.7 \%$ & $49.8 \%$ & $47.0 \%$ & $46.8 \%$ & $44.9 \%$ & $42.5 \%$ \\
\hline $\begin{array}{l}\text { Steam thermal efficiency at } \\
100 \% \text { load (HHV basis) }\end{array}$ & $42.2 \%$ & $46.2 \%$ & $45.1 \%$ & $42.5 \%$ & $42.6 \%$ & $40.8 \%$ & $38.5 \%$ \\
\hline $\begin{array}{l}\text { Cooling thermal factor } \\
\text { (double effect) }\end{array}$ & 0.90 & 0.90 & 0.90 & 0.90 & 0.90 & 0.90 & 0.90 \\
\hline $\begin{array}{l}\text { Min. electric loading of } \\
\text { prime mover ( } \% \text { of rated } \\
\text { electric capacity) }\end{array}$ & $50 \%$ & $50 \%$ & $50 \%$ & $50 \%$ & $50 \%$ & $50 \%$ & $50 \%$ \\
\hline
\end{tabular}

The parameter 'Cooling thermal factor' included in Table 14 through Table 16 is the

'Knockdown factor for CHP-supplied thermal to Absorption Chiller' input in the user interface.

See Section 15, Absorption Chilling for more information.

\subsection{CHP Scheduled and Unscheduled Maintenance}

Scheduled and unscheduled maintenance is required for CHP systems, and the REopt model accounts for this by using predetermined periods of time for which CHP is unavailable to produce electric and thermal power. Default maintenance periods are provided for reciprocating engine, microturbine, and combustion turbine prime movers based on operational data and consultation with industry experts. CHP suppliers give warranty or guarantees based on a minimum availability (hours available to operate divided by all 8,760 hours of the year); often this number is lower than the actual availability of the CHP system because the suppliers want to have some safety margin on their guarantees. The maintenance period defaults used in REopt represent estimates for the actual CHP availability. The schedule of the default periods and summary metrics can be viewed in the REopt web tool, but a high-level summary is given in Table 17. 
Table 17. Default Maintenance Periods and Unavailability Summary Metrics

\begin{tabular}{|l|c|c|c|}
\hline & $\begin{array}{c}\text { Recip. } \\
\text { Engine }\end{array}$ & $\begin{array}{c}\text { Combustion } \\
\text { Turbine }\end{array}$ & $\begin{array}{c}\text { Micro- } \\
\text { turbine }\end{array}$ \\
\hline Number of planned maintenance events & 6 & 2 & 2 \\
\hline Duration of planned (days) & 3 & 2 & 3 \\
\hline Number of unplanned maintenance events & 3 & 2 & 2 \\
\hline Duration of unplanned (days) & 2 & 2.5 & 2.5 \\
\hline Availability & $95 \%$ & $97 \%$ & $97 \%$ \\
\hline
\end{tabular}

The number of planned and unplanned outages are spread out throughout the year, and in the default schedules there is no more than one in any given month. Each period is assumed to be a consecutive block of time. The planned maintenance periods are assumed to be scheduled on the weekends (which is typically off-peak if there is a time-of-use characteristic to the electric rate tariff) to the extent possible (if 2 days or less in duration). The unplanned maintenance periods are assumed to occur during the weekdays to be conservative in that the electricity rates and loads are typically the highest during the weekdays.

The user may also upload their own custom maintenance schedule with the provided form. The form is available by clicking the "Download schedule" link under the CHP Maintenance Schedule section of the CHP accordion. Table 18 provides a description of the form headings and valid inputs for those attributes.

Table 18. Custom Uploaded CHP Maintenance Schedule Form Description

\begin{tabular}{|c|c|c|c|c|c|}
\hline & month & $\begin{array}{l}\text { start_week_- } \\
\text { of_month }\end{array}$ & $\begin{array}{c}\text { start_day_ } \\
\text { of_week } \\
\text { (1=Monday) }\end{array}$ & $\begin{array}{c}\text { start_hour (1- } \\
\text { 24) }\end{array}$ & duration_hours \\
\hline Description & $\begin{array}{l}\text { The month in } \\
\text { which the } \\
\text { outage starts }\end{array}$ & $\begin{array}{l}\text { The week of } \\
\text { the month in } \\
\text { which the } \\
\text { outage starts }\end{array}$ & $\begin{array}{c}\text { The day of the } \\
\text { week in which } \\
\text { the outage } \\
\text { starts }\end{array}$ & $\begin{array}{l}\text { The hour of } \\
\text { the day in } \\
\text { which the } \\
\text { outage starts }\end{array}$ & $\begin{array}{c}\text { The duration of } \\
\text { the outage, in } \\
\text { hours }\end{array}$ \\
\hline Valid range & $1-12$ & $1-6$ & $1-7$ & $1-24$ & 8,760 \\
\hline Other notes & \multicolumn{5}{|c|}{$\begin{array}{l}\text { All values must be integers. The start_week_of_month=1 and } \\
\text { start_week_of_month=5 or } 6 \text { often do not contain all } 7 \text { days of the week; see Figure } \\
10 \text { for a grid of how the start_week_of_month and start_day_of_week align with an } \\
\text { example month (January } 2017 \text { ). Some months do not have a start_week_of_month=5 } \\
\text { or } 6 \text {. An outage must not extend past the end of the year; alternatively, specify two } \\
\text { separate outages, one for the end and one for the beginning of the year. }\end{array}$} \\
\hline
\end{tabular}




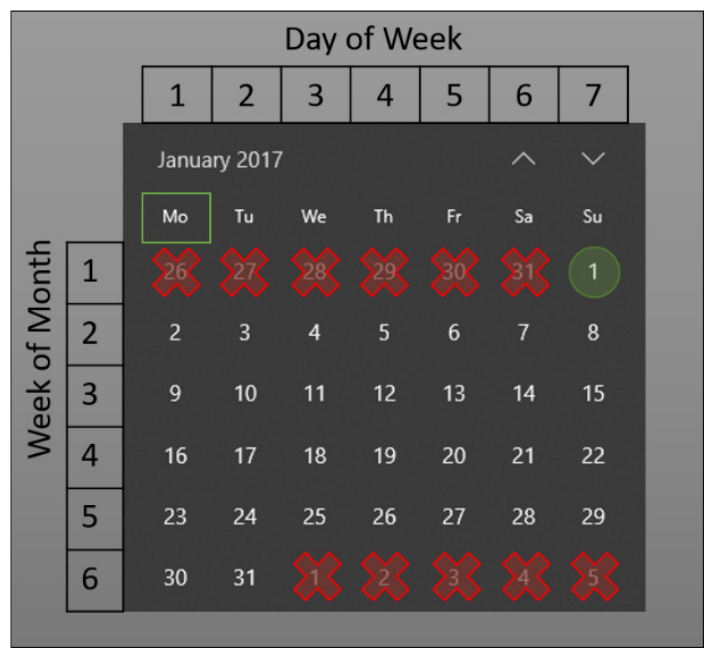

\section{Figure 10. Example month for understanding how to build a maintenance period with respect to the year/month calendar}

In the example month and year of Figure 10 (January 2017), the start_week_of_month=1 only has Sunday (start_day_of_week=6) in it, so the first valid Monday of the month would be specified by start_week_of_month=2 and start_day_of_week=1. Regarding an outage specified at the end of the month, start_week_of_month $=6$ only has Monday and Tuesday in it, so an entry of start_week_of_month $=6$ and start_day_of_week $=3$ (Wednesday) would be invalid. Note too that valid numbers for start_hour are 1 to 24 and that 1 represents the first hour of the day, midnight to 1 a.m. So, if the user wants to model a maintenance starting at 7 a.m., the value entered as start_hour would be 6 .

REopt Lite identifies the total system size that minimizes the life cycle cost of energy at the site. The minimum non-zero electric power capacity is used to narrow the lower limit of size range of the search space that REopt Lite can select. For example, if the user enters a 'Minimum electric power capacity (kW)' of 0 and a 'Maximum electric power capacity (kW)' of 100, REopt Lite could return a value anywhere between 0 and $100 \mathrm{~kW}$. With this 'Minimum non-zero power capacity (kW)' input, the user could enter a value of $30 \mathrm{~kW}$, for example, so that REopt Lite can only return a system size of 0 or a size between $30 \mathrm{~kW}$ and $100 \mathrm{~kW}$.

\section{Absorption Chilling}

Absorption chillers generate chilled water using a heat source to drive a refrigeration cycle. If an absorption chiller is considered, it is assumed there is an existing chilled water loop served by existing electrically driven chillers and the condenser water loop has sufficient capacity to dissipate the increased load required by the absorption chiller. REopt Lite does not size or cost the cooling distribution system, the existing electrically driven chiller, nor size or cost incremental capacity requirements for absorption chiller condenser heat rejection.

The user can elect to consider adding an absorption chiller to supplement cooling provided by the existing electricity driven chiller plant. The heat required for the absorption chiller can be provided from CHP, the existing heating plant, and hot water TES if it is included in the model solution. The model assumes the optional absorption chiller would be connected to the process 
heating loop, i.e., it would add heating load to the user-entered heat load. A direct-fired absorption chiller cannot be modeled.

Absorption chiller unit heat requirements are not adjusted based on chiller loading or other operational conditions. The COP value is assumed to represent the average absorption chiller performance throughout the year. The user can adjust the default COP value. The default absorption chiller COP is dependent on whether the user selects the existing facility's boiler as producing steam or hot water. If the user selects steam, the absorption chiller is assumed to be a two stage-type unit driven by steam with a COP of $1.42 \mathrm{~kW}$ thermal cooling output per $\mathrm{kW}$ thermal heat input. For a hot water boiler, we assume the absorption chiller is driven by hot water and therefore a single stage with a COP of 0.74 (DOE Advanced Manufacturing Office 2017).

The parameter 'Cooling thermal factor' included in Table 14 through Table 16 in Section 14.8, Default CHP Cost and Performance Parameters by Prime Mover Type and Size Class, is a 'knockdown' factor that is used to estimate the impact of absorption chillers' higher-quality heat requirements on the recoverable heat from CHP. It is the 'Knockdown factor for CHP-supplied thermal to Absorption Chiller' input in the user interface. The cooling thermal factor effectively reduces the absorption chiller COP based on two considerations: (1) the hot water-driven single effect absorption chiller requires slightly higher-temperature water than the assumed hot water loop temperatures used to estimate the default heat recovery parameters; and (2) the absorption chiller's return water temperature is not as low as the building's hot water loop return water temperature (see Section 7.4, Heating Loads). Both factors reduce the amount of CHP-produced thermal power that can be applied to the absorption chiller with its nominal COP value. For a combustion turbine prime mover supplying steam to a two-stage absorption chiller, a cooling thermal factor is also applied for a similar reason.

In addition to heat, the absorption chiller consumes electricity for heat rejection to cooling towers. The electric-based COP default is $14.1 \mathrm{kWt} / \mathrm{kWe}$, which is equivalent to $0.25 \mathrm{kWe} / \mathrm{ton}$. This is also a user input and can be changed.

The model does not include turn-down limits (minimum unloading ratio constraint) on the absorption chiller.

If the user selects to screen for an absorption chiller, the default cost assumption is that there is room for the absorption chiller within the existing cooling plant and that integration for parallel operation with the existing electric chillers can be accomplished. Additional costs for constructing a new building or extensive retrofits are not included. The user can change the default costs to include these.

The following default capital and O\&M costs for a steam-driven two-stage absorption chiller (when the prime mover is a combustion turbine) are applied in the model as a function of the facility cooling load entered by the user (DOE Advanced Manufacturing Office 2017):

1. If the peak cooling load is $\leq 330$ tons,

a. the default CAPEX is $\$ 3,300 /$ ton 
b. the default fixed O\&M is $\$ 21.00 /$ ton/year.

2. If the peak cooling load is $>1,000$ tons,

a. the default CAPEX is $\$ 2,000 /$ ton

b. the default fixed O\&M is $\$ 7.00 /$ ton/year.

3. If the peak cooling load is $>330$ tons and $\leq 1,000$ tons, the default CAPEX and fixed O\&M cost is found by linear interpolation of the costs in 1 and 2 .

The following default costs for a hot water-driven single-stage absorption chiller (when the prime mover is a reciprocating engine, microturbine, or a fuel cell) are applied in the model as a function of the facility cooling load entered by the user:

1. If the peak cooling load is $\leq 50$ tons,

a. the default CAPEX is $\$ 6,000 /$ ton

b. the default fixed O\&M is $\$ 42.00 /$ ton/year.

2. If the peak cooling load is 440 tons,

a. the default CAPEX is $\$ 2,250 /$ ton

b. the default fixed O\&M is $\$ 14.00 /$ ton/year.

3. If the peak cooling load is $\geq 1,320$ tons,

a. the default CAPX is $\$ 2,000 /$ ton

b. the default fixed O\&M is $\$ 7.00 /$ ton/year.

4. If the peak cooling load is $>50$ tons and $\leq 440$ tons, the default costs are found by linear interpolation of the costs in 1 and 2.

5. If the peak cooling load is $>440$ tons and $<1,320$ tons, the default costs are found by linear interpolation of the costs between 2 and 3 .

\section{Thermal Energy Storage}

Hot water and chilled water storage tanks are insulated tanks used to store thermal energy to decouple production from consumption. We assume TES can be added to the existing systems without replacing hot water boilers or chillers. If significant system upgrades are required to add TES, the user should adjust the TES capital costs to reflect those.

The TES tank is assumed to be stratified with a thermocline that separates the supply water (hot water in hot water TES or chilled water in a chilled water TES) from the return water. 
Tank capacity and costs are entered in units of gallons and \$/gallon respectively. Volumetric units are converted to thermal capacity units within the model based on the assumed hot water loop temperatures and chilled water loop temperatures.

Hot water from the boiler plant or the CHP heat recovery unit can be stored in a hot water TES. This hot water can then be applied to the facility hot water load or to an absorption chiller load, if considered.

Chilled water generated from the existing electric chiller and possible supplementary absorption chiller can be stored in the chilled water TES tank.

The model determines the size of TES based on the cost-optimal maximum volume of stored energy. We assume the TES can be fully charged with either hot water or chilled water. However, a minimum stored energy requirement is imposed as a fraction of total TES tank volume. This is used to represent the thermocline region which must be maintained at low stored energy levels to separate the warmer and colder sides of the thermocline. The default minimum energy storage value is $10 \%$ for both the hot and chilled water TES. The minimum SOC default is estimated from Figure 2 in ASHRAE (2016). Any minimum SOC constraint applies all year and therefore the implicit assumption is that if a tank is selected by the model, it is thermally maintained all year.

In the first hour of the simulation, stored energy is assumed to be $50 \%$ of the TES capacity. Between the maximum and minimum stored energy limits, the capacity of stored hot/chilled water is a function of the water volume stored in the tank's supply side of the thermocline.

The heat loss (or gain) depends on many factors, including the temperature of the stored fluid (and therefore the SOC of the tank), surface area to volume of the tank (which varies with TES capacity and diameter-to-height ratio), thickness of tank insulation, and ambient conditions (temperature, solar insolation, and wind speed) (ASHRAE 2016). For REopt Lite, thermal loss is modeled as a constant rate and comes from general rules of thumb in the cited references and heat transfer calculations. The default value is $0.04 \%$ per hour (approximately $1 \%$ per day). It is intended to capture heat loss (or gain in the case of chilled water TES) of the tank to and from the environment. This time-dependent lost energy has to be met by the chiller by producing more chilled water for chilled water TES and by the boiler by producing more hot water for hot water TES when TES is included in the solution.

The maximum discharge rate from TES is not constrained as we assume in application it would be determined by the facility cooling or heating loads and therefore in the model we allow the load in any hour to be completely served by stored chilled water or hot water if the TES has sufficient stored energy.

The maximum charge rates for hot water and chilled water TES are described in the two sections that immediately follow.

Default capital costs are taken from Glazer (2019), which provides estimated total installed costs for chilled water TES over a range of sizes. Costs from the reference in units of $\$ /$ ton-hour are converted to $\$ /$ gallon assuming a $14^{\circ} \mathrm{F}$ temperature difference. The average costs range from 
$\$ 2.82 /$ gallon for 100,000 -gallon tank to $\$ 0.93 /$ gallon for a 2,000,000-gallon system. These costs from the reference, converted as described, are shown in Figure 11.

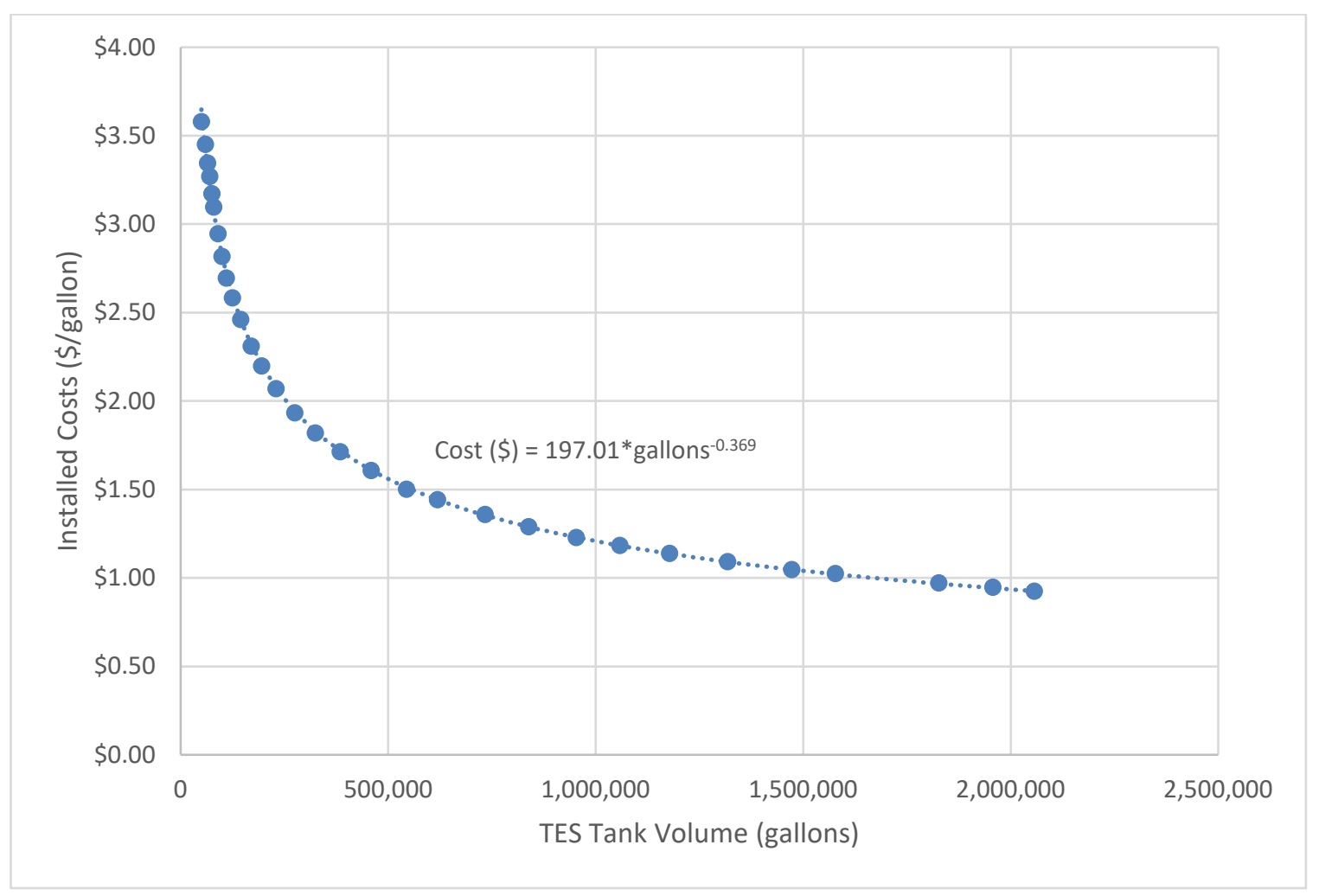

Figure 11. TES installed cost estimates from Glazer (2019) and applying a $14^{\circ} \mathrm{F}$ temperature differential assumption

In REopt Lite, we set the default value to $\$ 1.50 /$ gallon which is the cost in the reference for a tank of about 550,000 gallons. We assume hot water and chilled water TES tanks cost the same on a per-gallon basis.

O\&M for the chilled water storage tank is assumed to be a fixed yearly cost, so there is no variable O\&M cost component. The default cost is $\$ 0 /$ gallon/year but the user may add this for more detailed cost assessment.

\subsection{Chilled Water TES}

If included, the storage system is assumed to be a single stratified water tank. The thermal storage capacity per gallon of chilled water storage is a function of the supply and return temperatures of the chilled water process loop. These are described in Section 5.3, Cooling Plant.

As described in Section 5.3, there is an assumed upper limit on the cooling capacity of the cooling plant to impose a reasonable upper limit on the maximum charging rate of chilled water TES. Therefore, the maximum charge rate is determined by the assumed size of the cooling plant. 


\subsection{Hot Water TES}

Hot water TES can support economics of CHP by allowing time shifting of CHP's thermal resource in situations where the electricity demand and thermal demands are not time coincident. Hot water TES is an option only for hot water process loads. If the user selects steam as the 'Existing boiler type,' the hot water TES option is disabled.

If included, the storage system is assumed to be a single stratified water tank. The thermal storage capacity per gallon of hot water storage is a function of the supply and return temperatures of the hot water process loop. These are described in Section 5.2, Heating Plant. There is no constraint on discharge rate.

As described in Section 5.2, there is an assumed upper limit on the heating capacity of the hot water heating plant to impose a reasonable upper limit on the maximum charging rate of hot water TES. Therefore, the maximum charge rate is determined by the assumed size of the heating plant.

\section{Outputs}

\subsection{Cases}

REopt Lite reports results for up to three cases: Business-as-Usual, Financial, and Resilience. Resilience is reported only if the user selects a resilience analysis.

- Business-as-Usual: In this case, the site purchases energy solely from the utility. In a scenario modeling a grid outage where the critical load can be fully met by an existing generator for some period of time, then Business-As-Usual also includes the costs of using that existing generation capacity for that time.

- Financial: The case that minimizes the present value of all future energy costs over the analysis period. This case may include a combination of utility, PV, wind, CHP, chilled water storage, hot water storage, absorption chiller, and/or battery. This case is not optimized for a grid outage.

- Resilience: This case is optimized to sustain a critical load in the event of a grid outage while minimizing the present value of all future energy costs over the analysis period. This case may include a combination of utility, PV, wind, battery, CHP, chilled water storage, hot water storage, absorption chiller, and/or backup generator.

\subsection{System Size}

REopt Lite leverages a mathematical optimization model to determine the cost-optimal size and dispatch of DER including PV, wind, CHP, backup diesel generator, absorption chiller, battery, and thermal storage subject to technology costs, the site's load, cost of electricity and fuel, solar or wind resource, and other financial inputs.

A technology is typically recommended if it reduces the life cycle cost of energy for the site. In general, DER is often cost effective at sites that have a higher utility rate, higher utility escalation rate, lower DER cost, good incentives, and/or good renewable resource that make energy generated by DER less expensive than energy purchased from the utility. For CHP, the 
combination of high electric rate, low fuel cost, and high thermal load can make electricity generated by CHP less expensive than electricity purchased from the utility and heat generated by CHP less expensive than heat produced by the existing boiler. For batteries, high demand charges are important for economic viability. Thermal storage is often cost effective at sites where thermal energy is produced at a different time than it is needed. An absorption chiller may be cost effective at sites that have a high cooling load, high electricity costs, low fuel costs, and/or CHP.

If DER is not recommended, this is likely because utility costs, incentives, and/or renewable resources are low, and therefore DER may not be cost competitive with utility prices at this time. The cheapest option might be to continue to purchase grid electricity. On the other hand, if the model over-sizes a technology, resulting in energy curtailed or sent back to the grid at no value, this is likely because the value it gains from energy generated at other times reduces total life cycle cost of energy, even if energy is curtailed in certain hours.

If the user specified a minimum DER size or a resiliency requirement, DER may be recommended to meet these requirements even if it does not reduce the life cycle cost of energy. If the user did not select a technology for inclusion in the analysis, or set the maximum technology size to zero, the technology will not be recommended even if it is cost effective. The total system size includes an existing system if one has been specified in the inputs (for PV and diesel generator).

The model considers a continuous range of technology sizes; it is not limited to the discrete sizes available in the marketplace. Therefore, the system sizes recommended may not be commercially available. In this case, the user may identify available sizes close to the optimal recommendation and rerun the model with fixed sizes equal to the commercially available size.

\subsubsection{Energy Production}

In addition to system size, REopt Lite also reports AC energy generation from each technology, and fuel used to generate this energy (where applicable). The expected annual energy production from the PV system is the average expected production over the system lifetime (including degradation), not Year 1 production.

\subsection{Dispatch Strategy}

The model optimizes the dispatch strategy of each technology to meet the load at minimum life cycle cost of energy. In each time step, generation may serve the load, or be stored, curtailed, or, in the case of electricity, exported back to the grid. Storage technologies may be charged or discharged. The dispatch strategies for electric, heating, and cooling loads are provided in interactive graphs that allow the user to scroll through the year, zoom in on select days, and zoom out to see the full year. The full hourly dispatch strategy for one year can be downloaded as a .csv file.

\subsubsection{Electric Dispatch}

For every hour of the year, the electric dispatch chart titled System Performance Year One shows the electric load as a black line. For evaluations that include chilled water TES or an absorption chiller, a dashed black line represents the business-as-usual electric load, which was entered by 
the user. The total electric load, shown as the solid black line, is the net of this business-as-usual load and any cooling electric offsets or additions due to recommended absorption chiller and/or chilled water TES systems. This net total electric load is the load that must be met by some combination of technologies in every hour of the year.

The load must be met in each hour by either energy purchased from the grid, PV, wind, battery storage, CHP, or, in an outage, by an optional backup diesel generator. PV and wind generate energy according to when the resource is available and either serve the load, charge the battery, or export to the grid. CHP generates energy according to site economics and either serves the load, charges the battery, or exports to the grid. Load not met by PV and/or wind is met either by the CHP prime mover, the battery discharging, the grid, or, in an outage, by an optional backup diesel generator. During a grid outage, excess generated electricity is curtailed.

The optimization model decides whether to charge, discharge, or do nothing with the battery in each hour. If it charges or discharges, it also decides by how much. The battery SOC is shown as a dotted black line. The battery is sized and dispatched to minimize the life cycle cost of energy at the site. There is no demand target. Instead, demand levels are determined by the optimization model.

\subsubsection{Heating Thermal Dispatch}

A similar chart is provided for the heating thermal dispatch. The business-as-usual heating load is shown as a dotted black line. This heating load represents the typical heating boiler fuel load entered by the user. It does not include the hot water TES or absorption chiller loads which are included in the total heating load, shown with a solid black line.

The load must be met in each hour by either the existing boiler, CHP, or hot water TES serving the load. The CHP generates heat and the hot water TES stores and releases heat according to site economics. Both CHP and hot water TES either serve the load, charge the TES, or supply heat to an absorption chiller. The hot water TES state of charge in each hour is represented by a dotted red line.

Like the battery, the optimization model decides whether to charge, discharge, or do nothing with the hot TES in each hour. If it charges or discharges, it also decides by how much. The TES is sized and dispatched to minimize the life cycle cost of energy at the site.

\subsubsection{Cooling Thermal Dispatch}

Finally, a third chart is provided for the cooling thermal dispatch. For every hour of the year, the chart shows the total cooling load as a solid black line. This load must be met in each hour by either the electric chiller, the absorption chiller, or the chilled water TES. The absorption chiller and electric chiller either meet the load or charge the chilled water TES according to site economics. The chilled water TES state of charge in each hour is represented by a dotted red line.

The optimization model decides whether to charge, discharge, or do nothing with the chilled water TES in each hour. If it charges or discharges, it also decides by how much. The TES is sized and dispatched to minimize the life cycle cost of energy at the site. There is no demand target; demand levels are determined by the optimization model. 


\subsection{Economics}

REopt Lite reports economic metrics on the financial viability of each case. Metrics reported include Year 1 utility costs before tax, life cycle utility costs after tax, capital cost before and after incentives, Year 1 and life cycle O\&M costs, total life cycle cost, NPV, payback period, internal rate of return, and life cycle cost of energy. For third party-financed systems, annual payments from the host to the third-party owner are also reported. More detailed financials are available in the downloadable pro forma spreadsheet.

The objective of the optimization is to minimize life cycle cost (and therefore maximize NPV). The life cycle cost is the present value of costs, after taxes and incentives associated with each case. For the Business-as-Usual Case, this includes only the utility demand and energy costs, existing boiler fuel costs, and future O\&M costs for any existing PV and/or generator. In a scenario where a critical load is fully met by an existing backup diesel generator, then this calculation also includes the fuel and operating cost of using that existing generation capacity to meet the outage. For the Financial or Resilience cases, this includes the utility demand and energy costs as well as the capital expenditure, tax benefits and incentives, and O\&M costs associated with the project, including PV, wind, energy storage, CHP, absorption chiller, and total backup diesel generator (if recommended). Note that fixed fees charged by the utility are not included, and therefore the actual life cycle cost of energy may be higher if the utility charges fixed fees. However, because fixed fees cannot be offset by PV, wind, energy storage, or CHP, these net out in the calculation of NPV.

The NPV is the present value of the savings (or costs if negative) realized by the project. This is calculated as the difference between the Business-As-Usual Case life cycle energy cost and the Resilience Case or Financial Case life cycle energy cost. For financial analysis, NPV will be greater than or equal to zero, unless the user has forced a minimum technology size. For a resilience analysis, the NPV may be positive or negative. A negative NPV indicates the project is not economically viable, or in other words, the site will pay more than their base case cost of electricity. Note that avoided outage costs are not considered in the NPV calculation; adding in these avoided costs may increase NPV.

While REopt Lite reports payback period and IRR as well, the optimization does not maximize these metrics. REopt Lite is maximizing NPV, and IRR and payback period are simply calculated for the system that maximizes NPV.

\subsection{Resilience}

If the user selects a resilience evaluation, REopt Lite optimizes the system to meet the typical load at minimum life cycle cost, with the additional constraint that the load must be met without the grid during the specified outage period. The results then compare the system optimized for resilience to one optimized for financial benefit.

\subsubsection{Outage Simulation}

The outage simulator provides an evaluation of the amount of time a system can survive grid outages throughout the year. In the user interface, it is accessible on the results page after the optimization is run by selecting the 'Simulate outages' button. 
The system was optimized to meet a specific outage period, but because load and solar and wind resource vary throughout the year, a system sized to sustain a given outage duration at one time may not be able to sustain the same outage duration occurring at a different time. Outages are simulated starting at every hour of the year (8,760 simulation runs) and the amount of time the system can sustain the critical load during each outage is calculated. Based on the simulation, REopt Lite reports the minimum, average, and maximum time survived across the 8,760 simulated outages, as well as avoided outage costs. Data can be viewed for the entire year, or by month or hour in which the outage starts.

The battery SOC at the start of each outage is determined by the economically optimal dispatch strategy. This means that if the battery was being used for peak shaving prior to the outage, it may be at a low SOC when the outage occurs.

Note that in order to gain this resiliency, the PV/wind/CHP/battery/generator must be installed as a system capable of electrically islanding. This incurs additional costs above a typical gridconnected system that are not included in the economics presented here. Additional components required may include a manual or automatic transfer switch, critical load panel, and additional controls capabilities in the inverter for islanded operation.

\subsubsection{Effect of Resilience Costs and Benefits}

If the user runs the outage simulator, REopt Lite provides an interactive chart that allows the user to consider the cumulative effect of extra costs and benefits of increased resilience on the project's NPV. Upgrading the recommended system to a microgrid allows a site to operate in both grid-connected and island mode. This incurs additional costs above a typical grid-connected system, which are not included in the economics of the primary optimization. This "microgrid upgrade cost" may include extra equipment such as controllers, distribution system infrastructure, and communications upgrades required to make the DERs an island-able system.

Economic benefit is also observed when the value of avoiding the costs of an outage is considered. Avoided outage costs are the losses that the site would experience if the load were not met. The value of lost load is used to determine the avoided outage costs by multiplying value of lost load in $\$ / \mathrm{kWh}$ by the average number of hours that the critical load can be met by the energy system (determined by simulating outages occurring at every hour of the year), and multiplying by the mean critical load. The Interruption Cost Estimate Calculator ${ }^{19}$ can aid in estimating interruption costs and/or the benefits associated with reliability improvements.

These microgrid upgrade costs and avoided outage costs are not factored into the optimization results, but their impact can be evaluated in this chart. The sliders under the chart allow the user to change the Microgrid Upgrade Cost and the Avoided Outage Costs to analyze the impact on the NPV after Microgrid Costs and Benefits, while the NPV Before Microgrid Investment, which is determined by the optimization results, remains static.

\subsection{Emissions}

REopt Lite reports Year 1 emissions attributable to electricity purchased from the utility (including electricity lost in transmission and distribution) and on-site fuels consumed by the

${ }^{19}$ https://icecalculator.com/home 
existing boiler, CHP, and/or backup diesel generator for each case evaluated. Percent reduction in $\mathrm{CO} 2$ emissions is also reported, calculated as the difference between the Business-as-Usual Case total emissions and the Resilience Case total emissions or the Financial Case total emissions, divided by the business-as-usual total emissions.

\subsection{Caution}

Investment decisions should not be made on REopt Lite results alone. These results assume perfect prediction of solar irradiance, wind speed, and electrical and thermal loads. In practice, actual savings may be lower based on the ability to accurately predict solar irradiance, wind speed, and load, and the control strategies used in the system. When modeling a grid outage, the results assume perfect foresight of the impending outage, allowing the battery system to charge in the hours leading up the outage. If a natural gas-fueled CHP system is included, the resiliency results assume the natural gas supply is not disrupted during an electrical grid outage.

The results include both expected energy and demand savings. However, the hourly model does not capture intra-hour variability of the PV and wind resource. Because demand is typically determined based on the maximum 15-minute peak, the estimated savings from demand reduction may be exaggerated. The hourly simulation uses one year of load data and one year of solar and wind resource data. Actual demand charges and savings will vary from year to year as load and resource vary.

Asset dispatch decisions are determined by the model as part of the cost-minimization objective. In application, some aspects of these operational decisions may not work well with the existing infrastructure or may not follow best practices. For example, in results with CHP, boiler dispatch may result in short cycling or periodic boiler use that is not possible without hot-standby. The user should review the dispatch results with these limitations in mind.

REopt Lite may find CHP is cost effective but upon review of its operation, the user may find REopt Lite operated CHP in an unconventional manner. For example, CHP systems are often operated in baseload and sized to maximize heat recovery. In REopt Lite, CHP sizing and dispatch are determined as part of the cost-minimization objective. In some modeled scenarios, the determining value of CHP may be reduction of electric utility demand charges. The value of heat recovery and avoided utility electricity costs in off-peak hours may be insufficient to offset the operation costs of CHP and therefore REopt Lite might not operate CHP in baseload. Examination of the results may reveal the CHP system operated at low capacity factors or that the size of the unit resulted in low utilization of the available waste heat. The user is advised to review the relevant metrics and resultant economics to identify why the model has indicated CHP might be cost effective. For low capacity factors and/or low heat utilization, the value of the CHP unit might be heavily tilted to the power generated.

PV system performance predictions calculated by PVWatts include many inherent assumptions and uncertainties and do not reflect variations between PV technologies nor site-specific characteristics except as represented by inputs. For example, PV modules with better performance are not differentiated within PVWatts from lesser-performing modules.

Wind performance predictions are approximate only. Actual wind turbine performance is greatly affected by obstacles surrounding the turbine, including trees, buildings, silos, fences, or any 
other objects that could block the wind flow. Looking at a wind rose for the site is the best way to estimate the impact of local terrain and obstacles on the potential turbine energy production; Figure 12 gives a rule of thumb for where not to install a wind turbine (wind from the left).

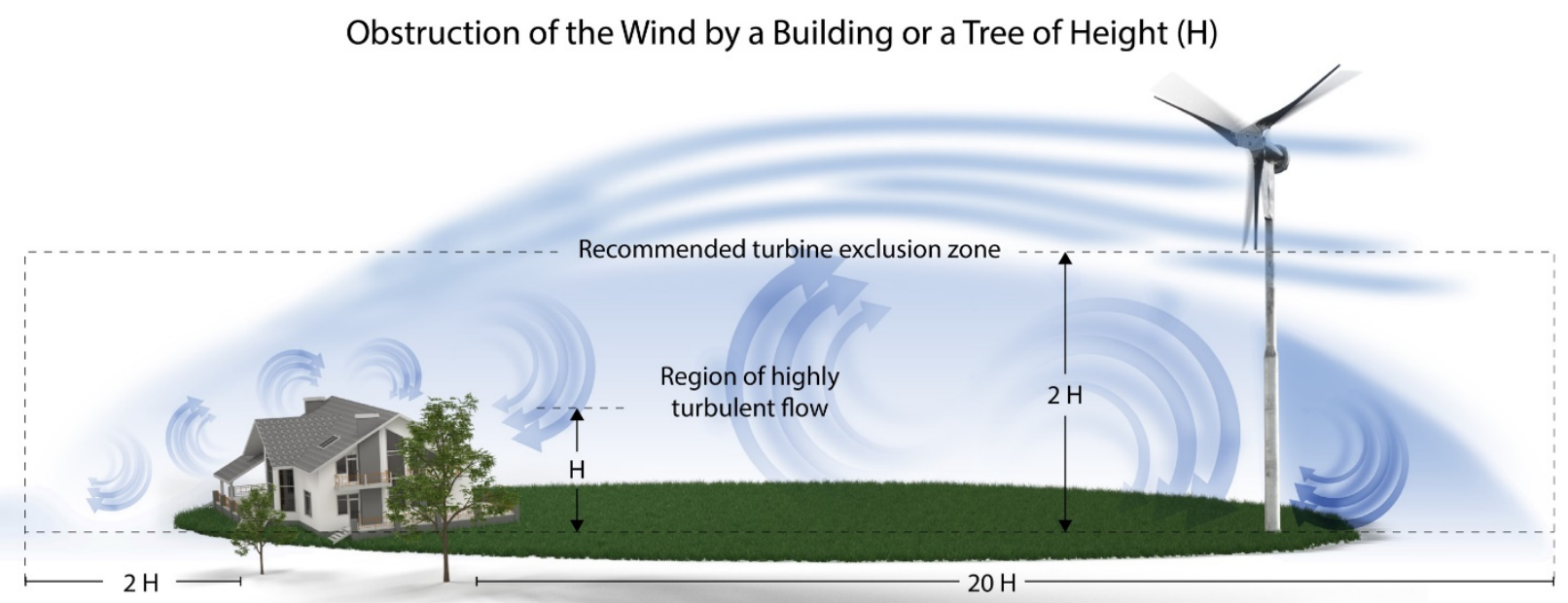

Figure 12. Obstacles to potential wind energy production

\subsection{Next Steps}

This model provides an estimate of the techno-economic feasibility of solar, wind, CHP, and battery, but investment decisions should not be made based on these results alone. Before moving ahead with project development, verify:

- The utility rate tariff is correct

- Note that a site may have the option or may be required to switch to a different utility rate tariff when installing a PV, wind, CHP, or battery system

○ Contact your utility for more information

- Actual load data is used rather than a simulated load profile

- PV, wind, CHP, and battery costs and incentives are accurate for your location

- There may be additional value streams not included in this analysis such as ancillary services or capacity payments

- Financial inputs are accurate, especially discount rate and utility escalation rate

- Other factors that can inform decision-making, but are not captured in this model, are considered. These may include:
○ roof integrity
- shading considerations
- obstacles to wind flow
$\circ$ ease of permitting 

○ mission compatibility
○ regulatory and zoning ordinances
$\bigcirc$ utility interconnection rules
- availability of funding

- Multiple systems integrators are consulted and multiple proposals are received. These will help to refine system architecture and projected costs and benefits. REopt Lite results can be used to inform these discussions.

\section{REopt Lite Default Values, Typical Ranges, and Sources}

Table 19. Site and Utility Inputs, Default Values, Ranges, and Sources

\begin{tabular}{|l|l|l|l|}
\hline Input & $\begin{array}{l}\text { Default } \\
\text { Value }\end{array}$ & Range & Source \\
\hline $\begin{array}{l}\text { CHP Standby } \\
\text { charge based } \\
\text { on CHP size } \\
\text { (\$/kW/month) }\end{array}$ & 0 & $0-30$ & $\begin{array}{l}\text { Standby Rates for Customer-sited Resources; Issues, } \\
\text { Considerations, and the Elements of Model Tariffs; } \\
2009 . \\
\text { https://www.epa.gov/sites/production/files/2015- }\end{array}$ \\
\hline $\begin{array}{l}\text { 10/documents/standby rates.pdf } \\
\text { Standby Rates for Combined Heat and Power } \\
\text { Systems; Economic Analysis and Recommendations } \\
\text { for Five States; 2014. } \\
\text { https://www.raponline.org/knowledge-center/standby- }\end{array}$ \\
$\begin{array}{l}\text { rates-for-combined-heat-and-power-systems-economic- } \\
\text { analysis-and-recommendations-for-five-states/ }\end{array}$ \\
\hline $\begin{array}{l}\text { Existing boiler } \\
\text { HHV-basis) }\end{array}$ & $80 \%$ & $50-95 \%$ & $\begin{array}{l}\text { U.S. DOE Commercial Reference Buildings } \\
\text { https://www.energy.gov/eere/buildings/commercial- }\end{array}$ \\
\hline $\begin{array}{l}\text { Max. boiler } \\
\text { thermal } \\
\text { capacity as a } \\
\text { factor of peak } \\
\text { heating load }\end{array}$ & 1.25 & $\underline{\text { reference-buildings }}$ \\
\hline
\end{tabular}


Table 20. Load Profile Inputs, Default Values, Ranges, and Sources

\begin{tabular}{|l|l|l|l|}
\hline Input & $\begin{array}{l}\text { Default } \\
\text { Value }\end{array}$ & Range & Source \\
\hline $\begin{array}{l}\text { Electric } \\
\text { cooling plant } \\
\text { coefficient of } \\
\text { performance } \\
\text { (COP) } \\
\text { (kWt/kWe) }\end{array}$ & 3.5 & $2-7$ & U.S. DOE Commercial Reference Buildings \\
\hline $\begin{array}{l}\text { Max. chiller } \\
\text { thermal } \\
\text { capacity as a } \\
\text { factor of peak } \\
\text { cooling load }\end{array}$ & 1.25 & $\underline{\text { https://www.energy.gov/eere/buildings/commercial- }}$ \\
\hline
\end{tabular}

Table 21. Financial Inputs, Default Values, Ranges, and Sources

\begin{tabular}{|c|c|c|c|}
\hline Input & $\begin{array}{l}\text { Default } \\
\text { Value }\end{array}$ & Range & Source \\
\hline $\begin{array}{l}\text { Analysis } \\
\text { period (years) }\end{array}$ & 25 & $10-40$ & $\begin{array}{l}2020 \text { Annual Technology Baseline and Standard } \\
\text { Scenarios. NREL, 2020. } \\
\text { https://atb.nrel.gov/ } \\
\text { Defaults for Economic lifetime of distributed commercial } \\
\text { renewable technologies used for NREL analyses vary. The } \\
2020 \text { Annual Technology Baseline includes options for } 20 \\
\text { or } 30 \text { years. Typical internal REopt analyses use } 25 \text { years. } \\
\text { ASTM E917-17, Standard Practice for Measuring Life- } \\
\text { Cycle Costs of Buildings and Building Systems, ASTM } \\
\text { International, West Conshohocken, PA, 2017. } \\
\text { www.astm.org } \\
\text { This ASTM standard uses a 25-year study period for most } \\
\text { examples. } \\
\text { NREL's System Advisory Model (SAM) uses a 25-year } \\
\text { analysis period default. January 2021. } \\
\text { https://sam.nrel.gov } \\
\text { Energy Independence and Security Act of 2007, Sec. } \\
441 . \text { Public Law 110-140, 110th US Congress. } \\
\text { https://www.gpo.gov/fdsys/pkg/PLAW- } \\
\text { 110publ140/pdf/PLAW-110publ140.pdf } \\
\text { Public building lifecycle costs are evaluated over a 40-year } \\
\text { period in federal analyses. }\end{array}$ \\
\hline $\begin{array}{l}\text { Host discount } \\
\text { rate, nominal } \\
(\%)\end{array}$ & $8.3 \%$ & $2 \%-15 \%$ & $\begin{array}{l}2020 \text { Annual Technology Baseline and Standard } \\
\text { Scenarios. NREL, } 2020 . \\
\text { https://atb.nrel.gov/ }\end{array}$ \\
\hline
\end{tabular}




\begin{tabular}{|c|c|c|c|}
\hline Input & $\begin{array}{l}\text { Default } \\
\text { Value }\end{array}$ & Range & Source \\
\hline & & & $\begin{array}{l}\text { The NREL } 2020 \text { Annual Technology Baseline projects a } \\
2020 \text { nominal weighted average cost of capital (WACC) of } \\
5.64 \% \text { as a mid-maturity nominal discount rate for Market } \\
\text { Factors Financial assumptions to evaluate distributed PV } \\
\text { and } 7.12 \% \text { for land-based wind. The projections for } 2021 \\
\text { are } 5.64 \% \text { for PV and } 6.75 \% \text { for wind. Discount rate varies } \\
\text { significantly between distributed PV and wind adopters. } \\
\text { NREL's System Advisory Model (SAM) uses a default } \\
\text { nominal discount rate of } 9.06 \% \text {, but warns the user to } \\
\text { carefully consider using a custom rate. } \\
\text { https://sam.nrel.gov } \\
\text { Energy Price Indices and Discount Factors for Life- } \\
\text { Cycle Cost Analysis - } 2020 \text { Annual Supplement to NIST } \\
\text { Handbook } 135 . \text { DOE, April } 2020 \text {. } \\
\text { https://nvlpubs.nist.gov/nistpubs/ir/2020/NIST.IR.85-3273- } \\
\text { 35.pdf } \\
\text { Federal projects use a nominal discount rate of } 2.5 \% \text {. }\end{array}$ \\
\hline $\begin{array}{l}\text { Host effective } \\
\text { tax rate }(\%)\end{array}$ & $\begin{array}{l}26 \% \\
21 \%+5 \\
\%\end{array}$ & $\begin{array}{l}15 \%- \\
21 \% \text { for } \\
\text { federal } \\
\text { corporate } \\
\text { income } \\
\text { taxes plus } \\
0 \%-12 \% \\
\text { state } \\
\text { corporate } \\
\text { income } \\
\text { taxes }\end{array}$ & $\begin{array}{l}2020 \text { Annual Technology Baseline and Standard } \\
\text { Scenarios. NREL, } 2020 . \\
\text { https://atb.nrel.gov/ } \\
\text { Tax rate (federal and state) used for NREL analyses. } \\
2019 \text { Instructions for Form 1120: U.S. Corporation } \\
\text { Income Tax Return. U.S. Department of the Treasury, } \\
\text { Internal Revenue Service, January } 2021 . \\
\text { https://www.irs.gov/pub/irs-pdf/i1120.pdf } \\
\text { Federal corporate income tax rate of a flat } 21 \% \text { is listed } \\
\text { under Schedule J, Tax Computation and Payment on page } \\
\text { 18. } \\
\text { State Corporate Income Tax Rates and Brackets for } \\
2020 . \text { Tax Foundation, February } 2020 . \\
\text { https://files.taxfoundation.org/20200212140256/State- } \\
\text { Corporate-Income-Tax-Rates-and-Brackets-for-20201.pdf } \\
\text { State corporate income tax rates and brackets listed for } \\
2020 . \\
\text { Local income and state and local property taxes should } \\
\text { also be taken into account. }\end{array}$ \\
\hline $\begin{array}{l}\text { Electricity } \\
\text { cost } \\
\text { escalation } \\
\text { rate, nominal } \\
(\%)\end{array}$ & $2.3 \%$ & $\begin{array}{l}1.4 \%- \\
2.9 \%\end{array}$ & $\begin{array}{l}\text { The nominal electricity cost escalation rate is provided } \\
\text { explicitly in the U.S. Energy Information Administration's } \\
\text { (EIA) Annual Energy Outlook and can also be calculated } \\
\text { implicitly by combining the NIST Handbook's real } \\
\text { electricity cost escalation rates with expected inflation } \\
\text { rates. }\end{array}$ \\
\hline
\end{tabular}




\begin{tabular}{|c|c|c|c|}
\hline Input & $\begin{array}{l}\text { Default } \\
\text { Value }\end{array}$ & Range & Source \\
\hline & & & $\begin{array}{l}\text { Annual Energy Outlook } 2020 \text { - Electricity Supply, } \\
\text { Disposition, Prices, and Emissions. EIA, January } 2020 \text {. } \\
\text { https://www.eia.gov/outlooks/aeo/data/browser/\#/?id=3- } \\
\text { AEO2020\&cases=ref2020\&sourcekey=0 } \\
\text { The EIA predicts a } 2.1 \% \text { average nominal annual } \\
\text { commercial electricity escalation rate from } 2020-2045 \text { in } \\
\text { their reference case scenario. Regional variation yields a } \\
\text { range of annual electricity cost escalation rates from } 1.4 \% \\
\text { to } 2.9 \% \text {. }\end{array}$ \\
\hline $\begin{array}{l}\text { Existing boiler } \\
\text { fuel cost } \\
\text { escalation } \\
\text { rate, nominal } \\
(\%)\end{array}$ & $3.4 \%$ & $\begin{array}{l}3.3 \%- \\
3.5 \%\end{array}$ & $\begin{array}{l}\text { The nominal natural gas cost escalation rate is provided } \\
\text { explicitly in the EIA's Annual Energy Outlook. } \\
\text { Annual Energy Outlook } 2019 \text { - Energy Prices by } \\
\text { Sector and Source. EIA, January } 2019 \text {. } \\
\text { https://www.eia.gov/outlooks/aeo/data/browser/\#/?id=3- } \\
\text { AEO2019\&region=1- } \\
\text { 0\&cases=ref2019\&start=2020\&end=2045\&f=A\&linechart=r } \\
\text { ef2019-d111618a.5-3-AEO2019.1-0\&map=ref2019- } \\
\text { d111618a.4-3-AEO2019.1- } \\
\text { \&ctype=linechart\&sourcekey=0 } \\
\text { The EIA predicts a 3.3\% and 3.5\% average nominal } \\
\text { annual commercial and industrial natural gas escalation } \\
\text { rate from 2020-2045, respectively in their reference case } \\
\text { scenario, assuming an inflation rate of } 1.9 \% \text {. }\end{array}$ \\
\hline $\begin{array}{l}\text { CHP fuel cost } \\
\text { escalation } \\
\text { rate, nominal } \\
(\%)\end{array}$ & $3.4 \%$ & $\begin{array}{l}3.3 \%- \\
3.5 \%\end{array}$ & $\begin{array}{l}\text { The nominal natural gas cost escalation rate is provided } \\
\text { explicitly in the EIA's Annual Energy Outlook. } \\
\text { Annual Energy Outlook } 2019 \text { - Energy Prices by } \\
\text { Sector and Source. EIA, January } 2019 \text {. } \\
\text { https://www.eia.gov/outlooks/aeo/data/browser/\#/?id=3- } \\
\text { AEO2019\&region=1- } \\
\text { 0\&cases=ref2019\&start=2020\&end=2045\&f=A\&linechart=r } \\
\text { ef2019-d111618a.5-3-AEO2019.1-0\&map=ref2019- } \\
\text { d111618a.4-3-AEO2019.1- } \\
\text { \&\&ctype=linechart\&sourcekey=0 } \\
\text { The EIA predicts a 3.3\% and 3.5\% average nominal } \\
\text { annual commercial and industrial natural gas escalation } \\
\text { rate from 2020-2045, respectively in their reference case } \\
\text { scenario, assuming an inflation rate of } 1.9 \% \text {. }\end{array}$ \\
\hline $\begin{array}{l}\text { O\&M cost } \\
\text { escalation } \\
\text { rate }(\%)\end{array}$ & $2.5 \%$ & $\begin{array}{l}-0.2 \%- \\
4 \% .\end{array}$ & $\begin{array}{l}\text { O\&M costs are assumed to escalate at inflation rate. } \\
2020 \text { Annual Technology Baseline and Standard } \\
\text { Scenarios. NREL, 2020. } \\
\text { https://atb.nrel.gov/ } \\
\text { NREL analyses assume an inflation rate of } 2.5 \% \text {. }\end{array}$ \\
\hline
\end{tabular}




\begin{tabular}{|c|c|c|c|}
\hline Input & $\begin{array}{l}\text { Default } \\
\text { Value }\end{array}$ & Range & Source \\
\hline & & & $\begin{array}{l}\text { Energy Price Indices and Discount Factors for Life- } \\
\text { Cycle Cost Analysis - } 2020 \text { Annual Supplement to } \\
\text { NIST Handbook 135. DOE, April 2020. } \\
\text { https://nvlpubs.nist.gov/nistpubs/ir/2020/NIST.IR.85-3273- } \\
\text { 35.pdf } \\
\text { Federal projects use an inflation rate of }-0.5 \% \text {. } \\
\text { Historical Inflation Rates: } 1914-2020 . \text { U.S. Inflation } \\
\text { Calculator, January } 2021 . \\
\text { http://www.usinflationcalculator.com/inflation/historical- } \\
\text { inflation-rates/ } \\
\text { Lists monthly U.S. inflation rates from } 1914-2020 \text {. Inflation } \\
\text { rate in December } 2020 \text { listed as } 1.4 \% \text {. Since } 2010 \text {, } \\
\text { inflation rates have ranged from }-0.2 \% \text { to } 3.9 \% \text {. }\end{array}$ \\
\hline
\end{tabular}

Table 22. Emissions Inputs, Default Values, Ranges, and Sources

\begin{tabular}{|c|c|c|c|c|}
\hline Input & $\begin{array}{l}\text { Default } \\
\text { Value }\end{array}$ & Range & \multicolumn{2}{|l|}{ Source } \\
\hline $\begin{array}{l}\text { CO2 } \\
\text { emissions } \\
\text { factor for } \\
\text { utility-sourced } \\
\text { electricity } \\
\text { (lb/kWh) }\end{array}$ & $\begin{array}{l}\text { hourly } \\
\text { or } \\
\text { annual }\end{array}$ & $0.1-2.0$ & \multicolumn{2}{|c|}{$\begin{array}{l}\text { Hourly value used from AVERT tool: AVERT, } 2019 . \\
\text { "AVoided Emissions and geneRation Tool (AVERT) } \\
\text { User Manual”. Version 2.3. May 2019. } \\
\text { https://www.epa.gov/statelocalenergy/avoided-emissions- } \\
\text { and-generation-tool-avert. } \\
\text { For Hawaii and Alaska, eGRID value used: eGRID, } 2016 . \\
\text { “Emissions \& Generation Resource Integrated } \\
\text { Database (eGRID)". Last modified version is } \\
\text { 'egrid2016_data.xIsx' spreadsheet from 2016. } \\
\text { https://www.epa.gov/energy/emissions-generation- } \\
\text { resource-integrated-database-egrid. }\end{array}$} \\
\hline $\begin{array}{l}\text { Boiler natural } \\
\text { gas emissions } \\
\text { factor } \\
\text { (lb/MMBtu) }\end{array}$ & 116.9 & $100-140$ & \multicolumn{2}{|c|}{$\begin{array}{l}\text { EPA, 2015. "Fuel and Carbon Dioxide Emissions } \\
\text { Savings Calculation Methodology for Combined Heat } \\
\text { and Power Systems". U.S. Environmental Protection } \\
\text { Agency Combined Heat and Power Partnership. Feb. } \\
\text { 2015. } \\
\text { https://www.epa.gov/chp/fuel-and-carbon-dioxide- } \\
\text { emissions-savings-calculation-methodology-combined- } \\
\text { heat-and-power }\end{array}$} \\
\hline \multirow{6}{*}{$\begin{array}{l}\text { CHP natural } \\
\text { gas emissions } \\
\text { factor } \\
\text { (lb/MMBtu) }\end{array}$} & \multirow[t]{6}{*}{116.9} & \multirow[t]{6}{*}{$100-140$} & \multicolumn{2}{|c|}{$\begin{array}{l}\text { Value depends on the type of fuel for CHP. The default } \\
\text { assumes natural gas is the fuel. }\end{array}$} \\
\hline & & & Fuel Type & $\begin{array}{l}\text { CO2 Emissions Factor, } \\
\text { lb/MMBtu }\end{array}$ \\
\hline & & & Natural Gas ${ }^{1}$ & 116.9 \\
\hline & & & $\begin{array}{l}\text { Landfill gas, other } \\
\text { biomass gasses }{ }^{2}\end{array}$ & 0.0 \\
\hline & & & Propane $^{2}$ & 138.6 \\
\hline & & & \multicolumn{2}{|c|}{$\begin{array}{l}\text { 1.EPA, 2015. "Fuel and Carbon Dioxide Emissions } \\
\text { Savings Calculation Methodology for Combined } \\
\text { Heat and Power Systems". U.S. Environmental }\end{array}$} \\
\hline
\end{tabular}




\begin{tabular}{|c|c|c|c|}
\hline Input & $\begin{array}{l}\text { Default } \\
\text { Value }\end{array}$ & Range & Source \\
\hline & & & $\begin{array}{l}\text { Protection Agency Combined Heat and Power } \\
\text { Partnership. Feb. 2015. } \\
\text { https://www.epa.gov/chp/fuel-and-carbon-dioxide- } \\
\text { emissions-savings-calculation-methodology- } \\
\text { 2. } \\
\text { Combined-heat-and-power } \\
\text { Gas Inven. "Emission Factors for Greenhouse } \\
\text { https://www.epa.gov/sites/production/files/2018- } \\
\text { 03/documents/emission-factors mar 2018 0.pdf }\end{array}$ \\
\hline
\end{tabular}

Table 23. PV Inputs, Default Values, Ranges, and Sources

\begin{tabular}{|c|c|c|c|}
\hline Input & $\begin{array}{l}\text { Default } \\
\text { Value }\end{array}$ & Range & Source \\
\hline $\begin{array}{l}\text { System } \\
\text { capital cost } \\
(\$ / k W)\end{array}$ & $\$ 1600$ & $\begin{array}{l}\$ 1400- \\
\$ 1830\end{array}$ & $\begin{array}{l}2020 \text { Annual Technology Baseline and Standard } \\
\text { Scenarios. NREL, 2020. } \\
\text { https://atb.nrel.gov/ } \\
\text { NREL analyses assume a moderate } 2021 \text { distributed } \\
\text { commercial PV CAPEX of } \$ 1,672 / k W . \\
\text { Q4 2019/Q1 } 2020 \text { Solar Industry Update. NREL, May } \\
\text { 28, 2020. } \\
\text { https://www.nrel.gov/docs/fy20osti/77010.pdf } \\
\text { Preliminary Q1 } 2020 \text { data indicated that median prices } \\
\text { remained relatively flat with the exception of systems } \\
\text { above } 500 \text { kW, which dipped to } \$ 1400 / k W . \\
\text { U.S. Solar Photovoltaic System Cost Benchmark: Q1 } \\
\text { 2018. NREL, November 2018. } \\
\text { https://www.nrel.gov/docs/fy19osti/72399.pdf } \\
\text { The resource lists NREL's bottom-up cost calculations for } \\
\text { residential, commercial, and utility-scale PV. Commercial } \\
\text { PV is calculated to average } \$ 1.83 / W \text {. }\end{array}$ \\
\hline $\begin{array}{l}\text { O\&M cost } \\
\text { (\$/kW/year) }\end{array}$ & $\$ 16$ & $\$ 12-\$ 13$ & $\begin{array}{l}2020 \text { Annual Technology Baseline and Standard } \\
\text { Scenarios. NREL, } 2020 . \\
\text { https://atb.nrel.gov/ } \\
\text { Fixed O\&M expenses for distributed commercial PV in } \\
2021 \text { assumed for NREL analyses. }\end{array}$ \\
\hline Array azimuth & $\begin{array}{l}180^{\circ} \text { or } \\
0^{\circ}\end{array}$ & $0^{\circ}-360^{\circ}$ & $\begin{array}{l}\text { The default value of } 180^{\circ} \text { assumes the array is in the } \\
\text { northern hemisphere and is facing due south. When the } \\
\text { array is in the southern hemisphere, the assumption is that } \\
\text { it is facing due north and the array azimuth default value } \\
\text { changes to } 0^{\circ} \text {. } \\
\text { PVWatts Version } 5 \text { Manual. Dobos, Aron P., NREL, } \\
\text { September } 2014 \text {. } \\
\text { https://www.nrel.gov/docs/fy14osti/62641.pdf } \\
\text { Current PVWatts Online Help Manual. January } 2021 . \\
\text { https://pvwatts.nrel.gov/index.php }\end{array}$ \\
\hline
\end{tabular}




\begin{tabular}{|c|c|c|c|}
\hline Input & $\begin{array}{l}\text { Default } \\
\text { Value }\end{array}$ & Range & Source \\
\hline & & & $\begin{array}{l}\text { PVWatts uses a default azimuth of } 180^{\circ} \text { in the northern } \\
\text { hemisphere and } 0^{\circ} \text { in the southern hemisphere. } \\
\text { U.S. Solar Photovoltaic System Cost Benchmark: Q1 } \\
\text { 2018. NREL, November } 2018 \text {. } \\
\text { https://www.nrel.gov/docs/fy19osti/72399.pdf } \\
\text { The resource specifies an array azimuth of } 180^{\circ} \text {. }\end{array}$ \\
\hline $\begin{array}{l}\text { Array tilt - } \\
\text { Rooftop, } \\
\text { Fixed }\end{array}$ & $10^{\circ}$ & $0^{\circ}-60^{\circ}$ & $\begin{array}{l}\text { Rooftop PV is usually mounted at } 10-20 \text { degrees on a flat } \\
\text { roof to reduce wind loading and shading losses. PV on a } \\
\text { sloped roof is typically installed parallel to the roof's } \\
\text { surface, though azimuth and tilt angle can be adjusted if } \\
\text { desired. } \\
\text { Current PVWatts online Help Manual. January } 2021 . \\
\text { https://pvwatts.nrel.gov/index.php } \\
\text { For an array installed on a building's roof, you may want to } \\
\text { choose a tilt angle equal to the roof pitch. } \\
\text { U.S. Solar Photovoltaic System Cost Benchmark: Q1 } \\
\text { 2018. NREL, November } 2018 . \\
\text { https://www.nrel.gov/docs/fy19osti/72399.pdf } \\
\text { The resource specifies an array tilt of } 10^{\circ} \text {. } \\
\text { Best Practices for Operation and Maintenance of } \\
\text { Photovoltaic and Energy Storage Systems; 3rd } \\
\text { Edition. } 2018 \text {. } \\
\text { https://www.nrel.gov/docs/fy19osti/73822.pdf } \\
\text { For a ballasted system on a flat roof, a low tilt angle } \\
\text { (usually } 10^{\circ} \text { tilt) is required to reduce wind loads. }\end{array}$ \\
\hline $\begin{array}{l}\text { Array tilt - } \\
\text { Ground } \\
\text { mount, Fixed }\end{array}$ & $\begin{array}{l}\text { Tilt }= \\
\text { latitude }\end{array}$ & $0^{\circ}-90^{\circ}$ & $\begin{array}{l}\text { The default value assumes the tilt is equal to the latitude of } \\
\text { the site location. If the site is in the southern hemisphere, } \\
\text { this default is the absolute value of the latitude. } \\
\text { PVWatts Version } 5 \text { Manual. Dobos, Aron P., NREL, } \\
\text { September 2014. } \\
\text { https://www.nrel.gov/docs/fy14osti/62641.pdf } \\
\text { Current PVWatts Online Help Manual. January } 2021 . \\
\text { https://pvwatts.nrel.gov/index.php } \\
\text { PVWatts uses a default equal to the site latitude. } \\
\text { Advanced Photovoltaic Installations. Balfour, John, } \\
\text { Michael Shaw, and Nicole Bremer Nash. The Art and } \\
\text { Science of Photovoltaics. 2013. } \\
\text { https://books.google.com/books?id=t5uTktdsu3AC\&pg=PA } \\
77 \& \text { Ipg=PA77\&dq=pv+geometry+flat+roof\&source=bl\&ots } \\
\text { E4v99ljXqq\&sig=spZ0uf0Zdh- } \\
\text { zrK66Zldm6UN6ECs\&hl=en\&sa=X\&ved=0ahUKEwiErOjBI } \\
\text { evVAhUKw4MKHTzoCMMQ6AElcDAM\#v=onepage\&q=pv } \\
\text { \%20geometry\%20flat\%20roof\&f=false } \\
\text { Page 71 describes how in order to maximize annual yield, } \\
\text { the array should be tilted at the site's latitude. Decreasing }\end{array}$ \\
\hline
\end{tabular}




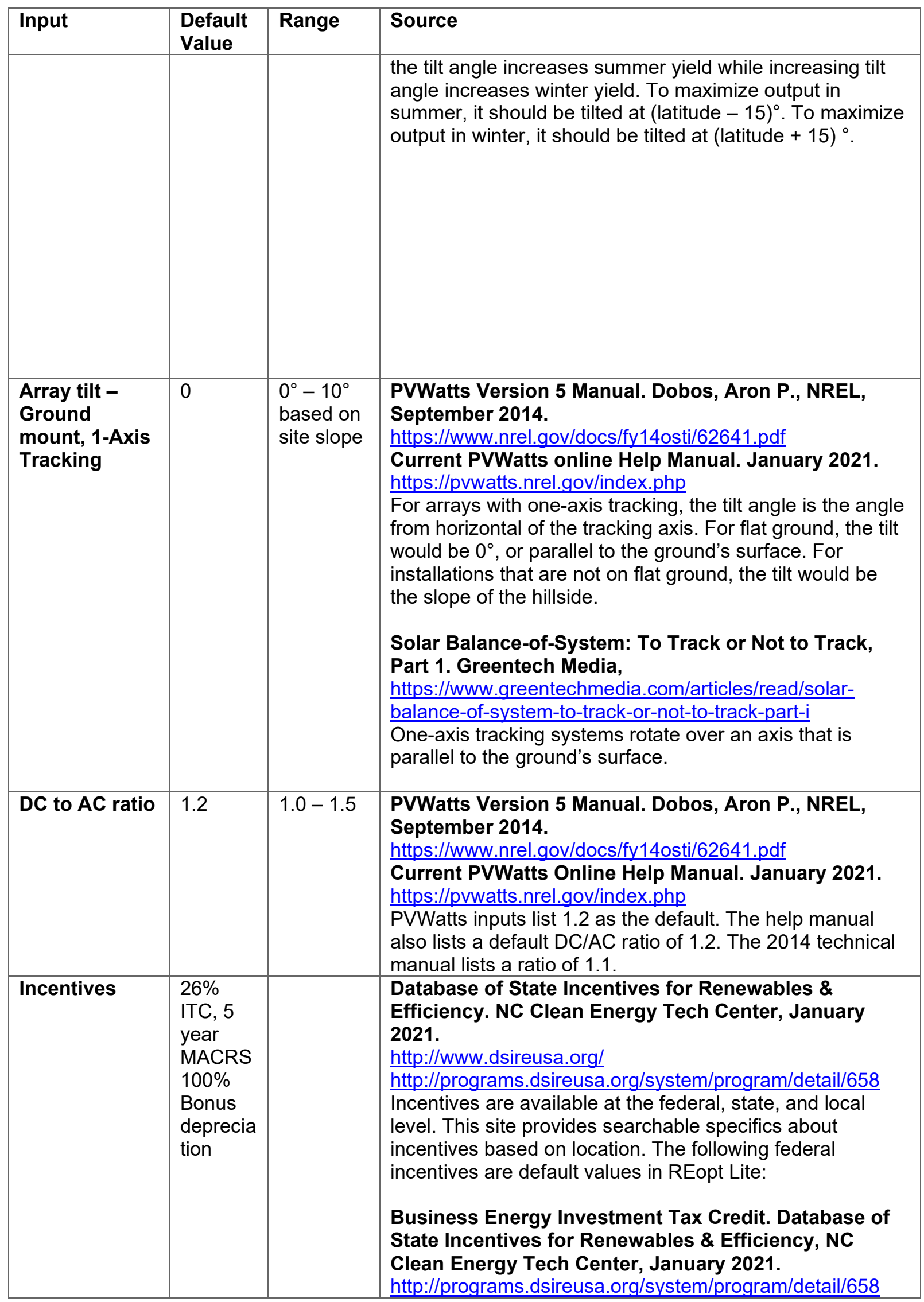




\begin{tabular}{|c|c|c|c|}
\hline Input & $\begin{array}{l}\text { Default } \\
\text { Value }\end{array}$ & Range & Source \\
\hline & & & $\begin{array}{l}\text { In } 2021 \text {, a federal } 26 \% \text { investment tax credit is available to } \\
\text { solar projects regardless of size, with no maximum } \\
\text { incentive for solar technologies. The credit was previously } \\
30 \% \text {. } \\
\text { Modified Accelerated Cost-Recovery System. } \\
\text { Database of State Incentives for Renewables \& } \\
\text { Efficiency, NC Clean Energy Tech Center, August } \\
2018 \text {. } \\
\text { http://programs.dsireusa.org/system/program/detail/676 } \\
\text { Solar projects are eligible for accelerated depreciation } \\
\text { deductions over a 5-year period, with bonus depreciation } \\
\text { of } 100 \% \text { in the first year. }\end{array}$ \\
\hline $\begin{array}{l}\text { System losses } \\
\text { - General }\end{array}$ & & & $\begin{array}{l}\text { Total losses calculated as }\left(1-(1-\text { loss } 1)^{\star}(1-\text { loss } 2)^{\star} \ldots{ }^{*}(1-\right. \\
\text { lossN) ) }\end{array}$ \\
\hline $\begin{array}{l}\text { System losses } \\
\text { - Soiling }\end{array}$ & $2 \%$ & $\begin{array}{l}2 \%- \\
25 \%\end{array}$ & $\begin{array}{l}\text { PVWatts Version } 5 \text { Manual. Dobos, Aron P., NREL, } \\
\text { September } 2014 . \\
\text { https://www.nrel.gov/docs/fy14osti/62641.pdf } \\
\text { Current PVWatts online Help Manual. January } 2021 . \\
\text { https://pvwatts.nrel.gov/index.php } \\
\text { PVWatts applies a default soiling loss of } 2 \% \text {. } \\
\text { Performance Parameters for Grid-Connected PV } \\
\text { Systems. NREL, February } 2005 . \\
\text { https://www.nrel.gov/docs/fy05osti/37358.pdf } \\
\text { Table } 1 \text { lists a typical soiling AC derate factor as } 0.95 \text {, with } \\
\text { a typical range of } 0.75-0.98 \text {. These values correspond to a } \\
\text { typical soiling loss of } 5 \% \text { with a typical range of } 2 \%-25 \% \text {. }\end{array}$ \\
\hline $\begin{array}{l}\text { System losses } \\
\text { - Shading }\end{array}$ & $3 \%$ & $\begin{array}{l}0 \%- \\
30 \%\end{array}$ & $\begin{array}{l}\text { PVWatts Version } 5 \text { Manual. Dobos, Aron P., NREL, } \\
\text { September } 2014 . \\
\text { https://www.nrel.gov/docs/fy14osti/62641.pdf } \\
\text { Current PVWatts Online Help Manual. January } 2021 . \\
\text { https://pvwatts.nrel.gov/index.php } \\
\text { PVWatts applies a default shading loss of } 3 \% \text {. } \\
\text { Photovoltaic Shading Testbed for Module-Level Power } \\
\text { Electronics: } 2016 \text { Performance Data Update. NREL } \\
\text { and PV Evolution Labs, September } 2016 \text {. } \\
\text { https://www.nrel.gov/docs/fy16osti/62471.pdf } \\
\text { Based on a survey of shading of residential PV systems, } \\
\text { this study classifies light shading as }<15 \% \text { annual shading } \\
\text { (7.6\% is representative of typical light shading), moderate } \\
\text { shading as } 15 \%-20 \% \text { annual shading (19\% is } \\
\text { representative of typical moderate shading), and heavy } \\
\text { shading as }>20 \% \text { annual shading ( } 25.5 \% \text { is representative } \\
\text { of typical heavy shading). If the shading increases to } \\
>30 \% \text { of the modules in a string, the maximum power point } \\
\text { tracking (MPPT) minimum voltage would be reached. }\end{array}$ \\
\hline
\end{tabular}




\begin{tabular}{|c|c|c|c|}
\hline Input & $\begin{array}{l}\text { Default } \\
\text { Value }\end{array}$ & Range & $\begin{array}{l}\text { Source } \\
\text { Performance Parameters for Grid-Connected PV } \\
\text { Systems. NREL, February } 2005 \text {. } \\
\text { https://www.nrel.gov/docs/fy05osti/37358.pdf } \\
\text { Table } 1 \text { lists a typical shading derate factor as } 0.975 \text { for } \\
\text { fixed-tilt rack-mounted systems. These values correspond } \\
\text { to a typical shading loss of } 2.5 \% \text {. }\end{array}$ \\
\hline $\begin{array}{l}\text { System losses } \\
\text { - Snow }\end{array}$ & $0 \%$ & $\begin{array}{l}0 \%- \\
15 \% \\
\text { typical in } \\
\text { US, } 0 \%- \\
100 \% \\
\text { possible }\end{array}$ & $\begin{array}{l}\text { PVWatts Version } 5 \text { Manual. Dobos, Aron P., NREL, } \\
\text { September } 2014 . \\
\text { https://www.nrel.gov/docs/fy14osti/62641.pdf } \\
\text { Current PVWatts Online Help Manual. January } 2021 . \\
\text { https://pvwatts.nrel.gov/index.php } \\
\text { PVWatts applies a default snow loss of } 0 \% \text {. } \\
\text { Integration, Validation, and Application of a PV Snow } \\
\text { Coverage Model in SAM. NREL, August 2017. } \\
\text { https://www.nrel.gov/docs/fy17osti/68705.pdf } \\
\text { Figures } 2 \text { and } 3 \text { show estimated snow losses for cities and } \\
\text { regions, respectively, of the United States. Appendices A } \\
\text { and B provide the respective data in more detail. }\end{array}$ \\
\hline $\begin{array}{l}\text { System losses } \\
\text { - Mismatch }\end{array}$ & $2 \%$ & $\begin{array}{l}1.5 \%- \\
3 \%\end{array}$ & $\begin{array}{l}\text { PVWatts Version } 5 \text { Manual. Dobos, Aron P., NREL, } \\
\text { September } 2014 . \\
\text { https://www.nrel.gov/docs/fy14osti/62641.pdf } \\
\text { Current PVWatts Online Help Manual. January } 2021 . \\
\text { https://pvwatts.nrel.gov/index.php } \\
\text { PVWatts applies a default mismatch loss of } 2 \% \text {. } \\
\text { Performance Parameters for Grid-Connected PV } \\
\text { Systems. NREL, February } 2005 \text {. } \\
\text { https://www.nrel.gov/docs/fy05osti/37358.pdf } \\
\text { Table } 1 \text { lists a typical mismatch derate factor as } 0.98, \text { with } \\
\text { a typical range of } 0.97-0.985 \text {. These values correspond to } \\
\text { a typical mismatch loss of } 2 \% \text { with a typical range of } 1.5 \%- \\
3 \% \text {. }\end{array}$ \\
\hline $\begin{array}{l}\text { System losses } \\
\text {-Wiring }\end{array}$ & $2 \%$ & $\begin{array}{l}0.7 \%- \\
2 \%\end{array}$ & $\begin{array}{l}\text { PVWatts Version } 5 \text { Manual. Dobos, Aron P., NREL, } \\
\text { September 2014. } \\
\text { https://www.nrel.gov/docs/fy14osti/62641.pdf } \\
\text { Current PVWatts Online Help Manual. January } 2021 . \\
\text { https://pvwatts.nrel.gov/index.php } \\
\text { PVWatts applies a default wiring loss of } 2 \% \text {. } \\
\text { Performance Parameters for Grid-Connected PV } \\
\text { Systems. NREL, February } 2005 . \\
\text { https://www.nrel.gov/docs/fy05osti/37358.pdf } \\
\text { Table } 1 \text { lists a typical wiring derate factor as } 0.99, \text { with a } \\
\text { typical range of } 0.98-0.993 \text {. These values correspond to a } \\
\text { typical wiring loss of } 1 \% \text { with a typical range of } 0.7 \%-2 \% \text {. }\end{array}$ \\
\hline $\begin{array}{l}\text { System losses } \\
\text { - Connection }\end{array}$ & $0.5 \%$ & $\begin{array}{l}0.3 \%- \\
0.1 \%\end{array}$ & $\begin{array}{l}\text { PVWatts Version } 5 \text { Manual. Dobos, Aron P., NREL, } \\
\text { September 2014. } \\
\text { https://www.nrel.gov/docs/fy14osti/62641.pdf } \\
\text { Current PVWatts Online Help Manual. January } 2021 .\end{array}$ \\
\hline
\end{tabular}




\begin{tabular}{|c|c|c|c|}
\hline Input & $\begin{array}{l}\text { Default } \\
\text { Value }\end{array}$ & Range & Source \\
\hline & & & $\begin{array}{l}\text { https://pvwatts.nrel.gov/index.php } \\
\text { PVWatts applies a default connection loss of } 0.5 \% \text {. } \\
\text { Performance Parameters for Grid-Connected PV } \\
\text { Systems. NREL, February } 2005 \text {. } \\
\text { https://www.nrel.gov/docs/fy } 05 \text { osti/37358.pdf } \\
\text { Table } 1 \text { lists a typical diodes and connections derate factor } \\
\text { as } 0.995 \text {, with a typical range of } 0.99-0.997 \text {. These values } \\
\text { correspond to a typical connection loss of } 0.5 \% \text { with a } \\
\text { typical range of } 0.3 \%-1 \% \text {. }\end{array}$ \\
\hline $\begin{array}{l}\text { System losses } \\
\text { - Light- } \\
\text { induced } \\
\text { degradation } \\
\text { (LID) }\end{array}$ & $1.5 \%$ & $\begin{array}{l}0.3 \%- \\
10 \%\end{array}$ & $\begin{array}{l}\text { PVWatts Version } 5 \text { Manual. Dobos, Aron P., NREL, } \\
\text { September } 2014 . \\
\text { https://www.nrel.gov/docs/fy14osti/62641.pdf } \\
\text { Current PVWatts Online Help Manual. January } 2021 . \\
\text { https://pvwatts.nrel.gov/index.php } \\
\text { PVWatts applies a default light-induced degradation loss } \\
\text { of 1.5\%. } \\
\text { Performance Parameters for Grid-Connected PV } \\
\text { Systems. NREL, February } 2005 . \\
\text { https://www.nrel.gov/docs/fy05osti/37358.pdf } \\
\text { Table } 1 \text { lists a typical LID derate factor as } 0.98, \text { with a } \\
\text { typical range of } 0.90-0.99 \text {. These values correspond to a } \\
\text { typical mismatch loss of } 2 \% \text { with a typical range of } 1 \%- \\
10 \% \text {. }\end{array}$ \\
\hline $\begin{array}{l}\text { System losses } \\
\text { - Nameplate } \\
\text { Rating }\end{array}$ & $1 \%$ & $\begin{array}{l}-5 \%- \\
15 \%\end{array}$ & $\begin{array}{l}\text { PVWatts Version } 5 \text { Manual. Dobos, Aron P., NREL, } \\
\text { September } 2014 . \\
\text { https://www.nrel.gov/docs/fy14osti/62641.pdf } \\
\text { Current PVWatts Online Help Manual. January } 2021 . \\
\text { https://pvwatts.nrel.gov/index.php } \\
\text { PVWatts applies a default nameplate rating loss of } 1 \% \text {. } \\
\text { Performance Parameters for Grid-Connected PV } \\
\text { Systems. NREL, February } 2005 \text {. } \\
\text { https://www.nrel.gov/docs/fy05osti/37358.pdf } \\
\text { Table } 1 \text { lists a typical nameplate rating derate factor as } \\
\text { 1.0, with a typical range of } 0.85-1.05 \text {. These values } \\
\text { correspond to a typical nameplate rating loss of } 0 \% \text { with a } \\
\text { typical range of }-5 \%-15 \% \text {. }\end{array}$ \\
\hline $\begin{array}{l}\text { System losses } \\
\text { - Age }\end{array}$ & $0 \%$ & $\begin{array}{l}0 \%- \\
100 \%\end{array}$ & $\begin{array}{l}\text { PVWatts Version } 5 \text { Manual. Dobos, Aron P., NREL, } \\
\text { September 2014. } \\
\text { https://www.nrel.gov/docs/fy14osti/62641.pdf } \\
\text { Current PVWatts Online Help Manual. January } 2021 . \\
\text { https://pvwatts.nrel.gov/index.php } \\
\text { PVWatts applies a default loss due to age of 0\%. }\end{array}$ \\
\hline $\begin{array}{l}\text { System losses } \\
\text { - Availability }\end{array}$ & $3 \%$ & $\begin{array}{l}0.5 \%- \\
100 \%\end{array}$ & $\begin{array}{l}\text { PVWatts Version } 5 \text { Manual. Dobos, Aron P., NREL, } \\
\text { September 2014. } \\
\text { https://www.nrel.gov/docs/fy14osti/62641.pdf }\end{array}$ \\
\hline
\end{tabular}




\begin{tabular}{|c|c|c|c|}
\hline Input & $\begin{array}{l}\text { Default } \\
\text { Value }\end{array}$ & Range & Source \\
\hline & & & $\begin{array}{l}\text { Current PVWatts Online Help Manual. January } 2021 . \\
\text { https://pvwatts.nrel.gov/index.php } \\
\text { PVWatts applies a default availability loss of } 3 \% \text {. } \\
\text { Performance Parameters for Grid-Connected PV } \\
\text { Systems. NREL, February } 2005 \text {. } \\
\text { https://www.nrel.gov/docs/fy } 05 \text { osti/37358.pdf } \\
\text { Table } 1 \text { lists a typical availability derate factor as } 0.98 \text {, with } \\
\text { a typical range of } 0-0.995 . \text { These values correspond to a } \\
\text { typical availability loss of } 2 \% \text { with a typical range of } 0.5 \%- \\
100 \% \text {. }\end{array}$ \\
\hline
\end{tabular}

Table 24. Battery Storage Inputs, Default Values, Ranges, and Sources

Note: All values listed assume the use of lithium-ion battery systems

\begin{tabular}{|c|c|c|c|}
\hline Input & $\begin{array}{l}\text { Default } \\
\text { Value }\end{array}$ & Range & Source \\
\hline $\begin{array}{l}\text { Energy } \\
\text { capacity cost } \\
\text { (\$/kWh) }\end{array}$ & $\$ 420$ & $\begin{array}{l}\$ 319- \\
\$ 700\end{array}$ & 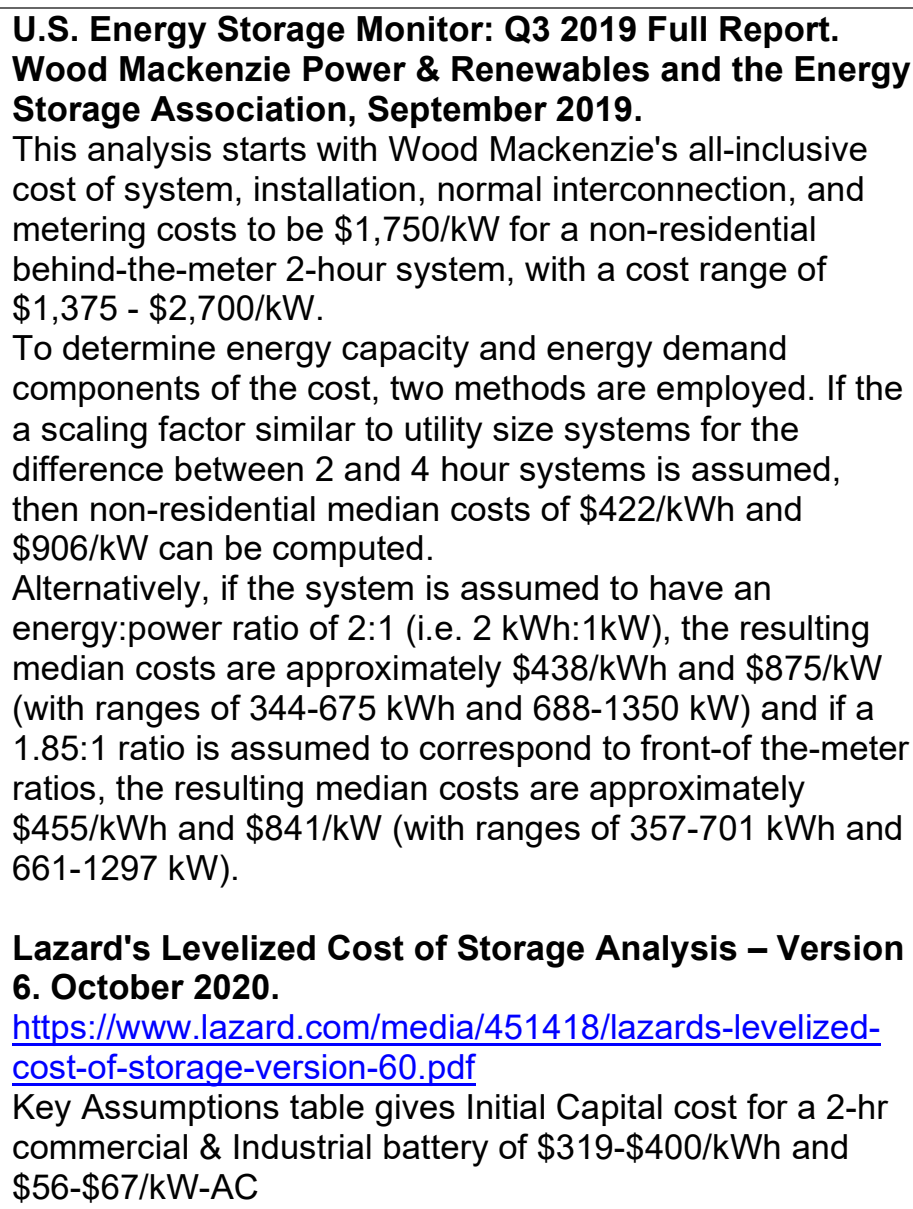 \\
\hline
\end{tabular}




\begin{tabular}{|c|c|c|c|}
\hline Input & $\begin{array}{l}\text { Default } \\
\text { Value }\end{array}$ & Range & Source \\
\hline $\begin{array}{l}\text { Power } \\
\text { capacity cost } \\
(\$ / k W)\end{array}$ & $\$ 840$ & $\begin{array}{l}\$ 56- \\
\$ 1350\end{array}$ & See above description of basis for energy capacity cost. \\
\hline $\begin{array}{l}\text { Battery } \\
\text { energy } \\
\text { capacity } \\
\text { replacement } \\
\text { cost }(\$ / k W h)\end{array}$ & $\$ 200$ & $\begin{array}{l}\$ 162- \\
\$ 340\end{array}$ & $\begin{array}{l}\text { U.S. Energy Storage Monitor: Q3 } 2019 \text { Full Report. } \\
\text { Wood Mackenzie Power \& Renewables and the Energy } \\
\text { Storage Association, September } 2019 . \\
\text { Woods Mackenzie predicts a decline in price of } 20-25 \% \text { in } \\
\text { the next } 2 \text { years for front-of-the meter storage, but more } \\
\text { flat costs for behind-the-meter, due to supply constraints, } \\
\text { in the } 1-3 \% \text { decline range. Once supply constraints are } \\
\text { removed, the cost decline is likely to improve. } \\
\text { Replacement costs need to be estimated for } 10 \text { years out. } \\
\text { Conservatively decline may be expected in the } 7 \% \text { per } \\
\text { year range. } \\
\text { Energy Storage Technology and Cost Characterization } \\
\text { Report. Pacific Northwest National Laboratory. July } \\
2019 \\
\text { https://www.pnnl.gov/main/publications/external/technical } \\
\text { reports/PNNL-28866.pdf } \\
\text { A cost drop of } 5 \% \text { per year was assumed to be a } \\
\text { conservative estimate for batteries on the lower end of the } \\
\text { cost range. This is in light of significant cost drops seen in } \\
\text { the past } 10 \text { years. }\end{array}$ \\
\hline $\begin{array}{l}\text { Energy } \\
\text { capacity } \\
\text { replacement } \\
\text { year }\end{array}$ & 10 & $9-20$ & $\begin{array}{l}\text { Because the replacement timeline for Li-ion batteries is } \\
\text { impacted by the SOC at which it is utilized, the } \\
\text { replacement year is difficult to predict. REopt Lite does not } \\
\text { currently account for battery degradation or loss of } \\
\text { capacity over time in its dispatch and energy/power } \\
\text { calculations, but allows the user to input a replacement } \\
\text { year. The Year } 10 \text { replacement default assumes that the } \\
\text { technology for this replacement will have improved to the } \\
\text { point that it will last for the remaining } 15 \text { years of the } \\
\text { default } 25 \text {-year analysis period. } \\
\text { Economic Analysis Case Studies of Battery Energy } \\
\text { Storage with SAM. NREL, November } 2015 . \\
\text { https://www.nrel.gov/docs/fy16osti/64987.pdf } \\
\text { Uses the Tesla Powerwall specifications as an example } \\
\text { and estimates that it will last } 5 \text { years longer than its } 10- \\
\text { year warranty. At one cycle per day, this amounts to } \\
\text { approximately } 5,475 \text { cycles. } \\
\text { Energy Storage Technology and Cost Characterization } \\
\text { Report. Pacific Northwest National Laboratory. July } \\
\text { 2019 } \\
\text { https://www.pnnl.gov/main/publications/external/technical } \\
\text { reports/PNNL-28866.pdf } \\
\text { A survey of the literature suggests the lower end of the } \\
\text { typical suggested range of } 10-20 \text { life years. }\end{array}$ \\
\hline $\begin{array}{l}\text { Power } \\
\text { capacity }\end{array}$ & $\$ 410$ & $\begin{array}{l}\$ 76- \\
\$ 653\end{array}$ & $\begin{array}{l}\text { See above description of basis for energy capacity } \\
\text { replacement cost. }\end{array}$ \\
\hline
\end{tabular}




\begin{tabular}{|c|c|c|c|}
\hline Input & $\begin{array}{l}\text { Default } \\
\text { Value }\end{array}$ & Range & Source \\
\hline \multicolumn{4}{|l|}{$\begin{array}{l}\text { replacement } \\
\text { cost }(\$ / k W)\end{array}$} \\
\hline $\begin{array}{l}\text { Power } \\
\text { capacity } \\
\text { replacement } \\
\text { year }\end{array}$ & 10 & $9-20$ & $\begin{array}{l}\text { See above description of basis for energy capacity } \\
\text { replacement year. }\end{array}$ \\
\hline $\begin{array}{l}\text { Rectifier } \\
\text { efficiency (\%) }\end{array}$ & $96 \%$ & & $\begin{array}{l}\text { An integrated approach for the analysis and control of } \\
\text { grid connected energy storage systems. Journal of } \\
\text { Energy Storage, Volume 5, February } 2016 \text {. } \\
\frac{\text { http://www.sciencedirect.com/science/article/pii/S2352152 }}{\mathrm{X} 15300335} \\
\text { Depending on the SOC, the converter efficiency of a } \\
100 \mathrm{~kW} / 50 \mathrm{kWh} \text { lithium-ion system was found to sit around } \\
96 \% \text { for SOCs of } 30-100 \% \text {, as illustrated in Figure } 14 \text {. } \\
\text { The efficiency of this converter is applied to both the } \\
\text { inverter and rectifier in REopt Lite. }\end{array}$ \\
\hline $\begin{array}{l}\text { Round trip } \\
\text { efficiency }(\%)\end{array}$ & $97.5 \%$ & $\begin{array}{l}95 \%- \\
98 \%\end{array}$ & $\begin{array}{l}\text { An integrated approach for the analysis and control of } \\
\text { grid connected energy storage systems. Journal of } \\
\text { Energy Storage, Volume 5, February } 2016 \text {. } \\
\text { http://www.sciencedirect.com/science/article/pii/S2352152 } \\
\text { X15300335 } \\
\text { Depending on the SOC, the battery efficiency of a } \\
100 \mathrm{~kW} / 50 \mathrm{kWh} \text { lithium-ion system was found to vary } \\
\text { between } 97 \% \text { and } 98 \% \text { for SOCs of } 30 \%-100 \% \text {, as } \\
\text { illustrated in Figure } 14 . \\
\text { Lithium Batteries and Other Electrochemical Storage } \\
\text { Systems. Glazie, Christian and Geniès, Sylvie, August } \\
\text { 2013. } \\
\text { http://onlinelibrary.wiley.com/doi/10.1002/9781118761120. } \\
\text { ch6/pdf } \\
\text { The efficiency depends on the battery's state of charge } \\
\text { and it's charge/discharge conditions (voltage, rate of } \\
\text { charge/discharge, temperature), especially at high or low } \\
\text { SOC. The following values give average efficiencies at } \\
\text { mid-range SOCs. } \\
\text { 95\% for C-LiFePO }{ }_{4}-\text { see Section } 6.2 .18 \text {. } \\
\text { 98\% for C-Li(Co,Ni) } \mathrm{O}_{2}-\text { see Section } 6.2 .18 \text {. }\end{array}$ \\
\hline $\begin{array}{l}\text { Inverter } \\
\text { efficiency (\%) }\end{array}$ & 96 & & $\begin{array}{l}\text { An integrated approach for the analysis and control of } \\
\text { grid connected energy storage systems. Journal of } \\
\text { Energy Storage, Volume 5, February } 2016 \text {. } \\
\text { http://www.sciencedirect.com/science/article/pii/S2352152 } \\
\frac{\mathrm{X} 15300335}{\text { Depending on the SOC, the converter efficiency of a }} \\
100 \mathrm{~kW} / 50 \mathrm{kWh} \text { lithium-ion system was found to sit around } \\
96 \% \text { for SOCs of } 30-100 \% \text {, as illustrated in Figure } 14 \text {. } \\
\text { The efficiency of this converter is applied to both the } \\
\text { inverter and rectifier in REopt Lite. }\end{array}$ \\
\hline
\end{tabular}




\begin{tabular}{|c|c|c|c|}
\hline Input & $\begin{array}{l}\text { Default } \\
\text { Value }\end{array}$ & Range & Source \\
\hline $\begin{array}{l}\text { Minimum } \\
\text { state of } \\
\text { charge (\%) }\end{array}$ & 20 & $\begin{array}{l}15 \%- \\
30 \%\end{array}$ & $\begin{array}{l}\text { An integrated approach for the analysis and control of } \\
\text { grid connected energy storage systems. Journal of } \\
\text { Energy Storage, Volume 5, February } 2016 \text {. } \\
\text { http://www.sciencedirect.com/science/article/pii/S2352152 } \\
\mathrm{X} 15300335 \\
\text { When the state of charge of a lithium-ion battery drops } \\
\text { below } 20 \% \text {, the voltage drops rapidly and impedance, } \\
\text { which reduces round trip efficiency and generates heat, so } \\
\text { optimal performance is achieved above } 20 \% \text { SOC. }\end{array}$ \\
\hline Incentives & $\begin{array}{l}0 \% \text { ITC, } \\
7 \text { year } \\
\text { MACRS } \\
100 \% \\
\text { Bonus } \\
\text { deprecia } \\
\text { tion }\end{array}$ & & 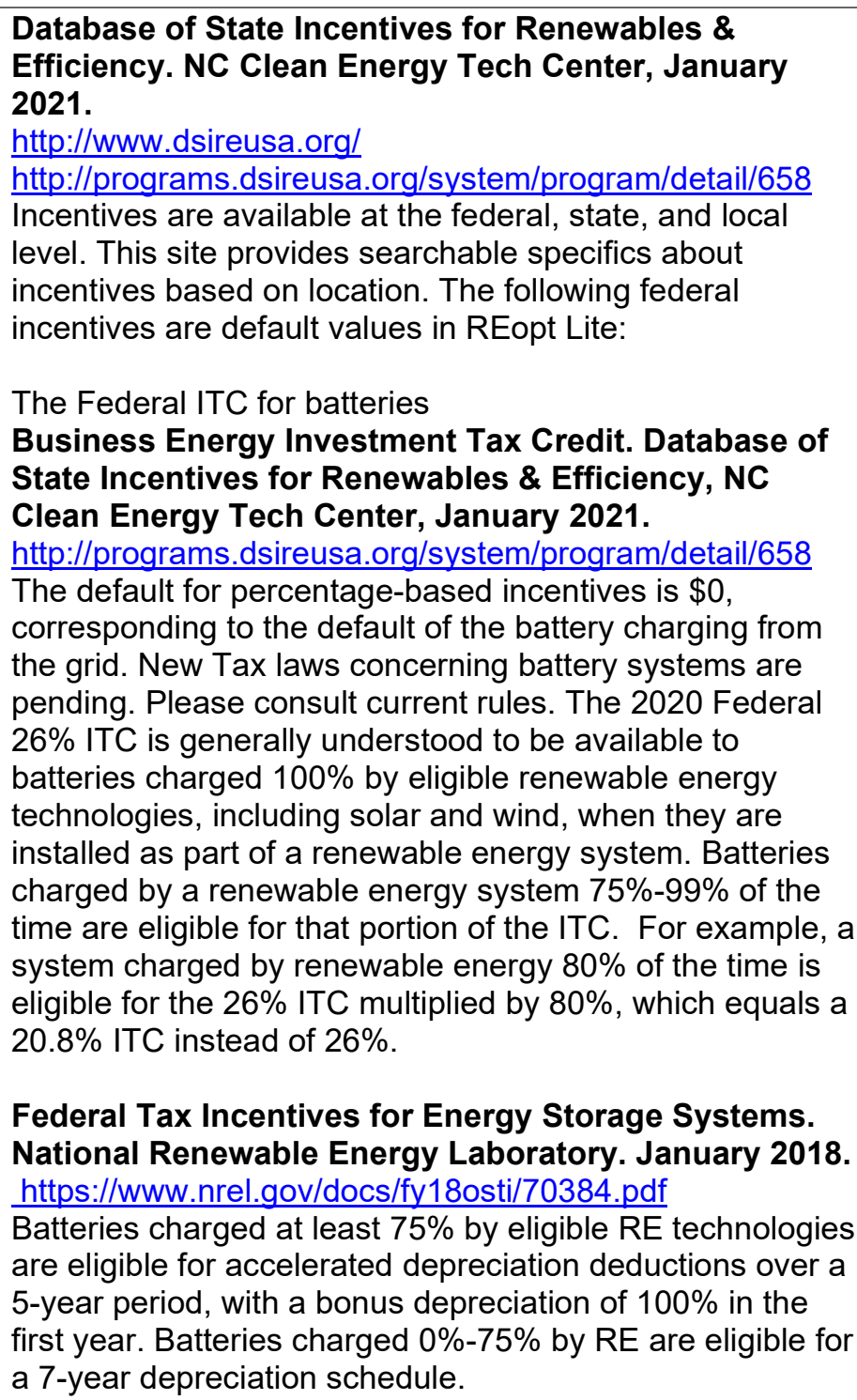 \\
\hline
\end{tabular}


Table 25. Wind Inputs, Default Values, Ranges, and Sources

\begin{tabular}{|c|c|c|c|}
\hline Input & $\begin{array}{l}\text { Default } \\
\text { Value }\end{array}$ & Range & Source \\
\hline $\begin{array}{l}\text { Wind size } \\
\text { class }\end{array}$ & $\begin{array}{l}\text { Comm } \\
(21 \mathrm{~kW}- \\
100 \mathrm{~kW}\end{array}$ & $\begin{array}{l}2.5 \mathrm{~kW}- \\
2,000 \mathrm{~kW}\end{array}$ & 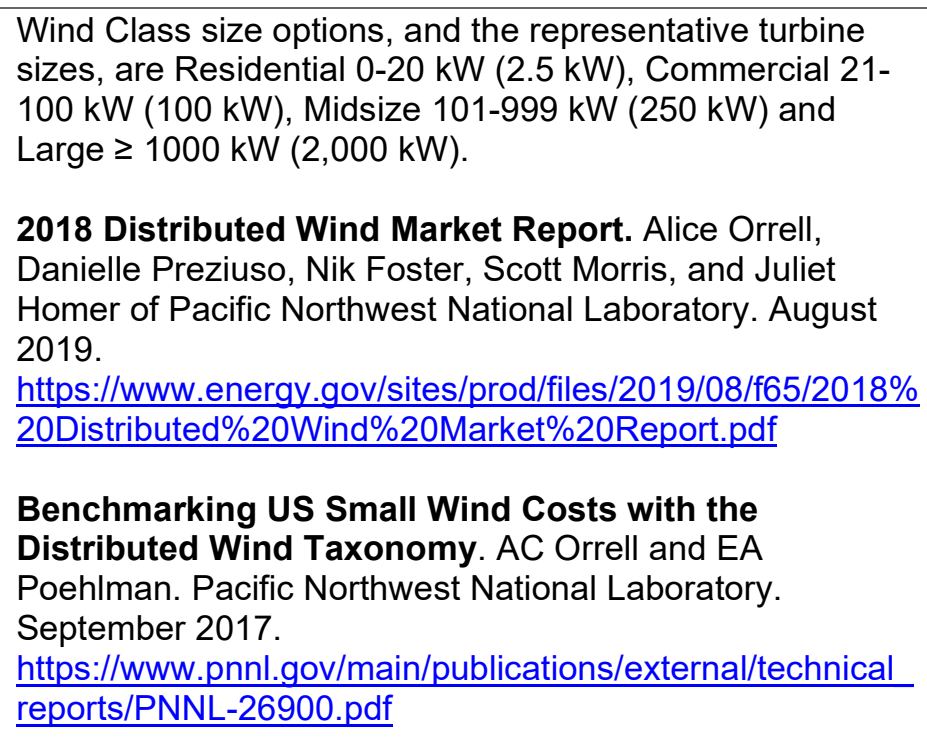 \\
\hline $\begin{array}{l}\text { System } \\
\text { capital cost } \\
\text { (\$/kW) Class }\end{array}$ & $\begin{array}{l}\text { Comm } \\
\$ 7390\end{array}$ & $\begin{array}{l}\text { Res - } \\
\$ 11,950 \\
\text { Comm - } \\
\$ 7,390 \\
\text { Midsize - } \\
\$ 4,440 \\
\text { Large - } \\
\$ 3,450\end{array}$ & $\begin{array}{l}\text { Wind CAPEX Defaults change depending on the Wind } \\
\text { Class size chosen: Residential ( } \$ 11,950 / \mathrm{kW}) \text {, Commercial } \\
\text { ( } \$ 7,390 / \mathrm{kW}) \text {, Midsize }(\$ 4,440 / \mathrm{kW}) \text { and Large }(\$ 3,450 / \mathrm{kW}) \text {. } \\
\text { If no Wind Class is chosen, the default is the Commercial } \\
\text { size, which has a default of } \$ 7,390 \text {. } \\
\text { Benchmarking U.S. Small Wind Costs gives } 2016 \\
\text { values for Residential } \$ 11,953 \text {, Commercial } \$ 7,389 \\
\text { Benchmarking US Small Wind Costs with the } \\
\text { Distributed Wind Taxonomy. AC Orrell and EA } \\
\text { Poehlman. Pacific Northwest National Laboratory. } \\
\text { September } 2017 \text {. } \\
\text { https://www.pnnl.gov/main/publications/external/technical } \\
\text { reports/PNNL-26900.pdf } \\
\text { Distributed Wind Market Report gives average for small } \\
\text { wind <100 kW of } 2017 \$ 10,030 / \mathrm{kW} \text { and average for }>100 \\
\text { kW of } 2018 \$ 4,437 / \mathrm{kW} \text {. The Distributed Wind Market } \\
\text { Report does not include a cost for large turbines, but the } \\
\text { database used for the report indicates an average for } \\
\text { single large turbine projects in } 2016 / 2017 \text { of } \$ 3,450 \text {. } \\
\text { 2018 Distributed Wind Market Report. Alice Orrell, } \\
\text { Danielle Preziuso, Nik Foster, Scott Morris, and Juliet } \\
\text { Homer of Pacific Northwest National Laboratory. August } \\
2019 . \\
\text { https://www.energy.gov/sites/prod/files/2019/08/f65/2018\% } \\
\text { 20Distributed\%20Wind\%20Market\%20Report.pdf } \\
\text { Wind Technologies Market Report gives average } \\
\text { installed project costs of } \$ 1,743 / \mathrm{kW} \text { for turbines in the } \\
\text { 1,500 kW-2,000 kW size range, but these represent larger }\end{array}$ \\
\hline
\end{tabular}




\begin{tabular}{|c|c|c|c|}
\hline Input & $\begin{array}{l}\text { Default } \\
\text { Value }\end{array}$ & Range & Source \\
\hline & & & $\begin{array}{l}\text { installations that could take advantage of economies of } \\
\text { scale. } \\
\mathbf{2 0 1 8} \text { Wind Technologies Market Report. Ryan Wiser } \\
\text { and Mark Bolinger. Lawrence Berkeley National } \\
\text { Laboratory. August 2019. https://eta- } \\
\text { publications.lbl.gov/sites/default/files/wtmr final for postin } \\
\underline{\text { g } 8-9-19 . p d f} \\
\mathbf{2 0 2 0} \text { Annual Technology Baseline and Standard } \\
\text { Scenarios. NREL, 2020. } \\
\text { https://atb.nrel.gov/ } \\
\text { The NREL ATB projects } 2021 \text { moderate CAPEX of } \\
\text { \$1,642, but this also assumes a large installation. }\end{array}$ \\
\hline $\begin{array}{l}\text { O\&M cost } \\
\text { (\$/kW/year) }\end{array}$ & $\$ 40$ & $\$ 18-\$ 59$ & $\begin{array}{l}\text { Distributed Wind Market Report uses } \$ 40 / \mathrm{kW} / \mathrm{yr} \text { with } \\
\text { reference to NREL's Assessing the Future of Distributed } \\
\text { Wind } 2016 \text { values of } \$ 30-\$ 40 \text {. } \\
2018 \text { Distributed Wind Market Report. Alice Orrell, } \\
\text { Danielle Preziuso, Nik Foster, Scott Morris, and Juliet } \\
\text { Homer of Pacific Northwest National Laboratory. August } \\
2019 . \\
\text { https://www.energy.gov/sites/prod/files/2019/08/f65/2018\% } \\
\text { 20Distributed\%20Wind\%20Market\%20Report.pdf } \\
2020 \text { Annual Technology Baseline and Standard } \\
\text { Scenarios. NREL, 2020. } \\
\text { https://atb.nrel.gov/ } \\
\text { The NREL } 2020 \text { ATB projects a } 2021 \text { moderate O\&M cost } \\
\text { of } \$ 42 / k W / y r . \\
\text { Wind Technologies Market Report gives a } \$ 33-\$ 59 \text { range } \\
\text { with a mid-point of } \$ 44 / k W / y r . \\
\text { 2018 Wind Technologies Market Report. Ryan Wiser } \\
\text { and Mark Bolinger. Lawrence Berkeley National } \\
\text { Laboratory. August } 2019 \text {.https://eta- } \\
\text { publications.Ibl.gov/sites/default/files/wtmr final for postin } \\
\text { g 8-9-19.pdf }\end{array}$ \\
\hline Incentives & $\begin{array}{l}26 \% \\
\text { ITC for } \\
\text { small } \\
\text { wind to } \\
100 \mathrm{~kW} \\
\text { and } \\
18 \% \text { for } \\
\text { larger } \\
\text { wind } \\
5 \text { year } \\
\text { MACRS } \\
100 \% \\
\text { bonus } \\
\text { deprecia } \\
\text { tion }\end{array}$ & & $\begin{array}{l}\text { Database of State Incentives for Renewables \& } \\
\text { Efficiency. NC Clean Energy Tech Center, January } \\
2021 . \\
\text { http://www.dsireusa.org/ } \\
\text { http://programs.dsireusa.org/system/program/detail/658 } \\
\text { Incentives are available at the federal, state, and local } \\
\text { level. This site provides searchable specifics about } \\
\text { incentives based on location. The following federal } \\
\text { incentives are default values in REopt Lite: } \\
\text { Business Energy Investment Tax Credit (ITC). } \\
\text { Database of State Incentives for Renewables \& } \\
\text { Efficiency, NC Clean Energy Tech Center, January } \\
\text { 2021. } \\
\text { http://programs.dsireusa.org/system/program/detail/658 }\end{array}$ \\
\hline
\end{tabular}




\begin{tabular}{|c|c|c|c|}
\hline Input & \begin{tabular}{|l|} 
Default \\
Value
\end{tabular} & Range & Source \\
\hline & & & $\begin{array}{l}\text { In } 2020 \text {, a federal } 26 \% \text { investment tax credit is available to } \\
\text { wind projects up to } 100 \mathrm{~kW} \text { in capacity and } 18 \% \text { for larger } \\
\text { wind systems. The ITC is discontinued in } 2022 \text { for larger } \\
\text { wind systems. } \\
\text { Modified Accelerated Cost-Recovery System } \\
\text { (MACRS). Database of State Incentives for } \\
\text { Renewables \& Efficiency, NC Clean Energy Tech } \\
\text { Center, August } 2018 \text {. } \\
\text { http://programs.dsireusa.org/system/program/detail/676 } \\
\text { Wind projects are eligible for accelerated depreciation } \\
\text { deductions over a } 5 \text {-year period, with bonus depreciation } \\
\text { of } 100 \% \text { in the first year. The provision which defines ITC } \\
\text { technologies as eligible also adds the general term "wind" } \\
\text { as an eligible technology, extending the five-year schedule } \\
\text { to large wind facilities as well. }\end{array}$ \\
\hline
\end{tabular}

Table 26. Resilience Evaluations- Load Profile Inputs, Default Values, Ranges, and Sources

\begin{tabular}{|l|c|l|l|}
\hline Input & $\begin{array}{l}\text { Default } \\
\text { Value }\end{array}$ & Range & Source \\
\hline $\begin{array}{l}\text { Critical load } \\
\text { factor (\%) }\end{array}$ & $50 \%$ & $\begin{array}{l}10 \%- \\
100 \%\end{array}$ & The critical load varies widely based on building use. \\
\hline
\end{tabular}

Table 27. Resilience Evaluations- Generator Inputs, Default Values, Ranges, and Sources

\begin{tabular}{|l|l|l|l|}
\hline Input & $\begin{array}{l}\text { Default } \\
\text { Value }\end{array}$ & Range & Source \\
\hline $\begin{array}{l}\text { Install cost } \\
\text { \$/kW) }\end{array}$ & $\$ 500$ & $\begin{array}{l}\$ 238- \\
\$ 800\end{array}$ & $\begin{array}{l}\text { 2019 RSMeans Building Construction Cost Data. 77th } \\
\text { Annual Edition. Gordian Group. Reference: Packaged } \\
\text { Generator Assemblies. Engine Generators. Diesel- } \\
\text { Engine-Driven Generator Sets. } \\
\text { Total installing contractor costs, including overhead and } \\
\text { profit, range from \$238/kW for a 500 kW system to } \\
\$ 527 / \mathrm{kW} \text { for a 30 kW system. }\end{array}$ \\
& & $\begin{array}{l}\text { Lazard's Levelized Cost of Energy Analysis-Version } \\
11.0 . \text { November 2017. (NOTE: 2020 version doesn't } \\
\text { include diesel analysis) } \\
\text { https://www.lazard.com/media/450337/lazard-levelized- }\end{array}$ \\
& $\begin{array}{l}\text { cost-of-energy-version-110.pdf } \\
\text { For an output of 250-1000 kW, the total capital costs } \\
\text { average \$500-\$800/kW. Costs may assume Tier 4 } \\
\text { compliance costs of adding emission control systems for } \\
\text { prime applications as well as emergency backup. }\end{array}$ \\
\hline $\begin{array}{l}\text { Diesel cost } \\
\text { (\$/gal) }\end{array}$ & $\$ 3$ & $\begin{array}{l}\$ 2.50- \\
\$ 3.27\end{array}$ & $\begin{array}{l}\text { Cost Reference Guide for Construction Equipment: } \\
\text { The Standard Reference for Estimating Owning and } \\
\text { Operating Costs for all Classes of Construction } \\
\text { Equipment. 1st Half 2019. EquipmentWatch. } \\
\text { Diesel = \$3.27/gal }\end{array}$ \\
\hline & &
\end{tabular}




\begin{tabular}{|c|c|c|c|}
\hline Input & $\begin{array}{l}\text { Default } \\
\text { Value }\end{array}$ & Range & Source \\
\hline & & & $\begin{array}{l}\text { Lazard's Levelized Cost of Energy Analysis-Version } \\
\text { 11.0. November 2017. (NOTE: } 2020 \text { version doesn't } \\
\text { include diesel analysis) } \\
\text { https://www.lazard.com/media/450337/lazard-levelized- } \\
\text { cost-of-energy-version-110.pdf } \\
\text { Diesel price of } \sim \$ 2.50 / \text { gal }\end{array}$ \\
\hline $\begin{array}{l}\text { Fuel } \\
\text { availability } \\
\text { (gallons) }\end{array}$ & 660 & $1.4-660$ & $\begin{array}{l}\text { National Fire Prevention Association code NFPA 110: } \\
\text { Standard for Emergency and Standby Power Systems, } \\
2019 \text { Edition, Section } 110-17 \text { 7.9.5. Integral tanks up to a } \\
\text { maximum of } 660 \text { gallons for diesel fuel are permitted } \\
\text { inside or on roofs of structures. } \\
\text { https://www.nfpa.org/codes-and-standards/all-codes-and- } \\
\text { standards/list-of-codes-and-standards/detail?code=110 } \\
\text { Some critical facilities such as hospitals are required to } \\
\text { have } 96 \text { hours of fuel. Users can change the default } \\
\text { depending on their building requirements. } \\
\text { https://www.facilitiesnet.com/healthcarefacilities/article/NF } \\
\text { PA-110s-Fuel-Requirements-Can-Help-Guide-Backup- } \\
\text { Power-Plan-For-Hospitals--14338 }\end{array}$ \\
\hline $\begin{array}{l}\text { Fixed O\&M } \\
\text { (\$/kW/yr) }\end{array}$ & $\$ 10$ & $\$ 10-\$ 35$ & $\begin{array}{l}\text { Lazard's Levelized Cost of Energy Analysis-Version } \\
\text { 11.0. November 2017. (NOTE: } 2020 \text { version doesn't } \\
\text { include diesel analysis) } \\
\text { https://www.lazard.com/media/450337/lazard-levelized- } \\
\text { cost-of-energy-version-110.pdf } \\
\text { For an output of } 250-1000 \mathrm{~kW} \text {, the Key Assumptions table } \\
\text { lists a fixed O\&M at } \$ 10 / \mathrm{kW} / \mathrm{yr} \text {. For a back-up generator, } \\
\text { these costs are assumed to be small, primarily based on } \\
\text { regular monthly maintenance. }\end{array}$ \\
\hline $\begin{array}{l}\text { Variable O\&M } \\
\text { (\$/kWh) }\end{array}$ & $\$ 0.00$ & $\begin{array}{l}\$ 0.005- \\
\$ 0.01\end{array}$ & $\begin{array}{l}\text { Lazard's Levelized Cost of Energy Analysis-Version } \\
\text { 11.0. November 2017. (NOTE: } 2020 \text { version doesn't } \\
\text { include diesel analysis) } \\
\text { https://www.lazard.com/media/450337/lazard-levelized- } \\
\text { cost-of-energy-version-110.pdf } \\
\text { For an output of } 250-1000 \mathrm{~kW} \text {, the Key Assumptions table } \\
\text { lists a variable O\&M of } \$ 0.01 / \mathrm{kWh} \text {. } \\
\text { However, these cited costs are based on regular generator } \\
\text { use. The generator modeled in REopt Lite is a backup } \\
\text { generator, with limited use, therefore the default for these } \\
\text { costs is set to } \$ 0 / \mathrm{kWh} \text {. The user can set a higher value if } \\
\text { the generator will be used more extensively. }\end{array}$ \\
\hline $\begin{array}{l}\text { Fuel burn rate } \\
\text { by generator } \\
\text { capacity } \\
\text { (gal/kWh) }\end{array}$ & 0.076 & $\begin{array}{l}0.069- \\
0.172\end{array}$ & $\begin{array}{l}\text { Generator Source Website: Approximate Diesel Fuel } \\
\text { Consumption Chart. February } 2021 \\
\text { https://www.generatorsource.com/Diesel Fuel Consumpti } \\
\text { on.aspx } \\
\text { A constant specific fuel consumption rate default across } \\
\text { generator sizes and load conditions is used due to fuel's } \\
\text { relatively small percentage of the lifecycle cost for a } \\
\text { generator used only as backup power in a grid outage and } \\
\text { also due to the resulting significant positive impact on }\end{array}$ \\
\hline
\end{tabular}




\begin{tabular}{|l|l|l|l|}
\hline Input & $\begin{array}{l}\text { Default } \\
\text { Value }\end{array}$ & Range & Source \\
\hline & & $\begin{array}{l}\text { solution times. The median value across a size range of } \\
20 \mathrm{~kW} \text { to } 2250 \mathrm{~kW} \text { and a load range of } 25 \% \text { to } 100 \% \text { was } \\
\text { selected as representative. }\end{array}$ \\
\hline $\begin{array}{l}\text { Fuel curve y- } \\
\text { intercept by } \\
\text { generator } \\
\text { capacity } \\
\text { (gal/hr) }\end{array}$ & 0 & $0-0.71$ & $\begin{array}{l}\text { Since a constant specific fuel consumption rate was } \\
\text { chosen as the default across generator sizes and load } \\
\text { conditions, the corresponding y-intercept value is assumed } \\
\text { to be 0. The input field is retained to allow for custom y- } \\
\text { intercept entries. }\end{array}$ \\
\hline
\end{tabular}

Table 28. Combined Heat and Power Inputs, Default Values, Ranges, and Sources

\begin{tabular}{|c|c|c|c|}
\hline Input & $\begin{array}{l}\text { Default } \\
\text { Value }\end{array}$ & Range & Source \\
\hline Size Class & & & See default/reference in Section 14.8 \& Appendix A \\
\hline $\begin{array}{l}\text { Electric power } \\
\text { capacity (kW) }\end{array}$ & & & See default/reference in Section 14.8 \& Appendix A \\
\hline $\begin{array}{l}\text { Install cost } \\
(\$ / k W)\end{array}$ & & & See default/reference in Section 14.8 \& Appendix A \\
\hline $\begin{array}{l}\text { Fixed O\&M } \\
\text { cost }(\$ / k W / y r)\end{array}$ & & & See default/reference in Section 14.8 \& Appendix A \\
\hline $\begin{array}{l}\text { Variable O\&M } \\
\text { cost (\$/kWh) }\end{array}$ & & & See default/reference in Section 14.8 \& Appendix A \\
\hline Incentives & $\begin{array}{l}10 \% \\
\text { ITC for } \\
\text { CHP } \\
5 \text { year } \\
\text { MACRS } \\
100 \% \\
\text { bonus } \\
\text { deprecia } \\
\text { tion }\end{array}$ & & $\begin{array}{l}\text { Database of State Incentives for Renewables \& } \\
\text { Efficiency. NC Clean Energy Tech Center, January } \\
2021 . \\
\text { http://www.dsireusa.org/ } \\
\text { http://programs.dsireusa.org/system/program/detail/658 } \\
\text { Incentives are available at the federal, state, and local } \\
\text { level. This site provides searchable specifics about } \\
\text { incentives based on location. The following federal } \\
\text { incentives are default values in REopt Lite: } \\
\text { Business Energy Investment Tax Credit. Database of } \\
\text { State Incentives for Renewables \& Efficiency, NC } \\
\text { Clean Energy Tech Center, January 2021. } \\
\text { http://programs.dsireusa.org/system/program/detail/658 } \\
\text { In } 2020, \text { a federal 10\% investment tax credit is available to } \\
\text { CHP projects. } \\
\text { Modified Accelerated Cost-Recovery System. } \\
\text { Database of State Incentives for Renewables \& } \\
\text { Efficiency, NC Clean Energy Tech Center, August } \\
2018 . \\
\text { http://programs.dsireusa.org/system/program/detail/676 } \\
\text { CHP projects are eligible for accelerated depreciation } \\
\text { deductions over a 5-year period, with bonus depreciation } \\
\text { of } 100 \% \text { in the first year. }\end{array}$ \\
\hline
\end{tabular}




\begin{tabular}{|c|c|c|c|}
\hline Input & $\begin{array}{l}\text { Default } \\
\text { Value }\end{array}$ & Range & Source \\
\hline $\begin{array}{l}\text { CHP } \\
\text { maintenance } \\
\text { schedule }\end{array}$ & & & See default/reference in Section 14.9 \\
\hline $\begin{array}{l}\text { Electric } \\
\text { efficiency at } \\
100 \% \text { load ( } \% \\
\text { HHV-basis) }\end{array}$ & & & See default/reference in Section 14.8 \& Appendix A \\
\hline $\begin{array}{l}\text { Electric } \\
\text { efficiency at } \\
50 \% \text { load (\% } \\
\text { HHV-basis) }\end{array}$ & & & See default/reference in Section 14.8 \\
\hline $\begin{array}{l}\text { Thermal } \\
\text { efficiency at } \\
100 \% \text { load ( } \% \\
\text { HHV-basis }\end{array}$ & & & See default/reference in Section 14.8 \& Appendix A \\
\hline $\begin{array}{l}\text { Thermal } \\
\text { efficiency at } \\
50 \% \text { load (\% } \\
\text { HHV-basis) }\end{array}$ & & & See default/reference in Section 14.8 \\
\hline $\begin{array}{l}\text { Min. electric } \\
\text { loading of } \\
\text { prime mover } \\
\text { (\% of rated } \\
\text { electric } \\
\text { capacity) }\end{array}$ & & & See default/reference in Section 14.8 \\
\hline $\begin{array}{l}\text { Knockdown } \\
\text { factor for } \\
\text { CHP-supplied } \\
\text { thermal to } \\
\text { Absorption } \\
\text { Chiller (\%) }\end{array}$ & & & See default/reference in Section 14.8 and Section 15 \\
\hline
\end{tabular}

Table 29. Hot Water Storage Inputs, Default Values, Ranges, and Sources

\begin{tabular}{|l|l|l|l|}
\hline Input & $\begin{array}{l}\text { Default } \\
\text { Value }\end{array}$ & Range & Source \\
\hline $\begin{array}{l}\text { Install cost } \\
\text { (\$/kW) }\end{array}$ & & See default/reference in Section 16 \\
\hline $\begin{array}{l}\text { Fixed O\&M } \\
\text { cost (\$/gal/yr) }\end{array}$ & & See default/reference in Section 16 \\
\hline $\begin{array}{l}\text { Thermal loss } \\
\text { rate, percent } \\
\text { of stored } \\
\text { energy (\%) }\end{array}$ & & See default/reference in Section 16 \\
\hline $\begin{array}{l}\text { Minimum } \\
\text { state of } \\
\text { charge (\%) }\end{array}$ & & See default/reference in Section 16 \\
\hline
\end{tabular}


Table 30. Absorption Chilling Inputs, Default Values, Ranges, and Sources

\begin{tabular}{|l|l|l|l|}
\hline Input & $\begin{array}{l}\text { Default } \\
\text { Value }\end{array}$ & Range & Source \\
\hline $\begin{array}{l}\text { Coefficient of } \\
\text { performance } \\
\text { (kWt/kWt) }\end{array}$ & & See default/reference in Section 15 \\
\hline $\begin{array}{l}\text { Electric } \\
\text { consumption } \\
\text { COP for heat } \\
\text { rejection } \\
\text { (kWt/kWe) }\end{array}$ & & See default/reference in Section 15 \\
\hline $\begin{array}{l}\text { Install cost } \\
\text { (\$/kW) }\end{array}$ & & See default/reference in Section 15 \\
\hline $\begin{array}{l}\text { Fixed O\&M } \\
\text { cost (\$/ton/yr) }\end{array}$ & & See default/reference in Section 15 \\
\hline
\end{tabular}

Table 31. Chilled Water Storage Inputs, Default Values, Ranges, and Sources

\begin{tabular}{|l|l|l|l|}
\hline Input & $\begin{array}{l}\text { Default } \\
\text { Value }\end{array}$ & Range & Source \\
\hline $\begin{array}{l}\text { Install cost } \\
\text { (\$/kW) }\end{array}$ & & See default/reference in Section 16 \\
\hline $\begin{array}{l}\text { Fixed O\&M } \\
\text { Cost (\$/gal/yr) }\end{array}$ & & See default/reference in Section 16 \\
\hline $\begin{array}{l}\text { Thermal loss } \\
\text { rate, percent } \\
\text { of stored } \\
\text { energy (\%) }\end{array}$ & See default/reference in Section 16 \\
\hline $\begin{array}{l}\text { Minimum } \\
\text { state of } \\
\text { charge (\%) }\end{array}$ & & See default/reference in Section 16 \\
\hline
\end{tabular}

\section{References}

ASHRAE. (2016). ASHRAE Handbook. HVAC Systems and Equipment. Chapter 51, Thermal Storage. ASHRAE.

ASHRAE. (2015). Combined Heat and Power Design Guide. ASHRAE.

Becker, W., Cutler, D., Anderson, K., \& Olis, D. (2019). REopt: Enabling Renewable Energy, Storage, and Combined Heat and Power. ACEEE Summer Study on Energy Efficiency in Industry. Portland, OR.

Cutler, D., Olis, D., Elgqvist, E., Li, X., Laws, N., Diorio, N., . . Anderson, K. (2017). REopt: A Platform for Energy System INtegration and Optimization. Golden: National Renewable Energy Laboratory.

Department of Energy Advanced Manufacturing Office. (2017). Absorption Chillers for CHP Systems (DOE CHP Technology Fact Sheet Series)- Fact Sheet, 2017. Retrieved from https://www.energy.gov/eere/amo/downloads/absorption-chillers-chp-systems-doe-chptechnology-fact-sheet-series-fact-sheet

Department of Energy Advanced Manufacturing Office. (2017). Combined Heat and Power Basics. Retrieved from Fact Sheets: https://www.energy.gov/eere/amo/combined-heatand-power-basics

Dobos, A. (2014). PVWatts version 5 manual. Golden: National Renewable Energy Laboratory. 
Dorgan, C. E., \& Elleson, J. S. (1993). Design guide for cool thermal storage. Atlanta: American Society of Heating, Refrigerating and Air-Conditioning Engineers.

Draxl, C., Hodge, B.-M., Clifton, A., \& McCaa, J. (2015). Overview and Meteorological Validation of the Wind Integration National Dataset Toolkit. Golden: National Renewable Energy Laboratory.

Fuller, S. K., \& Petersen, S. R. (1995). Life-Cycle Costing Manual for the Federal Energy Management Program. Boulder: National Insitute of Standards and Technology.

Glazer, J. (2019). Design Guide for Cool Thermal Storage, 2nd Edition. ASHRAE.

Hirwa, J. O. (2021). Optimizing Design and Dispatch of a Renewable Energy System with Combined Heat and Power. Submitted to: Optimization and Engineering.

Lantz, E., Sigrin, B., Gleason, M., Preus, R., \& Baring-Gould, I. (2016). Assessing the Future of Distributed Wind: Opportunities for Behind-the-Meter Projects. Golden: National Renewable Energy Laboratory.

Lawrence Berkeley National Laboratory. (2019). Combined Heat and Power eCatalog. Retrieved from https://chp.ecatalog.lbl.gov/

MacCraken, M. (2004). Thermal Energy Storage in Sustainable Buildings. ASHRAE Journal.

Ogunmodede, O. A. (2021). Optimizing Design and Dispatch of a Renewable Energy System. Accepted for Publication: Applied Energy.

Pacific Northwest National Laboratory. (2016). ANSI/ASHRAE/IES Standard 90.1-2010 Performance Rating Method Reference Manual, PNNL-25130. Richland: Pacific Northwest National Laboratory.

Rushing, A. S., Kneifel, J. D., \& Lippiatt, B. C. (2013). Energy Price Indices and Discount Factors for Life-Cycle Cost Analysis. Boulder: National Institute of Standards and Technology.

Short, W., Packey, D., \& Holt, T. (1995). A Manual for the Economic Evaluation of Energy Efficiency and Renewable Energy Technologies. Golden: National Renewable Energy Laboratory.

Sweetser, R. (2020, June). Exergy Partners Corporation. Personal Communication.

U.S. Environmental Protection Agency. (2015). Fuel and Carbon Dioxide Emissions Savings Calculation Methodology for Combined Heat and Power Systems. Washington, D.C.: U.S. Environmental Protection Agency.

U.S. Environmental Protection Agency. (2018, March). Emission Factors for Greenhouse Gas Inventories. Retrieved from https://www.epa.gov/sites/production/files/201803/documents/emission-factors_mar_2018_0.pdf

U.S. Environmental Protection Agency. (2019). AVoided Emissions and geneRation Tool (AVERT) User Manual, Version 2.3. Washington, D.C.: US Environmental Protection Agency.

U.S. Environmental Protection Agency. (2020, March 9). eGrid2018. Retrieved from Download Data: https://www.epa.gov/egrid/download-data 


\section{Appendix A: CHP Cost and Performance Data by Prime Mover Type and Size Class}

The cost and performance data in section 14.8, Default CHP Cost and Performance Parameters by Prime Mover Type and Size Class, was generated by averaging the available data within the size class range from the DOE CHP Fact Sheets (DOE Advanced Manufacturing Office 2017). The following tables show the raw data and highlights the data that was averaged to get the size class cost and performance parameters.

\begin{tabular}{|c|c|c|c|c|c|c|}
\hline \multirow{2}{*}{ Reciprocating Engine } & \multicolumn{6}{|c|}{ System } \\
\hline & 1 & 2 & 3 & 4 & 5 & 6 \\
\hline Net Electric Power (kW) & 35 & 100 & 633 & 1,141 & 3,325 & 9,341 \\
\hline Fuel Input (MMBtu/hr, HHV) & 0.40 & 1.15 & 6.26 & 10.50 & 27.74 & 75.82 \\
\hline Useful Thermal, Hot Water (MMBtu/hr) & 0.20 & 0.61 & 2.84 & 4.46 & 10.69 & 26.60 \\
\hline Cooling Thermal Factor (single effect) & $80 \%$ & $80 \%$ & $85 \%$ & $85 \%$ & $85 \%$ & $85 \%$ \\
\hline Electric Efficiency (\%, HHV) & $29.6 \%$ & $29.7 \%$ & $34.5 \%$ & $37.1 \%$ & $40.9 \%$ & $42.0 \%$ \\
\hline Hot Water Thermal Efficiency (\%, HHV) & $49.5 \%$ & $51.0 \%$ & $44.8 \%$ & $42.4 \%$ & $38.5 \%$ & $35.1 \%$ \\
\hline Steam Thermal Efficiency (\%, HHV) & $\mathrm{N} / \mathrm{A}$ & $\mathrm{N} / \mathrm{A}$ & $18.2 \%$ & $15.5 \%$ & $13.3 \%$ & $12.2 \%$ \\
\hline O\&M Cost (\$/kWh) & $\$ 0.025$ & $\$ 0.024$ & $\$ 0.021$ & $\$ 0.019$ & $\$ 0.016$ & $\$ 0.009$ \\
\hline Total Installed Cost $(\$ / \mathrm{kW})$ & $\$ 3,300$ & $\$ 2,900$ & $\$ 2,700$ & $\$ 2,370$ & $\$ 1,800$ & $\$ 1,430$ \\
\hline \multicolumn{7}{|l|}{ REopt Class 0} \\
\hline \multicolumn{7}{|l|}{ REopt Class 1} \\
\hline \multicolumn{7}{|l|}{ REopt Class 2} \\
\hline \multicolumn{7}{|l|}{ REopt Class 3} \\
\hline \multicolumn{7}{|l|}{ REopt Class 4} \\
\hline REopt Class 5 & & & & & & \\
\hline
\end{tabular}

\begin{tabular}{|c|c|c|c|c|c|c|}
\hline \multirow{2}{*}{ Microturbine } & \multicolumn{6}{|c|}{ System } \\
\hline & 1 & 2 & 3 & 4 & 5 & 6 \\
\hline Net Electric Power (kW) & 30 & 60 & 190 & 323 & 950 & 1,290 \\
\hline Fuel Input (MMBtu/hr, HHV) & 0.43 & 0.84 & 2.29 & 3.84 & 11.43 & 15.02 \\
\hline Useful Thermal, Hot Water (MMBtu/hr) & 0.21 & 0.39 & 0.90 & 1.45 & 4.30 & 5.65 \\
\hline Cooling Thermal Factor (single effect) & $94 \%$ & $94 \%$ & $94 \%$ & $94 \%$ & $94 \%$ & $94 \%$ \\
\hline Electric Efficiency (\%, HHV) & $23.6 \%$ & $24.4 \%$ & $28.3 \%$ & $28.7 \%$ & $28.4 \%$ & $29.3 \%$ \\
\hline Hot Water Thermal Efficiency (\%, HHV) & $48.5 \%$ & $46.2 \%$ & $39.3 \%$ & $37.8 \%$ & $37.6 \%$ & $37.6 \%$ \\
\hline Steam Thermal Efficiency (\%, HHV) & N/A & N/A & N/A & $\mathrm{N} / \mathrm{A}$ & $\mathrm{N} / \mathrm{A}$ & $\mathrm{N} / \mathrm{A}$ \\
\hline O\&M Cost (\$/kWh) & $\$ 0.026$ & $\$ 0.026$ & $\$ 0.016$ & $\$ 0.012$ & $\$ 0.012$ & $\$ 0.012$ \\
\hline Total Installed Cost $(\$ / \mathrm{kW})$ & $\$ 3,600$ & $\$ 3,220$ & $\$ 3,150$ & $\$ 2,580$ & $\$ 2,500$ & $\$ 2,400$ \\
\hline \multicolumn{7}{|l|}{ REopt Class 0} \\
\hline \multicolumn{7}{|l|}{ REopt Class 1} \\
\hline \multicolumn{7}{|l|}{ REopt Class 2} \\
\hline \multicolumn{7}{|l|}{ REopt Class 3} \\
\hline \multicolumn{7}{|l|}{ REopt Class 4} \\
\hline REopt Class 5 & & & & & & \\
\hline
\end{tabular}




\begin{tabular}{|c|c|c|c|c|c|c|c|}
\hline \multirow{2}{*}{ Combustion Turbine } & \multicolumn{7}{|c|}{ System } \\
\hline & $1(1)$ & 2 & 3 & 4 & 5 & 6 & 7 \\
\hline Net Electric Power (kW) & 950 & 1,825 & 3,304 & 5,400 & 7,487 & 14,100 & 20,440 \\
\hline Fuel Input (MMBtu/hr, HHV) & 15.4 & 27.6 & 47.5 & 68.2 & 87.6 & 160.4 & 210.8 \\
\hline Useful Thermal, Steam (MMBtu/hr) & 6.7 & 13.5 & 19.6 & 29.8 & 36.3 & 64.5 & 77.4 \\
\hline Cooling Thermal Factor (double effect) & $90 \%$ & $90 \%$ & $90 \%$ & $90 \%$ & $90 \%$ & $90 \%$ & $90 \%$ \\
\hline Electric Efficiency (\%, HHV) & $21.0 \%$ & $22.6 \%$ & $23.7 \%$ & $27.0 \%$ & $29.2 \%$ & $30.0 \%$ & $33.1 \%$ \\
\hline Steam Thermal Efficiency (\%, HHV) & $43.5 \%$ & $48.9 \%$ & $41.3 \%$ & $43.7 \%$ & $41.4 \%$ & $40.2 \%$ & $36.7 \%$ \\
\hline Hot Water Thermal Efficiency (\%, HHV) & $47.5 \%$ & $53.8 \%$ & $45.8 \%$ & $48.1 \%$ & $45.5 \%$ & $44.2 \%$ & $40.8 \%$ \\
\hline O\&M Cost (\$/kWh) & $\$ 0.015$ & $\$ 0.014$ & $\$ 0.013$ & $\$ 0.013$ & $\$ 0.012$ & $\$ 0.010$ & $\$ 0.009$ \\
\hline Total Installed Cost $(\$ / \mathrm{kW})$ & $\$ 4,480$ & $\$ 3,900$ & $\$ 3,320$ & $\$ 2,550$ & $\$ 2,017$ & $\$ 1,650$ & $\$ 1,474$ \\
\hline \multicolumn{8}{|l|}{ REopt Class 0} \\
\hline \multicolumn{8}{|l|}{ REopt Class 1} \\
\hline \multicolumn{8}{|l|}{ REopt Class 2} \\
\hline \multicolumn{8}{|l|}{ REopt Class 3} \\
\hline \multicolumn{8}{|l|}{ REopt Class 4} \\
\hline \multicolumn{8}{|l|}{ REopt Class 5} \\
\hline REopt Class 6 & & & & & & & \\
\hline
\end{tabular}




\section{Appendix B: Mathematical Formulation}

This section presents the mathematical formulation of REopt Lite $(\mathcal{R})$ from Ogunmodede et al. (2021) and Hirwa et al. (2021). We define, in alphabetic order within a group, indices and sets, parameters, and variables, in that order, and then state the objective function and the constraints. We choose as our naming convention calligraphic capital letters to represent sets, lower-case letters to represent parameters, and upper-case letters to represent variables; in the latter case, $Z$-variables are binary. $X$-variables represent continuous decisions, e.g., quantities of energy. All subscripts denote indices. Names with the same "stem" are related, and superscripts and "decorations" (e.g., hats, tildes) differentiate the names with respect to, e.g., various indices included in the name or maximum and minimum values for the same parameter.

\section{Sets and Parameters}

\begin{tabular}{|c|c|}
\hline \multicolumn{2}{|l|}{ Sets } \\
\hline $\mathcal{B}$ & Storage systems \\
\hline $\mathcal{C}$ & Technology classes \\
\hline $\mathcal{D}$ & Time-of-use demand periods \\
\hline $\mathcal{E}$ & Electrical time-of-use demand tiers \\
\hline $\mathcal{F}$ & Fuel types \\
\hline $\mathcal{H}$ & Time steps \\
\hline $\mathcal{K}$ & Subdivisions of power rating \\
\hline $\mathcal{M}$ & Months of the year \\
\hline $\mathcal{N}$ & Monthly peak demand tiers \\
\hline $\mathcal{S}$ & Power rating segments \\
\hline $\mathcal{T}$ & Technologies \\
\hline $\mathcal{U}$ & Total electrical energy pricing tiers \\
\hline $\mathcal{V}$ & Net metering regimes \\
\hline \multicolumn{2}{|c|}{ Subsets and Indexed Sets } \\
\hline $\mathcal{B}^{\mathrm{c}} \subseteq \mathcal{B}^{\text {th }}$ & Cold thermal energy storage systems \\
\hline $\mathcal{B}^{\mathrm{e}} \subseteq \mathcal{B}$ & Electrical storage systems \\
\hline $\mathcal{B}^{\mathrm{h}} \subseteq \mathcal{B}^{\text {th }}$ & Hot thermal energy storage systems \\
\hline $\mathcal{B}^{\text {th }} \subseteq \mathcal{B}$ & Thermal energy storage systems \\
\hline $\mathcal{H}^{\mathrm{g}} \subseteq \mathcal{H}$ & Time steps in which grid purchasing is available \\
\hline $\mathcal{H}_{m} \subseteq \mathcal{H}$ & Time steps within a given month $m$ \\
\hline $\mathcal{H}_{d} \subseteq \mathcal{H}$ & Time steps within electrical power time-of-use demand tier $d$ \\
\hline $\mathcal{K}_{t} \subseteq \mathcal{K}$ & Subdivisions applied to technology $t$ \\
\hline $\mathcal{K}^{\mathrm{c}} \subseteq \mathcal{K}$ & Capital cost subdivisions \\
\hline $\mathcal{M}^{\mathrm{lb}}$ & Look-back months considered for peak pricing \\
\hline $\mathcal{S}_{t k} \subseteq \mathcal{S}$ & Power rating segments from subdivision $k$ applied to technology $t$ \\
\hline $\mathcal{T}_{b} \subseteq \mathcal{T}$ & Technologies that can charge storage system $b$ \\
\hline $\mathcal{T}_{c} \subseteq \mathcal{T}$ & Technologies in class $c$ \\
\hline $\mathcal{T}_{f} \subseteq \mathcal{T}$ & Technologies that burn fuel type $f$ \\
\hline $\mathcal{T}_{u} \subseteq \mathcal{T}$ & Technologies that may access electrical energy sales pricing tier $u$ \\
\hline $\mathcal{T}_{v} \subseteq \mathcal{T}$ & Technologies that may access net-metering regime $v$ \\
\hline $\mathcal{T}^{\mathrm{ac}} \subseteq \mathcal{T}^{\mathrm{cl}}$ & Absorption chillers \\
\hline $\mathcal{T}^{\mathrm{CHP}} \subseteq \mathcal{T}^{\mathrm{f}}$ & CHP technologies \\
\hline $\mathcal{T}^{\mathrm{cl}} \subseteq \mathcal{T}$ & Cooling technologies \\
\hline $\mathcal{T}^{\mathrm{e}} \subseteq \mathcal{T}$ & Electricity-producing technologies \\
\hline $\mathcal{T}^{\mathrm{ec}} \subseteq \mathcal{T}^{\mathrm{cl}}$ & Electric chillers \\
\hline $\mathcal{T}^{\mathrm{f}} \subseteq \mathcal{T}^{\mathrm{e}}$ & Fuel-burning, electricity-producing technologies \\
\hline $\mathcal{T}^{\text {ht }} \subseteq \mathcal{T}$ & Heating technologies \\
\hline
\end{tabular}


$\mathcal{T}^{\text {td }} \subseteq \mathcal{T} \quad$ Technologies that cannot turn down, i.e., PV and wind

$\mathcal{U}^{\mathrm{c}} \subseteq \mathcal{U}^{\mathrm{s}} \quad$ Electrical energy curtailment pricing tiers

$\mathcal{U}^{\mathrm{nm}} \subseteq \mathcal{U}^{s} \quad$ Electrical energy sales pricing tiers used in net metering

$\mathcal{U}^{\mathrm{p}} \subseteq \mathcal{U} \quad$ Electrical energy purchase pricing tiers

$\mathcal{U}^{\mathrm{s}} \subseteq \mathcal{U} \quad$ Electrical energy sales pricing tiers

$\mathcal{U}_{t}^{\mathrm{s}} \subseteq \mathcal{U}^{\mathrm{s}} \quad$ Electrical energy sales pricing tiers accessible by technology $t$

$\mathcal{U}^{\text {sb }} \subseteq \mathcal{U}^{\mathrm{s}} \quad$ Electrical energy sales pricing tiers accessible by storage

\section{Scaling Parameters}

$\begin{array}{lll}\Gamma & \text { Number of time periods within a day } & {[-]} \\ \Delta & \text { Time step scaling } & {[\mathrm{h}]} \\ \Theta & \text { Peak load oversizing factor } & {[-]} \\ M & \text { Sufficiently large number } & \text { [various] }\end{array}$

Parameters for Costs and their Functional Forms

$\begin{array}{lll}c^{\mathrm{afc}} & \text { Utility annual fixed charge } & {[\$]} \\ c^{\mathrm{amc}} & \text { Utility annual minimum charge } & {[\$]} \\ c_{t s}^{\mathrm{cb}} & y \text {-intercept of capital cost curve for technology } t \text { in segment } s & {[\$]} \\ c_{t s}^{\mathrm{cm}} & \text { Slope of capital cost curve for technology } t \text { in segment } s & {[\$ / \mathrm{kW}]} \\ c_{u h}^{\mathrm{e}} & \text { Export rate for energy in energy demand tier } u \text { in time step } h & {[\$ / \mathrm{kWh}]} \\ c_{u h}^{\mathrm{g}} & \text { Grid energy cost in energy demand tier } u \text { during time step } h & {[\$ / \mathrm{kWh}]} \\ c_{b}^{\mathrm{kW}} & \text { Capital cost of power capacity for storage system } b & {[\$ / \mathrm{kW}]} \\ c_{b}^{\mathrm{kWh}} & \text { Capital cost of energy capacity for storage system } b & {[\$ / \mathrm{kWh}]} \\ c_{b}^{\mathrm{omb}} & \text { Operation and maintenance cost of storage system } b \text { per unit of energy rating } & {[\$ / \mathrm{kWh}]} \\ c_{t}^{\mathrm{bmp}} & \text { Operation and maintenance cost of technology } t \text { per unit of production } & {[\$ / \mathrm{kWh}]} \\ c_{t}^{\mathrm{om} \sigma} & \text { Operation and maintenance cost of technology } t \text { per unit of power rating, } & {[\$ / \mathrm{kW}]} \\ & \text { including standby charges } & \\ c_{d e}^{\mathrm{r}} & \text { Cost per unit peak demand in time-of-use demand period } d \text { and tier } e & {[\$ / \mathrm{kW}]} \\ c_{m n}^{\mathrm{rm}} & \text { Cost per unit peak demand in tier } n \text { during month } m & {[\$ / \mathrm{kW}]} \\ c_{f}^{\mathrm{un}} & \text { Unit cost of fuel type } f & {[\$ / \mathrm{MMBTU}]}\end{array}$

\section{Demand Parameters}

$\begin{array}{lll}\delta_{h}^{\mathrm{c}} & \text { Cooling load in time step } h & {[\mathrm{~kW}]} \\ \delta_{h}^{\mathrm{d}} & \text { Electrical load in time step } h & {[\mathrm{~kW}]} \\ \bar{\delta}_{u}^{\mathrm{gs}} & \text { Maximum allowable sales in electrical energy demand tier } u & {[\mathrm{kWh}]} \\ \delta_{h}^{\mathrm{h}} & \text { Heating load in time step } h & {[\mathrm{~kW}]} \\ \delta^{\mathrm{lp}} & \text { Look-back proportion for ratchet charges } & {[\mathrm{fraction}]} \\ \bar{\delta}_{n}^{\mathrm{mt}} & \text { Maximum monthly electrical power demand in peak pricing tier } n & {[\mathrm{~kW}]} \\ \bar{\delta}_{e}^{\mathrm{t}} & \text { Maximum power demand in time-of-use demand tier } e & {[\mathrm{~kW}]} \\ \bar{\delta}_{u}^{\mathrm{tu}} & \text { Maximum monthly electrical energy demand in tier } u & {[\mathrm{kWh}]}\end{array}$

Incentive Parameters

\begin{tabular}{lll}
$\bar{\imath}_{t}$ & Upper incentive limit for technology $t$ & {$[\$]$} \\
$i_{v}^{\mathrm{n}}$ & Net metering limits in net metering regime $v$ & {$[\mathrm{~kW}]$} \\
$i_{t}^{\mathrm{r}}$ & Incentive rate for technology $t$ & {$[\$ / \mathrm{kWh}]$} \\
$\bar{\imath}_{t}^{\sigma}$ & Maximum power rating for obtaining production incentive for technology $t$ & {$[\mathrm{~kW}]$} \\
& & \\
& & \\
\hline echnology-Specific Time-Series Factor Parameters & {$[$ unitless] } \\
$f_{t h}^{\text {ed }}$ & Electrical power de-rate factor of technology $t$ at time step $h$ & {$[\mathrm{unitless}]$} \\
$f_{t h}^{\mathrm{fa}}$ & Fuel burn ambient correction factor of technology $t$ at time step $h$ & {$[\mathrm{unitless}]$} \\
$f_{t h}^{\mathrm{hh}}$ & Hot water ambient correction factor of technology $t$ at time step $h$ & {$[$ unitless] } \\
$f_{t h}^{\text {ht }}$ & Hot water thermal grade correction factor of technology $t$ at time step $h$ &
\end{tabular}


$f_{t h}^{\mathrm{p}} \quad$ Production factor of technology $t$ during time step $h \quad$ [unitless]

Technology-Specific Factor Parameters

$\begin{array}{lll}f_{t}^{\mathrm{d}} & \text { Derate factor for turbine technology } t & \text { [unitless] } \\ f_{t}^{\mathrm{l}} & \text { Levelization factor of technology } t & \text { [fraction] } \\ f_{t}^{\mathrm{li}} & \text { Levelization factor of production incentive for technology } t & \text { [fraction] } \\ f_{t}^{\mathrm{pf}} & \text { Present worth factor for fuel for technology } t & \text { [unitless] } \\ f_{t}^{\mathrm{pi}} & \text { Present worth factor for incentives for technology } t & \text { [unitless] } \\ \underline{f}_{t}^{\mathrm{td}} & \text { Minimum turn down for technology } t & \text { [unitless] }\end{array}$

Generic Factor Parameters

$\begin{array}{lll}f^{\mathrm{e}} & \text { Energy present worth factor } & \text { [unitless] } \\ f^{\text {om }} & \text { Operations and maintenance present worth factor } & \text { [unitless] } \\ f^{\text {tot }} & \text { Tax rate factor for off-taker } & \text { [fraction] } \\ f^{\text {tow }} & \text { Tax rate factor for owner } & \text { [fraction] }\end{array}$

Power Rating and Fuel Limit Parameters

$\begin{array}{lll}b_{f}^{\mathrm{fa}} & \text { Amount of available fuel for fuel type } f & {[\mathrm{MMBTU}]} \\ \underline{b}_{c}^{\sigma} & \text { Minimum power rating for technology class } c & {[\mathrm{~kW}]} \\ \bar{b}_{t}^{\sigma} & \text { Maximum power rating for technology } t & {[\mathrm{~kW}]} \\ \underline{b}_{t k s}^{\sigma \mathrm{s}} & \text { Minimum power rating for technology } t, \text { subdivision } k, \text { segment } s & {[\mathrm{~kW}]} \\ \bar{b}_{t k s}^{\sigma \mathrm{s}} & \text { Maximum power rating for technology } t \text {, subdivision } k, \text { segment } s & {[\mathrm{~kW}]}\end{array}$

\section{Efficiency Parameters}

$\begin{array}{lll}\eta_{b t}^{+} & \text {Efficiency of charging storage system } b \text { using technology } t & \text { [fraction] } \\ \eta_{b}^{-} & \text {Efficiency of discharging storage system } b & \text { [fraction] } \\ \eta^{\text {ac }} & \text { Absorption chiller efficiency } & \text { [fraction] } \\ \eta^{\mathrm{b}} & \text { Boiler efficiency } & \text { [fraction] } \\ \$ \eta^{\mathrm{ec}} & \text { Electric chiller efficiency } & \text { [fraction] } \\ \eta^{\mathrm{g}+} & \text { Efficiency of charging electrical storage using grid power } & \text { [fraction] }\end{array}$

\section{Storage Parameters}

$\begin{array}{lll}\bar{w}_{b}^{b \mathrm{~kW}} & \text { Maximum power output of storage system } b & {[\mathrm{~kW}]} \\ \underline{w}_{b}^{\mathrm{bkW}} & \text { Minimum power output of storage system } b & {[\mathrm{~kW}]} \\ \bar{w}_{b}^{\mathrm{bkWh}} & \text { Maximum energy capacity of storage system } b & {[\mathrm{kWh}]} \\ \underline{w}_{b}^{\mathrm{bkWh}} & \text { Minimum energy capacity of storage system } b & {[\mathrm{kWh}]} \\ w_{b}^{\mathrm{d}} & \text { Decay rate of storage system } b & {[1 / \mathrm{h}]} \\ \underline{w}_{b}^{\mathrm{mcp}} & \text { Minimum percent state of charge of storage system } b & {[\mathrm{fraction}]} \\ w_{b}^{0} & \text { Initial percent state of charge of storage system } b & \text { [fraction] }\end{array}$

Fuel Burn Parameters

\begin{tabular}{lll}
$m_{t}^{\mathrm{fb}}$ & $y$-intercept of the fuel rate curve for technology $t$ & {$[\mathrm{MMBTU} / \mathrm{h}]$} \\
$m_{t}^{\mathrm{fbm}}$ & Fuel burn rate $y$-intercept per unit size for technology $t$ & {$[\mathrm{MMBTU} / \mathrm{kWh}]$} \\
$m_{t}^{\mathrm{fm}}$ & Slope of the fuel rate curve for technology $t$ & \\
& & \\
& & \\
CHP Thermal Performance Parameters & [MMUU/kWh] \\
\hline$k_{t}^{\mathrm{te}}$ & Thermal energy production of CHP technology $t$ per unit electrical output & [unitless] \\
$k_{t}^{\mathrm{tp}}$ & Thermal power production of CHP technology $t$ per unit power rating & [unitless]
\end{tabular}

\section{Variables}


Boundary Conditions

$X_{b, 0}^{\text {se }} \quad$ Initial state of charge for storage system $b$

$[\mathrm{kWh}]$

Continuous Variables

$X_{b}^{\mathrm{bkW}} \quad$ Power rating for storage system $b$

$X_{b}^{\mathrm{bkWh}} \quad$ Energy rating for storage system $b$

$[\mathrm{kW}]$

$X_{d e}^{\text {de }} \quad$ Peak electrical power demand allocated to tier $e$ and time-of-use demand period $d$

$X_{b h}^{\text {dfs }} \quad$ Power discharged from storage system $b$ during time step $h$

$X_{m n}^{\mathrm{dn}} \quad$ Peak electrical power demand allocated to tier $n$ during month $m$

Fuel burned by technology $t$ in time step $h$

$X_{t h}^{\mathrm{f}}$

$X_{t h}^{\mathrm{fb}}$

$y$-intercept of fuel burned by technology $t$ in time step $h$

$X_{u h}^{\mathrm{g}} \quad$ Power purchased from the grid for electrical load in demand tier $u$

during time step $h$

$[\mathrm{kWh}]$

$[\mathrm{kW}]$

$[\mathrm{kW}]$

$[\mathrm{kW}]$

$[\mathrm{MMBTU} / \mathrm{h}]$

$[\mathrm{MMBTU} / \mathrm{h}]$

$X_{h}^{\text {gts }} \quad$ Electrical power delivered to storage by the grid in time step $h$

$[\mathrm{kW}]$

$[\mathrm{kW}]$

$X^{\mathrm{mc}} \quad$ Annual utility minimum charge adder

$[\$]$

$X_{t}^{\mathrm{pi}} \quad$ Production incentive collected for technology $t$

$[\$]$

$X^{\text {plb }} \quad$ Peak electrical demand during look back periods

$X_{t u h}^{\mathrm{ptg}} \quad$ Exports from production to the grid by technology $t$ in demand tier $u$ during time step $h$

$[\mathrm{kW}]$

$X_{b t h}^{\mathrm{pts}}$

Power from technology $t$ used to charge storage system $b$ during time step $h$

$[\mathrm{kW}]$

Thermal power from technology $t$ sent to waste or curtailed during time step $h$

$[\mathrm{kW}]$

$X_{t h}^{\mathrm{p} w}$

Rated production of technology $t$ during time step $h$

$[\mathrm{kW}]$

$[\mathrm{kW}]$

$X_{t}^{\sigma} \quad$ Power rating of technology $t$

$X_{t k s}^{\sigma \mathrm{s}}$

Power rating of technology $t$ allocated to subdivision $k$, segment $s$
State of charge of storage system $b$ at the end of time step $h$

$X_{b h}^{\text {se }}$

$[\mathrm{kW}]$

$X_{u h}^{\text {stg }}$

Exports from storage to the grid in demand tier $u$ during time step $h$

$[\mathrm{kWh}]$

$X_{t h}^{\mathrm{tp}}$

Thermal production of technology $t$ in time step $h$

$[\mathrm{kW}]$

$X_{t h}^{\mathrm{tpb}}$

$y$-intercept of thermal production of CHP technology $t$ in time step $h$

Binary Variables

$Z_{m n}^{\text {dmt }} \quad 1$ If tier $n$ has allocated demand during month $m ; 0$ otherwise

$Z_{d e}^{\mathrm{dt}} \quad 1$ if tier $e$ has allocated demand during time-of-use period $d ; 0$ otherwise

$Z_{v}^{\text {nmil }} \quad 1$ If generation is in net metering interconnect limit regime $v$; 0 otherwise

$Z_{t}^{\mathrm{pi}} \quad 1$ If production incentive is available for technology $t$; 0 otherwise

$Z_{t k s}^{\sigma \mathrm{s}} \quad 1$ If technology $t$ in subdivision $k$, segment $s$ is chosen; 0 otherwise

$Z_{\text {to }}^{\text {to }} \quad 1$ If technology $t$ is operating in time step $h$; 0 otherwise

$Z_{m u}^{\mathrm{ut}} \quad 1$ If demand tier $u$ is active in month $m$; 0 otherwise

$[\mathrm{kW}]$

$[\mathrm{kW}]$

[unitless]

[unitless]

[unitless]

[unitless]

[unitless]

[unitless]

[unitless] 


\section{Objective Function}

$$
\begin{aligned}
& (\widehat{\mathcal{R}}) \text { minimize } \underbrace{\sum_{t \in \mathcal{T}, k \in \mathcal{K}^{\mathrm{c}}, s \in \mathcal{S}_{t k}}\left(c_{t s}^{\mathrm{cm}} \cdot X_{t k s}^{\sigma \mathrm{s}}+c_{t s}^{\mathrm{cb}} \cdot Z_{t k s}^{\sigma \mathrm{s}}\right)}_{\text {Generating Technology Capital Costs }}+ \\
& \underbrace{\sum_{b \in \mathcal{B}}\left(c_{b}^{\mathrm{kW}} \cdot X_{b}^{\mathrm{bkW}}+\left(c_{b}^{\mathrm{kWh}}+c_{b}^{\mathrm{omb}}\right) \cdot X_{b}^{\mathrm{bkWh}}\right)}_{\text {Storage Capital Costs }}+ \\
& \left(1-f^{\mathrm{tow}}\right) \cdot f^{\mathrm{om}} \cdot(\underbrace{\sum_{t \in \mathcal{T}} c_{t}^{\mathrm{om} \sigma} \cdot X_{t}^{\sigma}}_{\text {Fixed O\&M Costs }}+\underbrace{\sum_{t \in \mathcal{T}_{\mathrm{f}}, h \in \mathcal{H}} c_{t}^{\mathrm{omp}} \cdot X_{t h}^{\mathrm{rp}}}_{\text {Variable O\&M Costs }})+ \\
& \left(1-f^{\mathrm{tot}}\right) \cdot \underbrace{\Delta \cdot \sum_{f \in \mathcal{F}} c_{f}^{\mathrm{u}} \cdot \sum_{t \in \mathcal{T}_{f}, h \in \mathcal{H}} f_{t}^{\mathrm{pf}} \cdot X_{t h}^{\mathrm{f}}}_{\text {Fuel Charges }}+ \\
& \left(1-f^{\text {tot }}\right) \cdot f^{\mathrm{e}} \cdot(\underbrace{\Delta \cdot \sum_{u \in \mathcal{U}^{\mathrm{p}}, h \in \mathcal{H}^{\mathrm{g}}} c_{u h}^{\mathrm{g}} \cdot X_{u h}^{\mathrm{g}}}_{\text {Grid Energy Charges }}+ \\
& \underbrace{\sum_{d \in \mathcal{D}, e \in \mathcal{E}} c_{d e}^{\mathrm{r}} \cdot X_{d e}^{\mathrm{de}}}_{\text {e-of-Use Demand Charges }}+\underbrace{\sum_{m \in \mathcal{M}, n \in \mathcal{N}} c_{m n}^{\mathrm{rm}} \cdot X_{m n}^{\mathrm{dn}}}_{\text {Monthly Demand Charges }}+ \\
& \underbrace{c^{\text {afc }}+X^{\mathrm{mc}}}_{\text {Fixed Charges }}- \\
& \left.\Delta \cdot\left(\sum_{h \in \mathcal{H}^{\mathrm{g}}}\left(\sum_{u \in \mathcal{U}^{\mathrm{sb}}} c_{u h}^{\mathrm{e}} \cdot X_{u h}^{\mathrm{stg}}+\sum_{t \in \mathcal{T}, u \in \mathcal{U}_{t}^{\mathrm{s}}} c_{u h}^{\mathrm{e}} \cdot X_{t u h}^{\mathrm{ptg}}\right)\right)\right)- \\
& \text { Energy Export Payment } \\
& \left(1-f^{\text {tow }}\right) \cdot \underbrace{\sum_{t \in \mathcal{T}} X_{t}^{\mathrm{pi}}}_{\text {Production Incentives }}
\end{aligned}
$$

The objective function minimizes energy life cycle cost, i.e., capital costs, O\&M costs, and utility costs; it maximizes (by subtracting) payments for energy exports and other incentives.

\section{Constraints}

4.1. Fuel constraints

$$
\begin{aligned}
& \Delta \cdot \sum_{t \in \mathcal{T}_{f}, h \in \mathcal{H}} X_{t h}^{\mathrm{f}} \leq b_{f}^{\mathrm{fa}} \quad \forall f \in \mathcal{F} \\
& X_{t h}^{\mathrm{f}}=m_{t}^{\mathrm{fm}} \cdot f_{t h}^{\mathrm{p}} \cdot X_{t h}^{\mathrm{rp}}+m_{t}^{\mathrm{fb}} \cdot Z_{t h}^{\mathrm{to}} \quad \forall t \in \mathcal{T}^{\mathrm{f}} \backslash \mathcal{T}^{\mathrm{CHP}}, h \in \mathcal{H} \\
& X_{t h}^{\mathrm{f}}=m_{t}^{\mathrm{fm}} \cdot X_{t h}^{\mathrm{tp}} \quad \forall t \in \mathcal{T}^{\mathrm{ht}} \backslash \mathcal{T}^{C H P}, h \in \mathcal{H}
\end{aligned}
$$




$$
\begin{aligned}
& X_{t h}^{\mathrm{f}}=f_{t h}^{\mathrm{fa}} \cdot\left(X_{t h}^{\mathrm{fb}}+f_{t h}^{\mathrm{p}} \cdot m_{t}^{\mathrm{fm}} \cdot X_{t h}^{\mathrm{rp}}\right) \quad \forall t \in \mathcal{T}^{C H P}, h \in \mathcal{H} \\
& m_{t}^{\mathrm{fbm}} \cdot X_{t}^{\sigma}-M \cdot\left(1-Z_{t h}^{\mathrm{to}}\right) \leq X_{t h}^{\mathrm{fb}} \quad \forall t \in \mathcal{T}^{\mathrm{CHP}}, h \in \mathcal{H}
\end{aligned}
$$

Constraint (1a) limits fuel consumption for each fuel type, which can be burned by different technologies. Constraint (1b) uses a linear function to relate a non-CHP, fuel-burning electricity-producing technology's output to the corresponding consumption. Constraint (1c) defines the fuel burn of each non-CHP heating technology as directly proportional to its thermal production in each hour. Constraint (1d) defines fuel consumption using a size-dependent $y$-intercept and fixed slope, for every CHP technology and hour. Constraint (1e) limits the $y$-intercept of fuel burned by a CHP technology in a given time step based on the power rating of the technology as long as the technology is operating, and is void otherwise.

\subsection{Thermal production constraints}

$$
\begin{array}{rr}
X_{t h}^{\mathrm{tpb}} \leq \min \left\{k_{t}^{\mathrm{tp}} \cdot X_{t}^{\sigma}, M \cdot Z_{t h}^{\mathrm{to}}\right\} & \forall t \in \mathcal{T}^{\mathrm{CHP}}, h \in \mathcal{H} \\
X_{t h}^{\mathrm{tpb}} \geq k_{t}^{\mathrm{tp}} \cdot X_{t}^{\sigma}-M \cdot\left(1-Z_{t h}^{\mathrm{to}}\right) & \forall t \in \mathcal{T}^{\mathrm{CHP}}, h \in \mathcal{H} \\
f_{t h}^{\mathrm{ha}} \cdot f_{t h}^{\mathrm{ht}} \cdot\left(k_{t}^{\mathrm{te}} \cdot f_{t h}^{\mathrm{p}} \cdot X_{t h}^{\mathrm{rp}}+X_{t h}^{\mathrm{tpb}}\right)=X_{t h}^{\mathrm{tp}} & \forall t \in \mathcal{T}^{\mathrm{CHP}}, h \in \mathcal{H}
\end{array}
$$

Constraints (2a)-(2b) limit the fixed component of thermal production of CHP technology $t$ in time step $h$ to the product of the thermal power production per unit of power rating and the power rating itself if the technology is operating, and 0 if it is not. Constraint (2c) relates the thermal production of a CHP technology to its constituent components, where the relationship includes a term that is proportional to electrical power production in each time step.

\subsection{Storage System Constraints}

Boundary Conditions and Size Limits

$$
\begin{aligned}
& X_{b, 0}^{\mathrm{se}}=w_{b}^{0} \cdot X_{b}^{\mathrm{bkWh}} \quad \forall b \in \mathcal{B} \\
& \underline{w}_{b}^{\mathrm{bkWh}} \leq X_{b}^{\mathrm{bkWh}} \leq \bar{w}_{b}^{\mathrm{bkWh}} \quad \forall b \in \mathcal{B} \\
& \underline{w}_{b}^{\mathrm{bkW}} \leq X_{b}^{\mathrm{bkW}} \leq \bar{w}_{b}^{\mathrm{bkW}} \quad \forall b \in \mathcal{B}
\end{aligned}
$$

Constraint (3a) initializes a storage system's state of charge using a fraction of its energy rating; constraints (3b) - (3c) limit the storage system size under the implicit assumption that a storage system's power and energy ratings are independent. These constraints are identical to those given in $(\mathcal{R})$, but work in conjunction with significantly modified storage constraints that directly follow.

Storage Operations

$$
\begin{aligned}
& X_{b t h}^{\mathrm{pts}}+\sum_{u \in \mathcal{U}_{t}^{\mathrm{s}}} X_{t u h}^{\mathrm{ptg}} \leq f_{t h}^{\mathrm{p}} \cdot f_{t}^{\mathrm{l}} \cdot X_{t h}^{\mathrm{rp}} \quad \forall b \in \mathcal{B}^{\mathrm{e}}, t \in \mathcal{T}^{\mathrm{e}}, h \in \mathcal{H}^{\mathrm{g}} \\
& X_{b t h}^{\mathrm{pts}} \leq f_{t h}^{\mathrm{p}} \cdot f_{t}^{\mathrm{l}} \cdot X_{t h}^{\mathrm{rp}} \quad \forall b \in \mathcal{B}^{\mathrm{e}}, t \in \mathcal{T}^{\mathrm{e}}, h \in \mathcal{H} \backslash \mathcal{H}^{\mathrm{g}} \\
& X_{b t h}^{\mathrm{pts}} \leq f_{t h}^{\mathrm{p}} \cdot X_{t h}^{\mathrm{tp}} \quad \forall b \in \mathcal{B}^{\mathrm{th}}, t \in \mathcal{T}_{b} \backslash \mathcal{T}^{\mathrm{CHP}}, h \in \mathcal{H} \\
& X_{b t h}^{\mathrm{pts}}+X_{t h}^{\mathrm{ptw}} \leq X_{t h}^{\mathrm{tp}} \quad \forall b \in \mathcal{B}^{\mathrm{h}}, t \in \mathcal{T}^{\mathrm{CHP}}, h \in \mathcal{H} \\
& X_{b h}^{\mathrm{se}}=X_{b, h-1}^{\mathrm{se}}+\Delta \cdot\left(\sum_{t \in \mathcal{T}^{\mathrm{e}}}\left(\eta_{b t}^{+} \cdot X_{b t h}^{\mathrm{pts}}\right)+\eta^{\mathrm{g}+} \cdot X_{h}^{\mathrm{gts}}-X_{b h}^{\mathrm{dfs}} / \eta_{b}^{-}\right) \\
& \forall b \in \mathcal{B}^{\mathrm{e}}, h \in \mathcal{H}^{\mathrm{g}}
\end{aligned}
$$




$$
\begin{aligned}
& X_{b h}^{\mathrm{se}}=X_{b, h-1}^{\mathrm{se}}+\Delta \cdot\left(\sum_{t \in \mathcal{T}^{\mathrm{e}}}\left(\eta_{b t}^{+} \cdot X_{b t h}^{\mathrm{pts}}\right)-X_{b h}^{\mathrm{dfs}} / \eta_{b}^{-}\right) \\
& \forall b \in \mathcal{B}^{\mathrm{e}}, h \in \mathcal{H} \backslash \mathcal{H}^{\mathrm{g}} \\
& X_{b h}^{\mathrm{se}}=X_{b, h-1}^{\mathrm{se}}+\Delta \cdot\left(\sum_{t \in \mathcal{T}_{b}} \eta_{b t}^{+} \cdot X_{b t h}^{\mathrm{pts}}-X_{b h}^{\mathrm{dfs}} / \eta_{b}^{-}-w_{b}^{\mathrm{d}} \cdot X_{b h}^{\mathrm{se}}\right) \\
& X_{b h}^{\mathrm{se}} \geq \underline{w}_{b}^{\mathrm{mcp}} \cdot X_{b}^{\mathrm{bkWh}} \quad \forall b \in \mathcal{B}, h \in \mathcal{H} \\
& \forall b \in \mathcal{B}^{\mathrm{th}}, h \in \mathcal{H}
\end{aligned}
$$

Constraints (3d) and (3e) restrict the electrical power that charges storage and is exported to the grid (in the former case), or that charges storage only (in the latter case, when grid export is unavailable) from each technology in each time step relative to the amount of electricity produced. Constraint (3f) provides an analogous restriction to that of constraint (3e) for thermal production, and constraint (3g) provides the same restriction for the thermal production of CHP systems. Constraints (3h), (3i), and (3j) balance state-of-charge for each storage system and time period for three specific cases, respectively: (i) available grid-purchased electricity, (ii) lack of grid-purchased electricity, and (iii) thermal storage, in which we account for decay. Constraint (3k) ensures that minimum state of charge requirements are not violated.

\section{Charging Rates}

$$
\begin{aligned}
& X_{b}^{\mathrm{bkW}} \geq \sum_{t \in \mathcal{T}_{b}} X_{b t h}^{\mathrm{pts}}+X_{h}^{\mathrm{gts}}+X_{b h}^{\mathrm{dfs}} \quad \forall b \in \mathcal{B}^{\mathrm{e}}, h \in \mathcal{H}^{\mathrm{g}} \\
& X_{b}^{\mathrm{bkW}} \geq \sum_{t \in \mathcal{T}_{b}} X_{b t h}^{\mathrm{pts}}+X_{b h}^{\mathrm{dfs}} \quad \forall b \in \mathcal{B}^{\mathrm{e}}, h \in \mathcal{H} \backslash \mathcal{H}^{\mathrm{g}} \\
& X_{b}^{\mathrm{bkW}} \geq \sum_{t \in \mathcal{T}_{b}} X_{b t h}^{\mathrm{pts}}+X_{b h}^{\mathrm{dfs}} \quad \forall b \in \mathcal{B}^{\mathrm{th}}, h \in \mathcal{H} \\
& X_{b h}^{\mathrm{se}} \leq X_{b}^{\mathrm{bkWh}} \quad \forall b \in \mathcal{B}, h \in \mathcal{H}
\end{aligned}
$$

Constraints (3l) and (3m) require that power available must meet or exceed that put into or discharged from storage; the latter constraint considers the case in which the grid is not available. Constraint (3n) reflects the power requirements for the thermal system. Constraint (3o) requires a storage system's energy level to be at or below the corresponding rating.

Cold and hot thermal loads

$$
\begin{aligned}
\sum_{t \in \mathcal{T}^{c l}} f_{t h}^{\mathrm{p}} \cdot X_{t h}^{\mathrm{tp}}+\sum_{b \in \mathcal{B}^{c}} X_{b h}^{\mathrm{dfs}}=\delta_{h}^{\mathrm{c}} \cdot \eta^{\mathrm{ec}}+\sum_{b \in \mathcal{B}^{\mathrm{c}}, t \in \mathcal{T}^{\mathrm{cl}}} X_{b t h}^{\mathrm{pts}} \quad \forall h \in \mathcal{H} \\
\sum_{t \in \mathcal{T}^{\mathrm{CHP}}} X_{t h}^{\mathrm{tp}}+\sum_{t \in \mathcal{T}^{\mathrm{ht}} \backslash \mathcal{T}^{\mathrm{CHP}}} f_{t h}^{\mathrm{p}} \cdot X_{t h}^{\mathrm{tp}}+\sum_{b \in \mathcal{B}^{\mathrm{h}}} X_{b h}^{\mathrm{dfs}}=\delta_{h}^{\mathrm{h}} \cdot \eta^{\mathrm{b}} \\
\quad+\sum_{t \in \mathcal{T}^{\mathrm{CHP}}} X_{t h}^{\mathrm{ptw}}+\sum_{b \in \mathcal{B}^{\mathrm{h}}, t \in \mathcal{T}^{\mathrm{ht}}} X_{b t h}^{\mathrm{pts}}+\sum_{t \in \mathcal{T}^{\mathrm{ac}}} X_{t h}^{\mathrm{tp}} / \eta^{\mathrm{ac}} \quad \forall h \in \mathcal{H}
\end{aligned}
$$

Constraints (4a) and (4b) balance cold and hot thermal loads, respectively, by equating the power production and the power from storage with the sum of the demand, the power to storage, and, in the case of cold loads, from the absorption chillers as well. Here, for legacy reasons, we have scaled the power by the efficiency of the respective technology; based on our variable definitions, we could have equivalently adjusted these by a coefficient of performance. 


\subsection{Production Constraints}

$$
\begin{aligned}
& X_{t h}^{\mathrm{rp}} \leq \bar{b}_{t}^{\sigma} \cdot Z_{t h}^{\mathrm{to}} \quad \forall t \in \mathcal{T}, h \in \mathcal{H} \\
& \underline{f}_{t}^{\mathrm{td}} \cdot X_{t}^{\sigma}-X_{t h}^{\mathrm{rp}} \leq \bar{b}_{t}^{\sigma} \cdot\left(1-Z_{t h}^{\mathrm{to}}\right) \quad \forall t \in \mathcal{T}, h \in \mathcal{H} \\
& X_{t h}^{\mathrm{tp}} \leq X_{t}^{\sigma} \quad \forall t \in \mathcal{T} \backslash \mathcal{T}^{\mathrm{e}}, h \in \mathcal{H}
\end{aligned}
$$

Constraint set (5) ensures that the rated production lies between a minimum turn-down threshold and a maximum system size. Constraint (5a) restricts system power output to its rated capacity when the technology is operating, and to 0 otherwise. Constraint (5b) ensures a minimum power output while a technology is operating; otherwise, the constraint is dominated by simple bounds on production. Constraint (5c) ensures that the thermal production of non-CHP heating and cooling technologies does not exceed system size.

\subsection{Production Incentives}

$$
\begin{aligned}
& X_{t}^{\mathrm{pi}} \leq \min \left\{\bar{\imath}_{t} \cdot Z_{t}^{\mathrm{pi}}, \sum_{h \in \mathcal{H}} \Delta \cdot i_{t}^{\mathrm{r}} \cdot f_{t}^{\mathrm{pi}} \cdot f_{t h}^{\mathrm{p}} \cdot f_{t}^{\mathrm{li}} \cdot X_{t h}^{\mathrm{rp}}\right\} \quad \forall t \in \mathcal{T} \\
& X_{t}^{\sigma} \leq \bar{\imath}_{t}^{\sigma}+M \cdot\left(1-Z_{t}^{\mathrm{pi}}\right) \quad \forall t \in \mathcal{T}
\end{aligned}
$$

Constraint (6a) calculates total production incentives, if available, for each technology. Constraint (6b) sets an upper bound on the size of system that qualifies for production incentives, if production incentives are available.

\subsection{Power Rating}

$$
\begin{aligned}
& X_{t}^{\sigma} \leq \bar{b}_{t}^{\sigma} \cdot \sum_{s \in \mathcal{S}_{t k}} Z_{t k s}^{\sigma \mathrm{s}} \quad \forall c \in \mathcal{C}, t \in \mathcal{T}_{c}, k \in \mathcal{K}_{t} \\
& \sum_{t \in \mathcal{T}_{c}, s \in \mathcal{S}_{t k}} Z_{t k s}^{\sigma \mathrm{s}} \leq 1 \quad \forall c \in \mathcal{C}, k \in \mathcal{K} \\
& \sum_{t \in \mathcal{T}_{c}} X_{t}^{\sigma} \geq \underline{b}_{c}^{\sigma} \quad \forall c \in \mathcal{C} \\
& X_{t h}^{\mathrm{rp}}=X_{t}^{\sigma} \quad \forall t \in \mathcal{T}^{\mathrm{td}}, h \in \mathcal{H} \\
& X_{t h}^{\mathrm{rp}} \leq f_{t h}^{\mathrm{ed}} \cdot X_{t}^{\sigma} \quad \forall t \in \mathcal{T} \backslash \mathcal{T}^{\mathrm{td}}, h \in \mathcal{H} \\
& \underline{b}_{t k s}^{\sigma \mathrm{s}} \cdot Z_{t k s}^{\sigma \mathrm{s}} \leq X_{t k s}^{\sigma \mathrm{s}} \leq \bar{b}_{t k s}^{\sigma \mathrm{s}} \cdot Z_{t k s}^{\sigma \mathrm{s}} \quad \forall t \in \mathcal{T}, k \in \mathcal{K}_{t}, s \in \mathcal{S}_{t k} \\
& \sum_{s \in \mathcal{S}_{t k}} X_{t k s}^{\sigma \mathrm{s}}=X_{t}^{\sigma} \quad \forall t \in \mathcal{T}, k \in \mathcal{K}_{t}
\end{aligned}
$$

Constraint (7a) permits nonzero power ratings only for the selected technology and corresponding subdivision in each class. Constraint (7b) allows at most one technology to be chosen for each subdivision in each class. Constraint (7c) limits the power rating to the minimum allowed for a technology class. Constraint (7d) prevents renewable technologies from turning down; rather, they must provide output at their nameplate capacity. Constraint (7e) limits rated production from all non-renewable technologies to be less than or equal to the product of the power rating and the derate factor for each time period. Constraint (7f) imposes both lower and upper limits on power rating of a technology, allocated to a subdivision in a segment, and constraint $(7 \mathrm{~g})$ sums the segment sizes to the total for a given technology and subdivision. 


\subsection{Load Balancing and Grid Sales}

$$
\begin{aligned}
& \sum_{t \in \mathcal{T}^{\mathrm{e}}}\left(f_{t h}^{\mathrm{p}} \cdot f_{t}^{\mathrm{l}} \cdot X_{t h}^{\mathrm{rp}}\right)+\sum_{b \in \mathcal{B}^{\mathrm{e}}} X_{b h}^{\mathrm{dfs}}+\sum_{u \in \mathcal{U}^{\mathrm{p}}} X_{u h}^{\mathrm{g}}=\sum_{t \in \mathcal{T}^{\mathrm{e}}}\left(\sum_{b \in \mathcal{B}^{\mathrm{e}}} X_{b t h}^{\mathrm{pts}}+\sum_{u \in \mathcal{U}_{t}^{\mathrm{s}}} X_{t u h}^{\mathrm{ptg}}\right) \\
& +\sum_{u \in \mathcal{U}^{\mathrm{sb}}} X_{u h}^{\mathrm{stg}}+X_{h}^{\mathrm{gts}}+\sum_{t \in \mathcal{T}^{e c}} X_{t h}^{\mathrm{tp}} / \eta^{\mathrm{ec}}+\delta_{h}^{\mathrm{d}} \quad \forall h \in \mathcal{H}^{g} \\
& \sum_{t \in \mathcal{T}^{\mathrm{e}}}\left(f_{t h}^{\mathrm{p}} \cdot f_{t}^{\mathrm{l}} \cdot X_{t h}^{\mathrm{rp}}\right)+\sum_{b \in \mathcal{B}^{\mathrm{e}}} X_{b h}^{\mathrm{dfs}}=\sum_{b \in \mathcal{B}^{\mathrm{e}}}, t \in \mathcal{T}^{\mathrm{e}}\left(\mathcal{X}_{\lfloor\sqcup \zeta}^{\mathrm{pts}}+\sum_{\sqcap \in \mathcal{U}^{\mathrm{c}}} \mathcal{X}_{\sqcup \sqcap \backslash}^{\mathrm{ptg}}\right) \\
& +\sum_{t \in \mathcal{T}^{\mathrm{ec}}} X_{t h}^{\mathrm{tp}} / \eta^{\mathrm{ec}}+\delta_{h}^{\mathrm{d}} \quad \forall h \in \mathcal{H} \backslash \mathcal{H}^{g} \\
& \sum_{u \in \mathcal{U}^{\mathrm{p}}} X_{u h}^{\mathrm{g}} \geq X_{h}^{\mathrm{gts}} \forall h \in \mathcal{H}^{\mathrm{g}} \\
& \sum_{b \in \mathcal{B}^{\mathrm{e}}} X_{b h}^{\mathrm{dfs}} \geq \sum_{u \in \mathcal{U}^{\mathrm{sb}}} X_{u h}^{\mathrm{stg}} \forall h \in \mathcal{H}^{\mathrm{g}} \\
& \Delta \cdot \sum_{h \in \mathcal{H}^{\mathrm{g}}}\left(X_{u h}^{\mathrm{stg}}+\sum_{t \in \mathcal{T}_{u}} X_{t u h}^{\mathrm{ptg}}\right) \leq \bar{\delta}_{u}^{\mathrm{gs}} \quad \forall u \in \mathcal{U}^{\mathrm{sb}} \cap \mathcal{U}^{\mathrm{nm}} \\
& \Delta \cdot \sum_{h \in \mathcal{H}^{\mathrm{g}}, t \in \mathcal{T}_{u}} X_{t u h}^{\mathrm{ptg}} \leq \bar{\delta}_{u}^{\mathrm{gs}} \forall u \in \mathcal{U}^{\mathrm{nm}} \backslash \mathcal{U}^{\mathrm{sb}}
\end{aligned}
$$

Constraint (8a) balances load by requiring that the sum of power (i) produced, (ii) discharged from storage, and (iii) purchased from the grid is equal to the sum of (i) the power charged to storage, (ii) the power sold to the grid from in-house production or storage, (iii) the power charged to storage directly from the grid, (iv) any additional power consumed by the electric chiller (where this is an additional term relative to the original model $(\mathcal{R})$ ), and $(\mathrm{v})$ the electrical load on site. Constraint $(8 \mathrm{~b})$ provides an analogous load-balancing requirement for hours in which the site is disconnected from the grid due to an outage (and contains the same additional term relative to the original model $(\mathcal{R})$ ). Constraint $(8 \mathrm{c})$ restricts charging of storage from grid production to the grid power purchased for each hour. Similarly, constraint (8d) restricts the sales from the electrical storage system to its rate of discharge in each time period. Constraints (8e) and (8f) restrict the annual energy sold to the grid at net-metering rates; only one of these is implemented in each case according to user-specified options. While a collection of pre-specified technologies may contribute to net-metering rates in both cases, constraint (8e) allows storage to contribute to net-metering while constraint (8f) does not.

\subsection{Rate Tariff Constraints}

Net Metering

$$
\begin{aligned}
& \sum_{v \in \mathcal{V}} Z_{v}^{\mathrm{nmil}}=1 \\
& \sum_{t \in \mathcal{T}_{v}} f_{t}^{\mathrm{d}} \cdot X_{t}^{\sigma} \leq i_{v}^{\mathrm{n}} \cdot Z_{v}^{\mathrm{nmil}} \forall v \in \mathcal{V} \\
& \Delta \cdot \sum_{h \in \mathcal{H}^{\mathrm{g}}}\left(\sum_{u \in \mathcal{U}^{\mathrm{nm}}, t \in \mathcal{T}_{u}} X_{t u h}^{\mathrm{ptg}}+\sum_{u \in \mathcal{U}^{\mathrm{nm}} \cap \mathcal{U}^{\mathrm{sb}}} X_{u h}^{\mathrm{stg}}\right) \leq \Delta \cdot \sum_{u \in \mathcal{U}^{\mathrm{p}}, h \in \mathcal{H}^{g}} X_{u h}^{\mathrm{g}}
\end{aligned}
$$

Constraint (9a) limits the net metering to a single regime at a time. Constraint (9b) restricts the sum of the power rating of all technologies to be less than or equal to the net metering regime. Constraint (9c) ensures that energy sales at net-metering rates do not exceed the energy purchased from the grid. 
Monthly Total Demand Charges

$$
\begin{aligned}
& \Delta \cdot \sum_{h \in \mathcal{H}_{m}} X_{u h}^{\mathrm{g}} \leq \bar{\delta}_{u}^{\mathrm{tu}} \cdot Z_{m u}^{\mathrm{ut}} \quad \forall m \in \mathcal{M}, u \in \mathcal{U}^{\mathrm{p}} \\
& Z_{m u}^{\mathrm{ut}} \leq Z_{m, u-1}^{\mathrm{ut}} \quad \forall u \in \mathcal{U}^{\mathrm{p}}: u \geq 2, m \in \mathcal{M} \\
& \bar{\delta}_{u-1}^{\mathrm{tu}} \cdot Z_{m u}^{\mathrm{ut}} \leq \Delta \cdot \sum_{h \in \mathcal{H}_{m}} X_{u-1, h}^{\mathrm{g}} \forall u \in \mathcal{U}^{\mathrm{p}}: u \geq 2, m \in \mathcal{M}
\end{aligned}
$$

Constraint (10a) limits the quantity of electrical energy purchased from the grid in a given month from a specified pricing tier to the maximum available. Constraint (10b) forces pricing tiers to be charged in a specific order, and constraint (10c) forces one pricing tier's purchases to be at capacity if any charges are applied to the next tier.

Peak Power Demand Charges: Months

$$
\begin{aligned}
& X_{m n}^{\mathrm{dn}} \leq \bar{\delta}_{n}^{\mathrm{mt}} \cdot Z_{m n}^{\mathrm{dmt}} \quad \forall n \in \mathcal{N}, m \in \mathcal{M} \\
& Z_{m n}^{\mathrm{dmt}} \leq Z_{m, n-1}^{\mathrm{dmt}} \quad \forall n \in \mathcal{N}: n \geq 2, m \in \mathcal{M} \\
& \bar{\delta}_{n-1}^{\mathrm{mt}} \cdot Z_{m n}^{\mathrm{dmt}} \leq X_{m, n-1}^{\mathrm{dn}} \quad \forall n \in \mathcal{N}: n \geq 2, m \in \mathcal{M} \\
& \sum_{n \in \mathcal{N}} X_{m n}^{\mathrm{dn}} \geq \sum_{u \in \mathcal{U}^{\mathrm{p}}} X_{u h}^{\mathrm{g}} \quad \forall m \in \mathcal{M}, h \in \mathcal{H}_{m}
\end{aligned}
$$

Constraint (11a) limits the energy demand allocated to each tier to no more than the maximum demand allowed. Constraint (11b) forces monthly demand tiers to become active in a prespecified order. Constraint (11c) forces demand to be met in one tier before the next demand tier. Constraint (11d) defines the peak demand to be greater than or equal to all of the demands across the time horizon, where an equality is actually induced by the sense of the objective function. A user-defined option precludes CHP technology production from reducing peak demand; if selected, constraint (11d) becomes:

$$
\begin{array}{r}
\sum_{n \in \mathcal{N}} X_{m n}^{\mathrm{dn}} \geq \sum_{u \in \mathcal{U}^{\mathrm{P}}} X_{u h}^{\mathrm{g}}+\sum_{t \in \mathcal{T}^{\mathrm{CHP}}}\left(f_{t h}^{\mathrm{p}} \cdot f_{t}^{\mathrm{l}} \cdot X_{t h}^{\mathrm{rp}}-\sum_{b \in \mathcal{B}^{\mathrm{h}}} X_{b t h}^{\mathrm{pts}}-\sum_{u \in \mathcal{U}_{t}^{s}} X_{t u h}^{\mathrm{ptg}}\right) \\
\forall m \in \mathcal{M}, h \in \mathcal{H}_{m} .
\end{array}
$$

Peak Power Demand Charges: Time-of-Use Demand and Ratchet Charges

$$
\begin{aligned}
& X_{d e}^{\mathrm{de}} \leq \bar{\delta}_{e}^{\mathrm{t}} \cdot Z_{d e}^{\mathrm{dt}} \quad \forall e \in \mathcal{E}, d \in \mathcal{D} \\
& Z_{d e}^{\mathrm{dt}} \leq Z_{d, e-1}^{\mathrm{dt}} \quad \forall e \in \mathcal{E}: e \geq 2, d \in \mathcal{D} \\
& \bar{\delta}_{e-1}^{\mathrm{t}} \cdot Z_{d e}^{\mathrm{dt}} \leq X_{d, e-1}^{\mathrm{de}} \quad \forall e \in \mathcal{E}: e \geq 2, d \in \mathcal{D} \\
& \sum_{e \in \mathcal{E}} X_{d e}^{\mathrm{de}} \geq \max \left\{\sum_{u \in \mathcal{U}^{\mathrm{p}}} X_{u h}^{\mathrm{g}}, \delta^{\mathrm{lp}} \cdot X^{\mathrm{plb}}\right\} \quad \forall d \in \mathcal{D}, h \in \mathcal{H}_{d} \\
& X^{\mathrm{plb}} \geq \sum_{n \in \mathcal{N}} X_{m n}^{\mathrm{dn}} \quad \forall m \in \mathcal{M}^{\mathrm{lb}}
\end{aligned}
$$

Constraints (12a)-(12d) correspond to constraints (11a)-(11d), respectively, but pertain to a type of charge not related to monthly use, but rather to time of use within a month. These ratchet charges are implemented using constraints (12d). The charge applied for each time-of-use period is a linearizable function of the greater of the peak electrical demand during that period (as given by the first term on the right-hand side of (12d)) and a fraction of the peak demand that occurs over a collection of months (known as look-back months) during the year (as given by the second term on the right-hand side of (12d)). Constraint (12d) ensures the peak demand over the set of look-back months is no lower than the peak demand for each look-back 
month. In this way, charges are based not only on use in a given month, but also on a fraction of use over the last several months, and becomes relevant when this latter use is high relative to current use. If CHP technologies are not allowed to reduce peak demand, constraint (12d) becomes:

$$
\begin{aligned}
& \sum_{e \in \mathcal{E}} X_{d e}^{\mathrm{de}} \geq \sum_{u \in \mathcal{U}^{\mathrm{p}}} X_{u h}^{\mathrm{g}}+\sum_{t \in \mathcal{T}^{\mathrm{CHP}}}\left(f_{t h}^{\mathrm{p}} \cdot f_{t}^{\mathrm{l}} \cdot X_{t h}^{\mathrm{rp}}-\sum_{b \in \mathcal{B}^{\mathrm{h}}} X_{b t h}^{\mathrm{pts}}-\sum_{u \in \mathcal{U}_{t}^{s}} X_{t u h}^{\mathrm{ptg}}\right) \\
& \forall d \in \mathcal{D}, h \in \mathcal{H}_{d} .
\end{aligned}
$$

\subsection{Minimum Utility Charge}

$$
\begin{aligned}
& X^{\mathrm{mc}} \geq c^{\mathrm{amc}}-\underbrace{\left(\Delta \cdot \sum_{u \in \mathcal{U}^{\mathrm{p}}, h \in \mathcal{H}^{\mathrm{g}}} c_{u h}^{\mathrm{g}} \cdot X_{u h}^{\mathrm{g}}\right.}_{\text {Grid Energy Charges }}+\underbrace{\sum_{d \in \mathcal{D}, e \in \mathcal{E}} c_{d e}^{\mathrm{r}} \cdot X_{d e}^{\mathrm{de}}}_{\text {Time-of-Use Demand Charges }}+ \\
& \underbrace{\sum_{m \in \mathcal{M}, n \in \mathcal{N}} c_{m n}^{\mathrm{rm}} \cdot X_{m n}^{\mathrm{dn}}}_{\text {Monthly Demand Charges }}- \\
& \underbrace{\left.\Delta \cdot\left(\sum_{h \in \mathcal{H}^{g}}\left(\sum_{u \in \mathcal{U}^{\mathrm{sb}}} c_{u h}^{\mathrm{e}} \cdot X_{u h}^{\mathrm{stg}}+\sum_{t \in \mathcal{T}, u \in \mathcal{U}_{t}^{\mathrm{s}}} c_{u h}^{\mathrm{e}} \cdot X_{t u h}^{\mathrm{ptg}}\right)\right)\right)}_{\text {Energy Export Payment }}
\end{aligned}
$$

Constraint (13) enforces a minimum payment to the utility provider, which is a fixed constant less charges incurred from grid energy, time-of-use demand and monthly demand payments, plus sales from exports to the grid.

\subsection{Non-negativity}

$$
\begin{aligned}
& X^{\mathrm{plb}}, X^{\mathrm{mc}} \geq 0 \\
& X_{t}^{\sigma}, X_{t}^{\mathrm{pi}} \geq 0 \quad \forall t \in \mathcal{T} \\
& X_{t u h}^{\mathrm{ptg}} \geq 0 \quad \forall u \in \mathcal{U}, t \in \mathcal{T}_{u}, h \in \mathcal{H} \\
& X_{u h}^{\mathrm{stg}}, X_{u h}^{\mathrm{g}} \geq 0 \quad \forall u \in \mathcal{U}, h \in \mathcal{H} \\
& X_{d e}^{\mathrm{de}} \geq 0 \quad \forall d \in \mathcal{D}, e \in \mathcal{E} \\
& X_{m n}^{\mathrm{dn}} \geq 0 \quad \forall m \in \mathcal{M}, n \in \mathcal{N} \\
& X_{h}^{\mathrm{gts}} \geq 0 \quad h \in \mathcal{H} \\
& X_{b}^{\mathrm{bkW}}, X_{b}^{\mathrm{bkWh}} \geq 0 \quad b \in \mathcal{B} \\
& X_{t k s}^{\sigma \mathrm{s}} \geq 0 \quad \forall t \in \mathcal{T}, \quad k \in \mathcal{K}, s \in \mathcal{S}_{t k} \\
& X_{b t h}^{\mathrm{pts}} \geq 0 \quad \forall b \in \mathcal{B}, t \in \mathcal{T}, h \in \mathcal{H} \\
& X_{b h}^{\mathrm{se}}, X_{b h}^{\mathrm{dfs}} \geq 0 \quad \forall b \in \mathcal{B}, h \in \mathcal{H} \\
& X_{t h}^{\mathrm{rp}}, X_{t h}^{\mathrm{f}}, X_{t h}^{\mathrm{fb}}, X_{t h}^{\mathrm{tpb}}, X_{t h}^{\mathrm{tp}}, X_{t h}^{\mathrm{ptw}} \geq 0 \quad \forall t \in \mathcal{T}, h \in \mathcal{H}
\end{aligned}
$$


4.11. Integrality

$$
\begin{aligned}
& Z_{v}^{\text {nmil }} \in\{0,1\} \quad \forall v \in \mathcal{V} \\
& Z_{t k s}^{\sigma \mathrm{s}} \in\{0,1\} \quad \forall t \in \mathcal{T}, k \in \mathcal{K}, s \in \mathcal{S}_{t k} \\
& Z_{t}^{\text {pi }} \in\{0,1\} \quad \forall t \in \mathcal{T} \\
& Z_{t h}^{\text {to }} \in\{0,1\} \quad \forall t \in \mathcal{T}, h \in \mathcal{H} \\
& Z_{d e}^{\mathrm{dt}} \in\{0,1\} \quad \forall d \in \mathcal{D}, e \in \mathcal{E} \\
& Z_{m n}^{\mathrm{dmt}} \in\{0,1\} \quad \forall m \in \mathcal{M}, n \in \mathcal{N} \\
& Z_{m u}^{\mathrm{ut}} \in\{0,1\} \quad \forall m \in \mathcal{M}, u \in \mathcal{U}
\end{aligned}
$$

Finally, constraints (14) ensure all of the variables in our formulation assume non-negative values. In addition to non-negativity restrictions, constraints (15) establish the integrality of the appropriate variables. 